\title{
INCIDÊNCIA E CONTROLE DE VIROSES EM ORQUÍDEAS NO ESTADO DE SÃO PAULO
}

\section{JULIANA CRAVEIRO DE FREITAS}

Engenheira Agrônoma

Orientador: Prof. Dr. JORGE ALBERTO MARQUES REZENDE

Dissertação apresentada à Escola Superior de Agricultura "Luiz de Queiroz", da Universidade de São Paulo, para obtenção do título de Mestre em Agronomia, Área de Concentração: Fitopatologia.

P I R A C I C A B A

Estado de São Paulo - Brasil

Setembro - 1996 
Dados Internacionais de Catalogação na Publicação (CIP)

DIVISÃo DE BIBLIOTECA E DOCUMENTAÇÃO - Campus "Luiz de Queiroz"/USP

\author{
Freitas, Juliana Craveiro de \\ Incidência e controle de viroses em orquideas no Estado de São Paulo / Juliana Craveiro \\ de Freitas. - Piracicaba, 1996. \\ 95p. : il. \\ Dissertaçāo (mestrado) - Escola Superior de Agricultura Luiz de Queiroz, 1996. \\ Bibliografia. \\ 1. Orquidea - Doença - Controle 2. Virus fitopatogènico 1. Titulo
}

CDD 635.93415 


\title{
INCIDÊNCIA E CONTROLE DE VIROSES EM ORQUIDEAS NO ESTADO DE SÃO PAULO
}

\author{
JULIANA CRAVEIRO DE FREITAS
}

Aprovada em: 30.10 .1996

Comissão Julgadora:

Prof. Dr. Jorge Alberto Marques Rezende

ESALQ/USP

Prof. Dr. Elliot Watanabe Kitajima

ESALQ/USP

Prof. Dr. Marcelo Agenor Pavan

UNESP - BOTUCATU

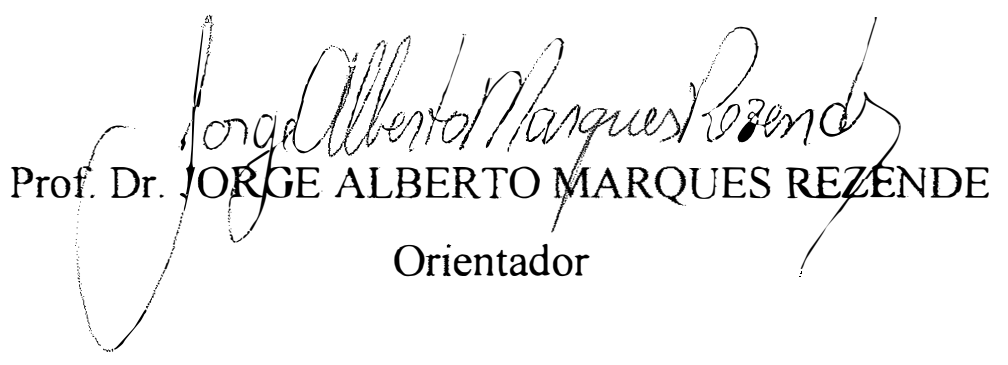


A meus pais, Eliane e Wilson, meus irmãos, Nuno e Guigo e meus avós Cidinha e Jurandir, pelo amor, compreensão e apoio ilimitados, 


\section{AGRADECIMENTOS}

Ao Prof. Jorge A. M. Rezende, não apenas pela orientação desta dissertação, mas também pelo incentivo e envolvimento neste trabalho, além da transmissão de valores éticos, de organização e dedicação que procurarei cultivar durante toda minha vida profissional;

Ao Prof Elliot W. Kitajima, pelas proveitosas discussões sobre fitovírus, além dos trabalhos de microscopia eletrônica desta dissertação;

À técnica Fernanda Y. B. Groppo e ao estagiário César H. Kameoka, pelo valioso auxilio no laboratório de Virologia do Depto. de Fitopatologia da ESALQ e pela amizade que surgiu durante a elaboração deste estudo;

Ao Sr. Pedro C. Arthuso, pelo auxílio nos trabalhos desenvolvidos em casa de vegetacão do Depto. de Fitopatologia da ESALQ;

Aos professores e funcionários do Depto. de Fitopatologia da ESALQ, pelos ensinamentos, amizade e estímulo desde os tempos de graduação;

Aos colegas do curso de Mestrado em Fitopatologia da ESALQ, muitos dos quais grandes amigos, pelas valiosas conversas sobre fitopatologia e por participarem não apenas do meu desenvolvimento científico, mas também humano e pessoal. Agradeço em especial à amiga Sílvia R. Galleti que, trabalhando no mesmo laboratório, participou ativamente de todos os momentos deste trabalho;

Ao Prof Paulo Sodero Martins e aos funcionários Benedito Correia e Josué Lemos de Pontes, por facilitarem a utilização do Orquidário do Depto. de Genética da ESALQ; 
A Cássio Van den Berg, pela ajuda na revisão da nomenclatura e taxonomia de orquídeas;

À bibliotecária Kátia M. de Andrade Ferraz, pela revisão da bibliografia desta dissertação, e pela amizade de muitos anos;

A Andrés Enrique Lai Reyes do CIAGRI por, sempre com muita boa vontade e paciência, auxiliar no preparo de slides para apresentações;

A Miyoko e Nobuyuki Hiranaka pela contribuição e incentivo a este trabalho, permitindo o uso do laboratório de cultura de tecidos, e à técnica Sayuri Komura pelo auxílio no referido laboratório;

Ao Prof. Dr. F.W. Zettler, da University of Florida, U.S.A., pela cessão de antissoros e pelo estímulo a este estudo;

Ao Prof. Dr. A. Brunt, do Horticultural Research International, U.K., por ter concedido o antissoro para o CyRSV;

À U.C.I. Farma, pelo fornecimento do virazole;

Ao Conselho Nacional de Desenvolvimento Científico e Tecnológico (CNPq), pela concessão de bolsa de estudos para a execução desta dissertação;

À Fundação de Amparo à Pesquisa do Estado de São Paulo (FAPESP), Proc. 94/3031-1, pelo apoio financeiro para a realização deste estudo;

Finalmente, agradeço à minha família, ao Gustavo e aos amigos que, mesmo distantes, souberam se fazer presentes em todos os momentos e compreender a necessidade de minha ausência. 


\section{SUMÁRIO}

Página

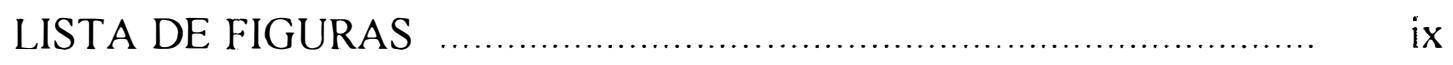

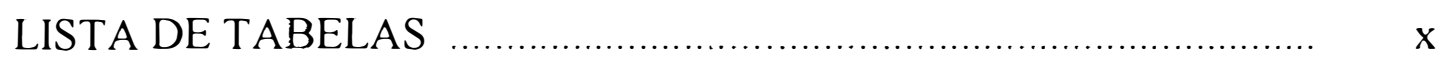

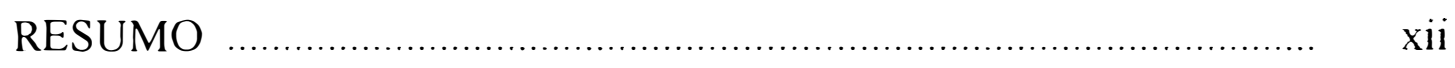

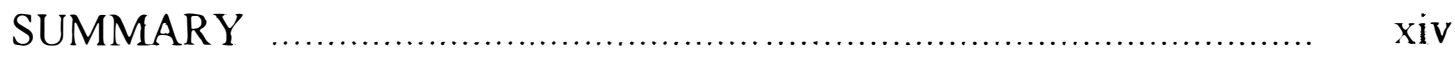

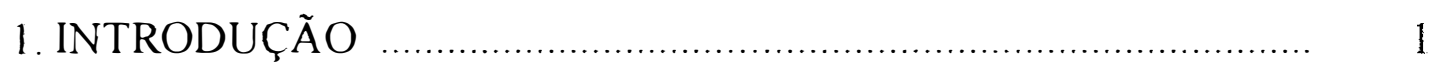

2. REVISÃO DE LITERATURA …................................................

2.1. Generalidades sobre as viroses em orquideas ........................... 3

2.2. Incidência de viroses em orquídeas ……................................. 8

2.3. Controle de viroses em orquídeas …..................................... 10

2.3.1. Uso de material propagativo livre de virus ...................... 10

2.3.2. Práticas culturais ........................................................ 16

3. MATERIAL E MÉTODOS ….................................................... 18

3.1. Obtenção de plantas indicadoras de virus de orquideas ……...... 18

3.2. Técnicas utilizadas na deteç̧ão e identificação dos virus ........... 19

3.2.1. Avaliação dos sintomas ................................................. 19

3.2.2. Teste de ELISA ........................................................... 19

3.2.3. Indexação biológica ……….......................................... 22

3.2.3. Microscopia eletrônica ……......................................... 22

3.3. Avaliação da incidência de viroses em orquídeas ........................ 24

3.3.1. Locais das avaliações ……........................................... 24

3.3.2. Plantas amostradas ..................................................... 24

3.3.3. Número e coleta de amostras ........................................ 25

3.3.4 Efeito da idade das plantas na incidencia de viroses ......... 25

3.4. Obtenção de matrizes livres de vírus ……………………........... 26

3.4.1. Escolha da planta ...................................................... 26 


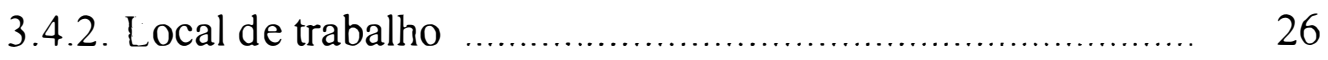

3.4.3. Preparo dos meios de cultivo …………....................... 27

3.4.3.1. Para meristemas ................................................. 27

3.4.3.2. Para PLB e plântulas _......................................... 27

3.4.4. Adição de virazole aos meios de cultivo ......................... 30

3.4.5. Desinfestação superfícial dos pseudobulbos ……............. $\quad 30$

3.4.6. Retirada dos meristemas ............................................. 33

3.4.7. Inoculação e cultivo dos meristemas ……......................... 33

3.4.8. Transplante e aclimatação das plântulas ………………... $\quad 35$

3.4.9. Indexação das plantas "ex vitro" ...................................... 35

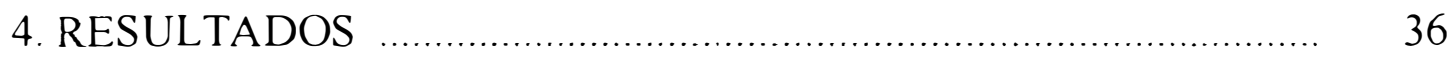

4.1. Identificação dos vírus …….................................................. 36

4.1.1. Com base nos sintomas .............................................. 36

4.1.2. Por meio do teste de ELISA ……................................. 44

4.1.3. Por meio do teste biológico ............................................. 44

4.1.4. Através de exames de microscopia eletrônica .................. 44

4.2. Incidência de viroses …..................................................... 47

4.2.1. Em orquidários particulares ……................................ 47

4.2.2. No orquidário da ESALQ/USP …................................ 51

4.3. Obtenção de Cymbidium Ayako Tanaka 'Hinodezuru' livre do

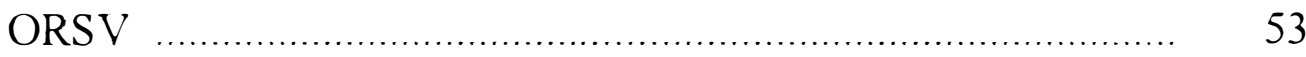

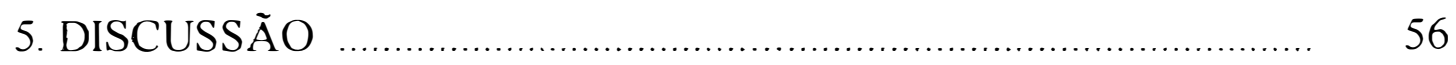

5.1. Diagnóstico de viroses em orquideas ……….......................... 56

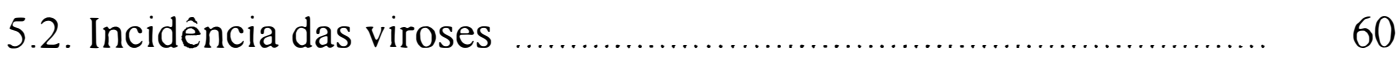

5.3. Controle das viroses em orquídeas …….................................. 64

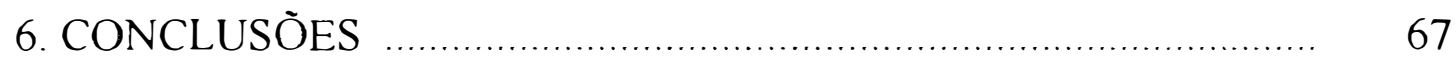


REFERENNCIAS BIBLIOGRÁFICAS

APENDICE 1 - Incidència de vírus em plantas provenientes de orquidários particulares do Estado de São Paulo

APENDICE 2 - Incidència de virus em plantas provenientes do orquidário de coleção da ESALQ/USP 


\section{LISTA DE FIGURAS}

Página

1. Região meristemática com cerca de $1 \mathrm{~mm}$ recém retirada de pseudobulbo de Cymbidium

2. Fases do desenvolvimento de explante de Cymbidium: meristema, PLB e plântula

3. Necrose em folha e início de necrose floral em Cattleya infectada pelo CyMV

4. Mosaico amarelo em faixas provocado pelo ORSV em Cymbidium ...

5. Lesões necróticas em folhas de Dendrobium associadas com o CyMV

6. Manchas necróticas causadas por CyMV em folha de Laelia

7. Mosaico acompanhado de necrose em Oncidium infectado com o CyMV

8. Folha "tachada" de Phalaenopsis infectado com ORSV + CyMV

9. Aspecto de corte ultrafino de tecido de Oncidium (A) e Cymbidium (B) com partículas e inclusões ("roda de bicicleta") típicas de "Orchid fleck-type virus")

10. Micrografia de Phaius (A) e Xylobium (B) com partículas de "Citrus leprosis-type virus" 


\section{LISTA DE TABELAS}

Página

1. Composição do meio de cultivo utilizado para o desenvolvimento de meristemas de Cymbidium Ayako Tanaka 'Hinodezuru'

2. Composição do meio de cultivo para PLBs e plântulas de Cymbidium Ayako Tanaka 'Hinodezuru'

3. Relação dos tratamentos de acordo com o tipo de meio de cultura, concentração do virazole e forma como este foi adicionado ao meio...

4. Associação entre a presença ou ausência de sintomas e a infecção com o ORSV, o CyMV ou o complexo viral ORSV + CyMV em diferentes gêneros de orquideas

5. Resultados de exames de cortes ultrafinos para a detecção de partículas virais em tecidos de diferentes gêneros de orquideas observados em microscópio eletrônico de transmissão

6. Incidência do ORSV, do CyMV e do complexo ORSV + CyMV em gêneros e híbridos de orquideas de cultivos particulares de 16 municípios do Estado de São Paulo

7. Incidência do ORSV, do CyMV ou do complexo viral ORSV + CyMV em função da idade das plantas do gênero Cymbidium

8. Incidência do ORSV, do CyMV ou do complexo viral ORSV + CyMV em função da idade das plantas do gênero Phalaenopsis

9. Incidência do ORSV, do CyMV e do complexo ORSV + CyMV em gêneros e hibridos de orquideas provenientes do orquidário da ESALQ/USP 
10. Indexação de plantas de Cymbidium Ayako Tanaka 'Hinodezuru', micropropagadas em meios de cultivo com e sem virazole, para a detecção do ORSV 


\title{
INCIDÊNCIA E CONTROLE DE VIROSES EM ORQUÚDEAS NO ESTADO DE SÃO PAULO
}

\author{
Autora: JULIANA CRA VEIRO DE FREITAS \\ Orientador: PROF. DR. JORGE ALBERTO MARQUES REZENDE
}

\section{RESUMO}

Os virus estão entre os principais problemas sanitários das orquideas. Apesar de alguns deles terem sido relatados no Brasil, pouco se sabe sobre quais os principais vírus que ocorrem em nossas condições, quais suas incidências e quais as alternativas para seu controle.

Em função disso realizou-se o presente trabalho, que teve como objetivo esclarecer as indagações acima. Assim, foram avaliadas amostras de diferentes gêneros de orquideas da coleção da ESALQ/USP e de cultivos particulares de 16 municípios do Estado de São Paulo. Um total de 1773 plantas (315 do orquidário da ESALQ e 1458 de cultivos particulares), foram testadas através de PTA-ELISA para a presença do vírus da mancha anelar do odontoglossum (“Odontogossum ringspot virus" - ORSV), do virus do mosaico do cymbidium ("Cymbidium mosaic virus" - CyMV), do virus do mosaico do pepino ("Cucumer mosaic virus" - CMV), do virus da mancha anelar do cymbidium ("Cymbidium ringspot virus" - CyRSV) e do "Vanila mosaic virus" - VMV, este último 
indexado a partir de antissoro contra um potyvirus relacionado, o vírus do mosaico do inhame ("Dasheen mosaic virus" - DsMV).

O ORSV e o CyMV foram os vírus preponderantes encontrados infectando orquídeas no Estado, com médias de incidência em torno de 10\%. Algumas plantas de Cymbidium, Miltonia, Oncidium, Phaius e Xylobium mostraram-se infectadas por um rhabdovirus ainda não totalmente caracterizado. Nenhuma das amostras mostrou-se infectada com o CMV, o CyRSV ou o DsMV.

A elevada incidência de plantas naturalmente sadias que ocorrem nas áreas de cultivo mostram que a obtenção de matrizes livres de vírus pode ser conseguida facilmente, desde que sejam realizados testes de indexação do material vegetal. Para o caso de espécies ou variedades de grande interesse e que se encontrem $100 \%$ infectadas por vírus, verificou-se que a eliminação deste pode ser conseguida através da associação entre o cultivo de meristemas e a quimioterapia, conforme observado na variedade de Cymbidium Ayako Tanaka 'Hinodezuru' infectada pelo ORSV. O quimioterápico testado foi o virazole, tendo sido introduzido ao meio de cultivo de meristemas nas concentrações de 15, 20 e 25 ppm ou aos meios de subcultivo nas concentrações de 20 , 25 ou $30 \mathrm{ppm}$. Apesar de quase todos os tratamentos terem sido efetivos, as maiores porcentagens de plantas sadias foram obtidas quando o virazole era adicionado aos meios de subcultivo. O tratamento contendo $30 \mathrm{ppm}$ de virazole filtrado nos meios de subcultivo permitiu a regeneração de $100 \%$ de Cymbidium livres de vírus. 
INCIDENCE AND CONTROL OF ORCHID VIRUSES IN THE STATE OF SÃO PAULO, BRAZIL

\author{
Author: JULIANA CRAVEIRO DE FREITAS \\ Advisor: PROF. DR. JORGE ALBERTO MARQUES REZENDE
}

\title{
SUMMARY
}

Viruses are one of the main problems of orchids troughtout the world. Although some of them have already been reported in Brazil, very little is known about which are the prevalent, their incidences and the best strategies for their control.

The present work was carried out with the purpose to answer some of these questions. Plants from different species and varieties of orchids from the orchid collection at the Escola Superior de Agricultura "Luiz de Queiroz"/Universidade de São Paulo, Piracicaba, SP (ESALQ/USP) and from private productions from 16 localities in the State of São Paulo were surveyed. A total of 1773 plants (315 from the ESALQ collection and 1458 from commercial productions), were tested by PTA-ELISA with antisera against the following viruses: Odontoglossum ringspot virus (ORSV), Cymbidium mosaic virus (CyMV), Cucumber mosaic virus (CMV), Cymbidium ringspot virus (CyRSV) and Vanila mosaic virus (VMV). For the last virus, VMV, it was 
used the antiserum against Dasheen mosaic virus (DsMV), since these two viruses are closely related.

ORSV and CyMV were found to be the most important viruses infecting orchids in the State with an average incidence around $10 \%$. In a few plants of Cymbidium, Miltonia, Oncidium, Phaius and Xylobium, there were also found particles of a rhabdovirus, not yet characterized. None of the samples were infected with CMV, CyRSV and DsMV.

The high incidence of naturally virus-free plants occurring in the production areas shows that virus-free stock plants are not difficult to obtain, since the plants are properly indexed. However, if any particular high value species or variety is $100 \%$ infected by a virus, its elimination can be obtained by means of the association between meristem tip culture and chemotherapy, as it was demonstrated to Cymbidium Ayako Tanaka 'Hinodezuru' infected with ORSV. The chemotherapeutic agent tested was the virazole and it was added to the meristem culture medium at concentration of 15,20 and $25 \mathrm{ppm}$ or to subcultures media at 20,25 and $30 \mathrm{ppm}$. Although almost all treatments were effective, the highest porcentage of virus-free plants were obtained when the virazole was added to the subculture media. Treatment containing $30 \mathrm{ppm}$ of virazole filtered to the subcultures media gave $100 \%$ of virus-free Cymbidium. 


\section{INTRODUÇÃO}

A família Orchidaceae é considerada a mais numerosa de todo o reino vegetal, com mais de 800 gêneros, 25.000 espécies e uma infinidade de híbridos (Sheehan, 1980). O elevado número de espécies e híbridos possibilita a ocorrência de grande variabilidade de formas, tamanhos e cores de folhas e de flores, o que torna essas plantas de grande importância econômica e faz com que sejam produzidas em todo o mundo, sempre com grande aceitação no mercado de flores de vaso e de corte.

Alguns gêneros com elevado valor econômico como Cattleya, Laelia, Miltonia e Oncidium são nativos do Brasil, entre outros países (Silva, 1986) e são apreciados nos mercados brasileiro e internacional, evidenciando a potencialidade do país no cultivo de orquideas.

Por se tratarem de plantas ornamentais, as orquidáceas devem apresentar folhas e flores de boa qualidade, o que implica, entre outros fatores, na ausência de pragas e patógenos. Dentre os principais patógenos que infectam orquideas estão os vírus, os quais além de depreciarem quantitativa e qualitativamente as plantas, também apresentam dificuldades de controle (Sheehan, 1980; Bicalho, 1992; Batchelor, 1993). 
Os principais vírus que infectam orquídeas em todo o mundo são os da mancha anelar do odontoglossum ("Odontoglossum ringspot virus" - ORSV) e do mosaico do cymbidium ("Cymbidium mosaic virus" - CyMV), embora outros 25 já tenham sido relatados em plantas dessa família em diversos países (Lawson \& Hsu, 1995).

No Brasil, além do ORSV e do CyMV (Chagas et al., 1977), já foram detectados o vírus do mosaico do pepino ("Cucumber mosaic virus" - CMV) em Dendrobium nobile (Nóbrega, 1947) e partículas baciliformes do tipo rhabdovirus em inúmeras espécies de orquídeas (Kitajima et al., 1974; Chagas et al., 1988).

Apesar do elevado valor econômico das orquídeas para o país e dos prejuízos causados por doenças de origem viral, há escassez de estudos sobre a situação atual e de medidas satisfatórias de controle dessas viroses no Brasil. Com base nesses fatos, propôsse o presente trabalho, cujos principais objetivos foram:

1. Identificar os vírus que estão infectando as principais espécies e/ou híbridos de orquídeas no Estado de São Paulo;

2. Quantificar a incidência dos diferentes vírus em inúmeros gêneros de orquídeas de cultivos comerciais e de coleção no Estado e

3. Avaliar o efeito do virazole, combinado com o cultivo de meristemas "in vitro", para a obtenção de plantas de Cymbidium Ayako Tanaka 'Hinodezuru' livres de ORSV. 


\section{REVISĀO DE LITERATURA}

\subsection{Generalidades sobre as viroses em orquídeas}

São conhecidos pelo menos 27 vírus que infectam orquídeas (Lawson \& Hsu, 1995), embora a maioria ainda não esteja totalmente caracterizada. Dentre eles, o ORSV e o CyMV são os de maior incidência e importância econômica em todo o mundo (Zettler et al., 1990; Hu et al., 1993; Wong et al., 1994; Lawson \& Hsu, 1995).

O primeiro foi descrito por Jensen \& Gold (1951), e pertence ao gênero Tobamovirus. Apresenta partículas rígidas e alongadas com dimensões aproximadas de $300 \times 18 \mathrm{~nm}$. O CyMV, relatado pela primeira vez por Jensen (1951), pertence ao gênero Potexvirus. Suas partículas são filamentosas, flexuosas e medem ao redor de $475 \mathrm{x}$ $13 \mathrm{~nm}$.

Ambos não apresentam vetor conhecido (Francki, 1970; Namba \& Ishii, 1971; Paul, 1975; Kobayashi \& Kamemoto, 1989) e não parecem ser transmitidos pelas sementes de plantas infectadas (Jensen, 1951; 1955; Wisler et al., 1979; Zettler et al., 1987), embora Hamilton \& Valentine (1984) tenham observado a presença de partículas

do ORSV e do CyMV em pólen de orquídeas infectadas com esses dois vírus e Yuen et 
al. (1979) tenham relatado que entre 123 plantas de Dendrobium obtidas por sementes de plantas infectadas com o CyMV, uma mostrou-se doente.

Tanto o ORSV quanto o CyMV são extremamente estáveis (Chia et al., 1992), ocorrem em altas concentrações nos tecidos das plantas infectadas (Kobayashi \& Kamemoto, 1989), são perpetuados através de propagação vegetativa (Wisler et al., 1986; González-Segñana, 1989) e facilmente transmitidos por instrumentos de corte utilizados na retirada do excesso de raizes, na desbrota e na colheita das inflorescências (Ko, 1985; Chia et al., 1992). Eventualmente esses vírus são ainda disseminados através de vasos ou solos contaminados (Lesemann ${ }^{1}$; Lawson, 1995).

É importante mencionar que os avanços na utilização de técnicas de cultivo de tecidos "in vitro" têm contribuido de maneira significativa para a perpetuação e distribuição de virus de orquídeas em praticamente todo o mundo. Já na década de 70, Lawson \& Hearon (1973) e Clifford (1977) chamaram a atenção para a disseminação dos principais vírus de orquídeas através da propagação clonal de plantas contaminadas em laboratórios de cultura de tecidos. Mais recentemente, vários pesquisadores (Wisler, 1989; Zettler et al., 1990; Chia et al., 1992; Lawson, 1995) enfatizaram que, ironicamente, orquideas infectadas com vírus foram produzidas em larga escala e distribuidas para viveiros em diversos locais. O mesmo foi observado por Freitas \& Rezende $^{2}$ em produção de orquídeas do gênero Cymbidium, no município de Atibaia, SP, mostrando que esse fato também ocorre em laboratórios comerciais no Brasil.

\footnotetext{
${ }^{1}$ LESEMANN, D.E. Virus diseases of orchids and some problems with control measures. Trabalho apresentado in: $2^{\text {nd }}$ SOUTHEAST ASIAN SYMPOSIUM ON PLANT DISEASES IN THE TROPICS, Bangkok, 1980.

${ }^{2}$ FREITAS, J.C.; REZENDE, J.A.M (Escola Superior de Agricultura "Luiz de Queiroz", Depto. de Fitopatologia, Piracicaba, SP). Constatação de campo, 1994.
} 
Além da perpetuação do ORSV e do CyMV através da micropropagação propriamente dita, a disseminação de vírus "in vitro" pode se dar ainda por intermédio dos instrumentos de corte como escalpelos e lâminas ou até mesmo através do meio de cultivo. Lesemann ${ }^{3}$ observou que no meio de cultivo onde se encontravam explantes de Cattleya contaminados com o CyMV havia grande concentração do vírus; o que sugere que explantes ou plântulas sadias que se encontrem adjacentes a material infectado podem ser contaminadas pelo vírus presente no ágar.

Embora o ORSV e o CyMV sejam considerados os mais importantes na cultura, outros vírus também podem causar danos em orquídeas. É o caso de algumas espécies do gênero Potyvirus, como "Vanilla mosaic virus" - VMV, que chega a causar danos severos em produções comerciais de Vanilla na Polinésia Francesa (Wisler, 1987a); o "Dendrobium mosaic virus" - DeMV, observado no Havaí (Hu et al., 1995); um isolado do "Bean yellow mosaic virus" - BYMV, encontrado no Japão, na Alemanha e nos Estados Unidos (Hammond \& Lawson, 1988) e o "Tumip mosaic virus" - TuMV, constatado na Alemanha e nos Estados Unidos (Lesemann \& Vetten ${ }^{4}$, citados por Lawson, 1995).

O CMV também já foi encontrado infectando plantas dessa família no Brasil (Nóbrega, 1947), no Japão (Inouye, 1969), na Coréia (Chang, 1987) e nos Estados Unidos (Ko, 1985; Freitas et al., 1995), embora não haja relatos sobre danos causados à cultura.

Um caso bastante específico é o do "Tomato spotted wilt virus" - TSWV, uma espécie do gênero Tospovirus que foi encontrado, em baixa incidência, em orquídeas

\footnotetext{
${ }^{3}$ LESEMANN, D.E. Op. cit., p. 4

${ }^{4}$ LESEMANN, D.E.; VETTEN, H.J. The occurrence of tobacco ratle and turnip mosaic viruses in Orchis sp., and of an unidentified potyvirus in Cypripedium calceolus. Acta Horticulturae, v. 164, p.45-54, 1985
} 
cultivadas próximas as áreas de crisântemos severamente infectados no Havaí (Hu et al., 1992).

Outro vírus que parece ter ocorrência bastante restrita é o vírus da mancha anelar do cymbidium ("Cymbidium ringspot virus" - CyRSV), uma espécie do gênero Tombusvirus, que também infecta plantas de trevo branco (Trifolium repens), e que foi encontrado na Inglaterra (Holings et al., 1977).

Partículas do tipo rhabdovirus, relacionadas com sintomas de manchas anelares bem definidas em folhas, têm sido observadas em inúmeros gêneros da família orquidácea, em diversos países (Lawson \& Hsu, 1995). Esses autores citam que foram relatados cinco rhabdovirus diferentes, do tipo denominado "small rhabdovirus-type viruses", com dimensões em torno de 40 a 50 nm x 100 a 120 nm, no Japão, na Nova Guiné, na Alemanha, nos Estados Unidos, no Brasil e na Dinamarca. Outros quatro rhabdovirus, apresentando partículas grandes ("large rhabdovirus-type viruses"), com 80 a $85 \mathrm{~nm}$ x 180 a $320 \mathrm{~nm}$ de dimensão, foram encontrados no Havaí e na Alemanha.

Zettler et al. (1987) comentam que dentre os 23 vírus relatados em orquídeas até aquele momento, 18 estão em gêneros com membros tipicamente transmitidos por artrópodos e 2 em gêneros transmitidos por nematóides. Os 3 restantes, CyMV, ORSV e CyRSV, não apresentam vetores conhecidos. Seis vírus, entre aqueles transmitidos por artrópodos, apresentam afídeos como vetores. São eles o "Clover yellow vein virus" CYVV, o DeMV, o CMV, o BYMV, o VMV e o TuMV. Outros dois vírus relatados recentemente, o TSWV no Havaí (Hu et al., 1992) e o "Impatiens necrotic spot virus" - 
INSV na Califórnia (Mayhew et al., 1992) também são transmitidos por artrópodos, apresentando como vetores os tripes (Lawson, 1995).

Os danos causados por vírus em orquideas são devidos à depreciação das plantas que, muitas vezes, manifestam a doença através da diminuição na produção e/ou qualidade das folhas e flores (Okemura et al., 1984). Devido à grande diversidade genética que apresentam, as orquideas expressam muita variabilidade nos sintomas provocados pelos vírus (Sheehan, 1980; Wisler, 1989; Lawson, 1995; Lawson \& Hsu, 1995). Assim, as plantas infectadas podem estar assintomáticas ou apresentar leve clorose, mosaico nas folhas e pequena redução no número e tamanho de flores (Hu \& Ferreira, 1994). Podem ainda mostrar sintomas severos de manchas anelares ou irregulares, cloróticas ou necróticas nas folhas, "color-break" (descontinuidade da coloração natural das pétalas e sépalas) ou necrose nas flores, além de deformação floral e aborto dos botões florais, impossibilitando sua comercialização (Person \& Cole, 1986; Kobayashi \& Kamemoto, 1989; Zettler et al., 1990).

Aparentemente não se sabe ainda porque alguns clones permanecem assintomáticos, enquanto outros expressam sintomas severos. Sabe-se, no entanto, que os sintomas podem se manifestar de modo bastante variável em função de diferentes fatores como as condições ambientais, a idade do tecido vegetal, o gênero ou a variedade da planta, entre outros (Lesemann ${ }^{5}$; Wisler, 1981; Wisler et al., 1987a; Wong et al., 1994; Lawson, 1995). Tal caracteristica dificulta significativamente a detecção e identificação de virus em orquideas com base apenas nos sintomas e justifica a necessidade de um programa de indexação especialmente de plantas assintomáticas na produção (Wisler,

\footnotetext{
${ }^{5}$ LESEMANN, D.E. Op. cit., p. 4
} 
1989). Estas podem facilmente servir como introdutoras de vírus em áreas ainda isentas de viroses.

\subsection{Incidência de viroses em orquídeas}

Inúmeros trabalhos foram conduzidos a fim de se identificar quais os principais vírus que infectam orquídeas e quais suas incidências em diversas regiões do mundo, com ênfase ao ORSV e ao CyMV. Um dos primeiros trabalhos dessa natureza foi desenvolvido em Porto Rico por Pérez \& Cortés-Monllor (1960). Trabalhos semelhantes foram posteriormente realizados nos Estados Unidos (Zettler et al., 1978; Bodnaruk et al., 1979; Wisler, 1981; Okemura et al., 1984; Hu et al., 1993), em alguns países da América Latina, da Ásia e da África (Wisler et al., 1979), em Taiwan (Inouye \& Leu, 1983), na Polinésia Francesa (Wisler et al., 1987b), no Brasil (González-Segnaña, 1989) e em Cingapura (Wong et al. 1994). Os resultados, geralmente parecidos, quase sempre mostram uma alta incidência do ORSV e do CyMV, isoladamente ou em conjunto, sendo mais preponderante o CyMV.

Alguns estudos tiveram como objetivo investigar a incidência do ORSV e do CyMV em orquídeas no seu habitat natural, porém em nenhum caso foi relatada a ocorrência de plantas infectadas (Zettler et al., 1978; Bodnaruk et al., 1979; Wisler et al., 1979; Wisler et al. 1983). 
Poucos trabalhos foram realizados para se conhecer a incidência de outros vírus que possam infectar orquídeas. Wisler et al. (1987b) se propuseram a testar plantas para a presença do VMV em Vanilla na Polinésia Francesa e encontraram incidências de até $21,7 \%$ em alguns cultivos comerciais. Hu et al. (1993) testaram 331 amostras para o TSWV e um potyvirus no Havai, porém apenas uma planta mostrou-se infectada com cada um desses vírus. Inouye \& Leu (1983), avaliaram 124 plantas para a presença do CMV e do rhabdovirus "Orchid fleck virus" - OFV e observaram que apenas 5 delas estavam infectadas com o CMV e 2 com o OFV. Apesar do CMV ocorrer geralmente em baixa incidência em cultivos de orquídeas, Freitas et al. (1995) verificaram que 31,5\% das plantas examinadas de uma antiga coleção da Sociedade Americana de Orquidófilos, na Flórida, estavam infectadas por esse vírus.

Outros vírus relatados na cultura, nunca ou raramente são incluídos em levantamentos de viroses em orquideas. O closterovirus "Dendrobium vein necrosis virus" - DVNV, relatado na Alemanha e nos Estados Unidos por Lesemann (1977) e Elliott et al. (1987) respectivamente, é um exemplo, uma vez que aparentemente nunca foi realizado estudo sobre a sua incidência em cultivos dessa ornamental. Outro exemplo é o CyRSV, que apesar de ter sido relatado há muitos anos na Inglaterra (Hollings et al., 1977), avaliação mais recente de sua presença em orquidários só se deu em trabalho realizado por Freitas et al. (1995) na Flórida, E.U.A. Esses autores analisaram 95 plantas de diferentes gêneros e espécies de orquídeas cultivadas, porém em nenhuma delas foi detectada a presença desse vírus. 


\subsection{Controle de viroses em orquídeas}

\subsubsection{Uso de material propagativo livre de vírus}

Lawson \& Hsu (1995) afirmam que a produção de orquídeas livres de vírus é fácil para colecionadores ou produtores iniciantes, desde que selecionem plantas sadias para o início do cultivo. Os autores comentam ainda sobre a necessidade de se indexarem as orquídeas para a presença desses patógenos e sugerem que, ao se introduzir plantas novas no orquidário, estas devem permanecer separadas das demais até que se realizem testes que permitam comprovar a sanidade das mesmas. Tanto cuidado é justificado pela dificuldade de manter as plantas sadias após a introdução de um ou mais vírus na área.

Além da utilização de plantas comprovadamente livres de vírus em cultivos iniciais, o mesmo deve ser almejado em cultivos antigos. Praticamente todos os trabalhos realizados acerca de levantamento de viroses em orquídeas mostram que, apesar da incidência de vírus ser relativamente elevada, normalmente há plantas que se encontram sadias nas áreas de produção. Tais plantas, uma vez identificadas, podem ser multiplicadas e utilizadas como matrizes livres de vírus, sem que haja a necessidade de se fazer qualquer tratamento adicional.

No entanto, quando há necessidade de se multiplicar uma planta de grande interesse e esta se encontra infectada por vírus, ou ainda quando uma variedade apresenta $100 \%$ de suas plantas contaminadas, algumas técnicas podem ser utilizadas para a obtenção de material isento do patógeno. Os principais métodos utilizados para a limpeza 
de vírus em plantas são a termoterapia, a cultura de tecidos e a quimioterapia, podendo ser empregados isoladamente ou em conjunto. Para a eliminação de vírus em orquídeas, normalmente utiliza-se a técnica de cultura de tecidos, isoladamente (Morel, 1960; Ishii, 1974) ou associada à quimioterapia (Albouye et al., 1988; Loi et al., 1991; Toussaint et al., 1993)

Porém, ao se trabalhar com a cultura de tecidos visando a obtenção de orquídeas livres de vírus, alguns aspectos devem ser levados em consideração, como a capacidade de propagação "in vitro" do gênero escolhido. Alguns autores comentam que gêneros de orquídea como Aranda e Vanda (Zettler et al., 1990) e Paphiopedilum (Pierik, 1987), são de difícil micropropagação, tornando essa técnica praticamente inviável. Outro aspecto de grande importância para o sucesso da limpeza de vírus é a escolha do tecido vegetal adequado, de preferência os meristemas de tecidos jovens e vigorosos, que provavelmente apresentarão menor concentração ou até ausência de partículas virais.

No caso das orquídeas, o trabalho pioneiro nesse sentido foi realizado por Morel (1960), que demonstrou ser possível a obtenção de plantas de Cymbidium livres do CyMV através da técnica de cultivo de meristemas. Apesar de os trabalhos iniciais de Morel terem animado pesquisadores e produtores de orquídeas, observou-se com o tempo que a obtenção de plantas livres de vírus por essa técnica nem sempre era possivel (Albouye et al., 1988; Loi et al., 1991; Toussaint et al., 1993). Percebeu-se ainda que o cultivo de meristemas só parecia eficaz para a eliminação do CyMV e não do ORSV (Inouye, 1984), e mesmo assim, vários fatores interferiam no sucesso de obtenção de plantas de alta sanidade (Ishii, 1974; Lesemann ${ }^{6}$ ).

\footnotetext{
${ }^{6}$ LESEMANN, D.E. Op. cit., p.4
} 
Ishii (1974), mostrou que o tamanho do meristema retirado era de extrema importância, não apenas para o desenvolvimento do tecido "in vitro", mas também para a eliminação do vírus. Utilizando explantes de Laeliocattleya contaminados com o ORSV e com o CyMV, com cerca de $1 \mathrm{~mm}$ de comprimento ou mais, verificou sobrevivência de $48 \%$ quando cultivados em meio de cultivo. A porcentagem de sobrevivência dos explantes diminuiu para $15 \%$ quando os pedaços de tecido eram pouco maiores do que $0,5 \mathrm{~mm}$ e era praticamente nula quando os meristemas retirados eram menores do que 0,5 mm. Num primeiro experimento o autor observou que todos os meristemas que sobreviveram continuaram infectados pelos dois vírus.

De acordo com Pierik (1987), a baixa sobrevivência de meristemas que efetivamente produzirão plantas livres de vírus se deve principalmente às perdas devido a infecção pelo próprio vírus, dano mecânico, ressecamento e oxidaçao do explante.

Uma vez que a oxidação de plantas de orquídeas, especialmente as do gênero (attleya e seus híbridos (Pierik, 1987), implica em grandes perdas de explantes muito pequenos, em alguns casos a regeneração de plantas só é possível quando se cortam porções maiores da região meristemática, que geralmente englobam primórdios foliares e células adjacentes. No caso de Cattleya, normalmente é cortado o broto inteiro, com 3 a $5 \mathrm{~mm}$ e com muitos primórdios foliares (Pierik, 1987). É conhecido entretanto, que as áreas adjacentes à região meristemática podem apresentar grande quantidade de partículas virais, o que pode justificar o alto índice de infecção viral mesmo em plantas submetidas a cultura de tecidos. 
Como aparentemente a incidência de vírus em plantas micropropagadas parece ser variável não apenas em relação ao tamanho do meristema, mas também ao gênero de orquídea, supõe-se que outros fatores, como a distribuição irregular do vírus nos tecidos meristemáticos e a anatomia dos meristemas de diferentes orquídeas podem estar associados a esse fato (Lawson \& Hearon, 1974).

Apesar da dificuldade de se obterem plantas de Laeliocattleya sadias através apenas da cultura de meristemas, Ishii (1974) observou que quando pedaços de regiões meristemáticas de mericlones de 4 plantas infectadas com o ORSV e o CyMV foram microenxertados em calos de orquideas, obtiveram-se 3 plantas livres do CyMV. Para o ORSV, entretanto, todos os 4 mericlones continuaram contaminados.

Na tentativa de se otimizar a obtenção de material livre de vírus através da cultura de tecidos de orquídeas, Inouye (1984) realizou um trabalho que associava a técnica de cultivo de meristema com o tratamento com antissoro contra o vírus a ser eliminado. $\mathrm{O}$ autor mostrou que pedaços diminutos de meristema $(0,1$ a $0,3 \mathrm{~mm})$ de Cymbidium infectados com o ORSV e o CyMV, quando imersos em antissoro para ORSV por 1 hora, regeneraram $52,9 \%$ de plantas sadias. Ainda de acordo com o autor, o CyMV foi facilmente eliminado de Cymbidium, mesmo sem a adição de antissoro específico, quando os meristemas retirados foram da ordem de 0,1 a $0,3 \mathrm{~mm}$ de comprimento. É importante mencionar que os meristemas retirados de plantas de Cymbidium não se oxidam tão facilmente "in vitro" como os de Cattleya e seus híbridos, possibilitando assim o cultivo de explantes de tamanhos diminutos. 
Outra forma de obtenção de material propagativo livre de vírus é através do cultivo de meristemas associado à quimioterapia. Baptista (1995) comenta que os estudos sobre quimioterapia antifitoviral tiveram início na década de 50 , porém foi a partir de 1970 que um grande número de trabalhos foi apresentado, principalmente devido ao aparecimento de novos produtos quimioterápicos sintéticos. Dentre esses, um dos mais estudados e que tem proporcionado melhores resultados práticos parece ser o virazole. Este é o nome comercial do ribavirin ou 1- $\beta$-D-ribofuranosyl-1,2,4-triazol-3-carboxamida que é um agente antiviral que não induz interferon e que tem um amplo espectro de atividade contra vírus de RNA ou de DNA que infectam homens, animais e plantas (Toussaint et al., 1993).

O produto, de acordo com Maugh (1976), é um agente antiviral no sentido estrito do termo, pois interfere diretamente na replicação dos vírus. Aparentemente o virazole inibe $a$ atividade da inosina monofosfato desidrogenase ("IMP dehydrogenase"), uma enzima chave para a formação de bases purínicas, especialmente guanosina (Streeter et al., 1973). Assim, o composto deve simular a guanosina, consequentemente reduzindo o suprimento de nucleotídeos derivados dessa base. De Clercq \& Luczak (1975) sugerem que a grande demanda para nucleotídeos requerida pela multiplicação viral não pode ser satisfeita na presença de concentração adequada de virazole, o que resulta numa diminuição significativa da replicação do vírus.

De acordo com Kluge \& Marcinka ${ }^{7}$, citados por De Fazio et al. (1980), o virazole é um dos compostos antifitovirais mais eficientes que se conhece. Experimentos com

\footnotetext{
${ }^{7}$ KLUGE, S; MARCINKA, K. The effects of polyacrylic acid and virazole on the replication and component formation of red clover mottle virus. Acta Virologica, v 23, p. 148-152, 1979
} 
plantas intactas mostraram que o virazole pode provocar certa diminuição na quantidade de virus, atrasando a infecção sistêmica (De Fazio et al., 1980), diminuindo o número de lesões locais (Silva \& Nogueira, 1983) ou minimizando a manifestação dos sintomas (Cheplick \& Agrios, 1983); porém não promove a eliminação do vírus do tecido vegetal (De Fazio et al., 1980; Cheplick \& Agrios, 1983; Silva et al., 1987). Devido a essa eficiência parcial do virazole quando aplicado em plantas intactas, tem-se dado preferência à utilização do quimioterápico "in vitro", adicionando-o ao meio de cultivo para tecidos vegetais.

A utilização de virazole associado com a cultura de tecidos, visando a obtenção de material propagativo livre de vírus, foi testada para diversas espécies vegetais, tais como batata (Cassells \& Long, 1982; Klein \& Livingston, 1983), fumo (Simpkins et al., 1981), limoeiro Galego (Baptista, 1995) e videira (Baptista, 1995), apresentando geralmente resultados satisfatórios.

Albouye et al. (1988) parecem ter sido os primeiros a utilizarem a associação do cultivo de meristemas com a quimioterapia para a obtenção de Cymbidium livres do ORSV e do CyMV, obtendo resultados positivos.

Posteriormente, Loi et al. (1991) e Toussaint et al. (1993) também obtiveram resultados satisfatórios na eliminação do ORSV de plantas de Dendrobium e Cymbidium, respectivamente. O único problema citado por Albouye et al. (1988) e Loi et al. (1991) parece ter sido o efeito citotóxico provocado pelo virazole, especialmente quando este era adicionado em doses elevadas ao meio de cultivo. 


\subsubsection{Práticas culturais}

Outra alternativa para o controle de viroses em orquídeas é através de práticas culturais adequadas. Como a principal forma de disseminação do ORSV e do CyMV dentro da produção é através de instrumentos de corte utilizados nas operações normais de cultivo, recomenda-se a desinfecção de tesouras, facas e estiletes. Apesar dessas medidas serem mais importantes para o controle do ORSV e do CyMV, elas também podem ser úteis no combate a outros vírus que infectam orquídeas.

Alguns autores, testando produtos como trifosfato de sódio, formalina, hipoclorito de sódio e hidróxido de sódio em diferentes concentrações, álcool etílico, leite e água com sabão, concluíram que a melhor opção para a eliminação total das partículas virais aderidas aos instrumentos de corte era através da imersão destes em uma solução de trifosfato de sódio $5 \%$ por 5 minutos (Pugsley, 1952; Inouye, 1968), em hipoclorito de sódio 1\% ou hidróxido de sódio 1\% (Hu et al., 1994). Outros autores (Freytag, 1965; Lawson, 1967) recomendam a utilização de uma faca aquecida ("hot knife") para tal finalidade. Lawson (1995) recomenda o aquecimento das ferramentas de corte em forno a $149^{\circ} \mathrm{C}$ por uma hora ou a flambagem desse material, desde que previamente embebido em álcool, por vários segundos, a fim de se eliminarem as partículas de vírus que possam estar presentes nas lâminas após o corte de uma planta infectada.

Inúmeros pesquisadores (Sproles, 1983; Wisler, 1989; Hu et al., 1993; Lawson, 1995) ressaltam ainda que para haver um controle eficiente das viroses de orquídeas, deve ser dada importância aos métodos de higienização, não apenas através da limpeza 
de instrumentos de corte, mas também das mãos dos funcionários, além da desinfecção de vasos, substratos, bancadas e separação de plantas infectadas das sadias.

Uma vez que diversos vírus já relatados em orquídeas apresentam vetores conhecidos, o controle de artrópodos como afídeos, tripes e ácaros é sempre uma prática recomendada. Deve-se também proceder a eliminação de plantas hospedeiras alternativas desses vetores e de alguns vírus que se encontram próximas às áreas de cultivo. 


\section{MATERIAL E MÉTODOS}

\subsection{Obtenção de plantas indicadoras de vírus de orquídeas}

Neste trabalho foram utilizadas principalmente as espécies Nicotiana tabacum L. 'Turkish NN' e Cassia occidentalis L., por serem as indicadoras mais utilizadas para a detecção do ORSV e do CyMV, respectivamente (Francki, 1970; Wisler, 1989; González-Segñana, 1989). As plantas-teste indicadoras foram preparadas através de semeaduras feitas a intervalos de 20 a 30 dias, proporcionando sempre a presença de plantas em tamanho adequado para serem inoculadas. As plantas foram obtidas em vasos de alumínio cheios de terra misturada com composto orgânico e adubo mineral, previamente preparado e autoclavado a $121^{\circ} \mathrm{C}$ por 2 horas e mantidas sob condição de casa de vegetação no Departamento de Fitopatologia da ESALQ/USP. Adubações periódicas com sulfato de amônia e aplicação de mevinphos e aldicarb, para o controle de pulgão e mosca branca, respectivamente, foram realizadas sempre que necessário.

As plantas indicadoras para os demais vírus testados só eram obtidas quando necessário. Para a deteç̧ão do CMV, do CyRSV e do vírus do mosaico do inhame ("Dasheen mosaic virus" - DsMV), foram inoculados Cucumis sativa L. (Francki et al., 
1979), Nicotiana benthamiana Domin. (Hollings et al., 1977) e Philodendron selloun L. (Kitajima et al., 1984), respectivamente.

\subsection{Técnicas utilizadas na detecção e identificação dos vírus}

\subsubsection{Avaliação dos sintomas}

Grande parte das plantas testadas no presente trabalho teve seus sintomas descritos e anotados. Dessa forma, pôde-se avaliar a relação entre a ocorrência de vírus e o tipo de sintomas visíveis nos principais gêneros de orquídeas.

\subsubsection{Teste de ELISA}

Para a indexação serológica das amostras foram utilizados antissoros contra o CyRSV, obtido do laboratório do Dr. Alan Brunt, do Horticultural Research International, U.K. e contra o CyMV, o ORSV, o CMV e o DsMV, provenientes do laboratório do Dr. F. William Zettler, da University of Florida, U.S.A. Uma vez que o DsMV já foi descrito no Brasil (Rodrigues et al., 1984; Chagas et al., 1993), e o antissoro contra esse potyvirus reage fortemente com o $\mathrm{VMV}$, com chance de serem vírus idènticos (Wisler et al., 1987b), foi feita a indexação de orquídeas utilizando-se antissoro contra o DsMV, visando a possível detecção do VMV nas amostras.

Amostras de plantas sabidamente infectadas com cada um dos 5 vírus testados, denominadas controles positivos, e amostras de plantas sadias, controles negativos, foram 
confirmadas através da associação de exames de microscopia eletrònica e teste biológico, no caso do ORSV e do CyMV; ou obtidas com o Dr. F. W. Zettler, para os demais vírus.

Uma observação em relação a esse teste é que os diferentes gêneros dessa família apresentam grande variação quanto ao grau de oxidação dos extratos vegetais, o que geralmente origina respostas bastante variadas dos controles negativos. Em função disso, todos os testes de ELISA realizados durante o presente trabalho constaram de vários controles negativos, representados por extratos de diferentes gêneros de orquídeas. Quando todas as amostras testadas pertenciam a um único gênero era utilizado apenas um controle negativo, do gênero correspondente.

O teste serológico utilizado foi o de "Enzyme linked immunosorbent assay", do tipo "Plate trapped antigen" ("PTA-ELISA"), modificado de Mowat \& Dawson (1987), conforme descrito no Protocolo 1.

De acordo com Sutula et al. (1986) o valor de corte para uma amostra ser considerada positiva ou negativa não é absoluto. Em função de testes preliminares, no presente estudo uma amostra foi considerada infectada apenas quando o valor médio das leituras de absorbância a $405 \mathrm{~nm}$ excedia em 3 vezes o valor médio das leituras das amostras sadias (controles). Caso o valor médio da amostra fosse considerado duvidoso, ou estivesse próximo do valor de separação, novo teste serológico, ou ainda testes complementares como o biológico e o de microscopia eletrònica, eram realizados. 
Protocolo 1. Teste de PTA-ELISA

- Colocação de extratos de plantas diluídos 1:10 em tampão carbonato (0,015 M $\mathrm{Na}_{2} \mathrm{CO}_{3}, 0,035 \mathrm{M} \mathrm{NaHCO}_{3}, \mathrm{pH} 9,6$ ) em microplacas de poliestireno (marca Corning) em volume de $100 \mu \mathrm{l}$ por "pocinho". Cada amostra foi colocada em 2 pocinhos da microplaca de ELISA, correspondendo a 2 repetições.

- Incubação das placas a $37^{\circ} \mathrm{C}$ por $1 \mathrm{~h}$ ou durante a noite a $4^{\circ} \mathrm{C}$ e lavagem das mesmas com tampão PBS-T $\left(0,0015 \mathrm{M} \mathrm{KH}_{2} \mathrm{PO}_{4}, 0,14 \mathrm{M} \mathrm{NaCl}, 0,004 \mathrm{M} \mathrm{Na}_{2} \mathrm{HPO}_{4}, 0,003\right.$ $\mathrm{M} \mathrm{KCl}, \mathrm{pH}$ 7,4 + 0,5 ml Tween-20/1) com três trocas de solução.

- Adição de $100 \mu \mathrm{l}$ do antissoro diluído 1:1000 em tampão Tris-HCl (0,2 M Tris$\mathrm{HCl}-0,15 \mathrm{M} \mathrm{NaCl}, \mathrm{pH} 7,2$ ) e nova incubação da microplaca a $37^{\circ} \mathrm{C}$ por $1 \mathrm{~h}$.

- Nova lavagem, procedida conforme descrição anterior.

- Adição de $100 \mu \mathrm{l}$ de "goat-anti-rabbit IgG" conjugado com fosfatase alcalina (SIGMA A-8025), diluído 1:8000 no tampão Tris- $\mathrm{HCl}$ e nova incubação da microplaca.

- Nova lavagem e adição de $100 \mu \mathrm{l}$ do substrato $\rho$-fosfato de nitrofenil (SIGMA N-9389) diluído em tampão dietanolamina 10\%, $\mathrm{pH} 9,8$, na proporção de $1 \mathrm{mg} / \mathrm{ml}$.

- Incubação da microplaca no escuro, a temperatura ambiente, por cerca de 40 a 90 minutos, para permitir a reação enzimática e leitura da absorbância de cada um dos pocinhos no leitor de ELISA, da marca Metertech $\sum 960$, utilizando-se fïltro de $405 \mathrm{~nm}$. 


\subsubsection{Indexação biológica}

A indexação biológica das plantas de orquídea foi realizada através da inoculação mecânica de extratos de amostras suspeitas de estarem infectadas por vírus em plantasteste indicadoras. Os extratos foram obtidos macerando-se as folhas em tampão fosfato $0,02 \mathrm{M}, \mathrm{pH} \mathrm{7,4}$. As folhas das plantas indicadoras foram previamente polvilhadas com carbureto de silício (carborundum) e inoculadas. Em seguida essas folhas foram lavadas para se retirar o excesso de abrasivo e de inóculo existentes. As plantas foram mantidas em casa de vegetação para avaliação com base na manifestação de sintomas.

\subsubsection{Microscopia eletrônica}

Quando necessário também foram feitos estudos de microscopia eletrônica para complementação do diagnóstico. Neste caso utilizaram-se as técnicas de imersão foliar rápida ("leaf dip") e/ou observações de cortes ultrafinos de tecidos de plantas doentes.

A técnica de imersão foliar rápida ou contrastação negativa foi realizada preparando-se um extrato da planta a ser testada em tampão fosfato $0,05 \mathrm{M}, \mathrm{pH} 7,2$. As telas de cobre, com película de Formvar/carbono foram então colocadas sobre esse macerado por 2 a 3 minutos. Em seguida foram lavadas com o mesmo tampão e água destilada. Finalmente foram contrastadas com acetato de uranila $1 \%$ por 1 a 2 minutos. $O$ excesso do corante foi eliminado e, após completamente seco, o material foi observado ao microscópio eletrônico de transmissào Zeiss EM 900, do Núcleo de Microscopia Eletrônica, ESALQ/USP.

Para se proceder os cortes ultrafinos, seguiu-se o Protocolo 2, descrito a seguir: 
Protocolo 2. Emblocagem e corte de material vegetal a ser analisado no microscópio eletrônico de transmissão

- Fixação de pequenos fragmentos de tecido foliar exibindo sintomas em glutaraldeído $2 \%$ e paraformaldeído $2 \%$ em tampão cacodilato $\left(0,05 \mathrm{M}, \mathrm{pH} 7,2, \mathrm{CaCl}_{2}\right.$ $0,001 \mathrm{M})$ por 2 horas a $4^{\circ} \mathrm{C}$.

- Lavagem com três trocas do mesmo tampão a intervalos de 10 minutos.

- Pós-fixxação em $\mathrm{OsO}_{4} 1 \%$, em tampão cacodilato, durante 2 h., a $25^{\circ} \mathrm{C}$.

- Lavagem do material com água destilada.

- Contrastação/fixação "en bloc" com acetato de uranila $1 \%$, durante a noite a $4^{\circ} \mathrm{C}$ e lavagem com água destilada.

- Desidratação em acetona 30\%, 50\%, 70\%, 90\% e 100\%, com cerca de 10 min. cada banho. Para o caso de acetona $100 \%$, foram feitos três banhos de 10 min. cada.

- Infiltração do material em meio de Spurr, numa mistura acetona/Spurr 1:1 por $4 \mathrm{~h}$. Posteriormente o Spurr foi infiltrado puro e mantido no material durante a noite.

- Transferência do material para molde com Spurr novo em estufa a $70^{\circ} \mathrm{C}$ por $48 \mathrm{~h}$

- Obtenção de cortes ultrafinos através de ultramicrótomo Reichert com navalha de diamante Diatome.

- Contrastação das secções em acetato de uranila 3\% por $15 \mathrm{~min}$. e citrato de chumbo por 10 min. e lavagem do material com água destilada

- Exames em microscópio eletrônico de transmissão Zeiss 900 M. 


\subsection{Avaliação da incidência de viroses em orquídeas}

\subsubsection{Locais das avaliações}

A avaliação da incidência de viroses em orquideas foi feita em cultivos comerciais e de coleção do Estado de São Paulo. Amostras foram coletadas de orquidários particulares nos seguintes municipios: Americana, Atibaia, Botucatu, Campinas, Carapicuiba, Guararema, Jundiai, Peruibe, Pindamonhangaba, Piracicaba, Santa Isabel, São Bernardo do Campo, São José dos Campos, São Paulo, Valinhos e Várzea Paulista. Foi analisado também o orquidário da ESALQ/USP, em Piracicaba, por apresentar grande interesse a nivel de coleção de gêneros, espécies e híbridos.

\subsubsection{Plantas amostradas}

A relação de todas as variedades, espécies e/ou híbridos amostrados e os respectivos locais de origem se encontra nos Apêndices 1 e 2.

As plantas analisadas foram escolhidas ao acaso. Procurou-se porém avaliar gêneros de interesse econômico que apresentassem grande volume de comercialização (para o caso de orquidários comerciais) ou interesse genético ou botânico, no orquidário da ESALQ. 


\subsubsection{Número e coleta de amostras}

O número de amostras analisado variou em função da importância dos gêneros e das espécies das plantas, procurando sempre que possivel coletar mais de um exemplar da mesma variedade e/ou espécie de interesse.

As coletas foram feitas ao acaso, retirando-se pedaços de folhas das plantas. Estes foram acondicionados individualmente em sacos plásticos devidamente etiquetados e trazidos para o laboratório para posteriores testes de detecção e identificação do(s) vírus presente(s), de acordo com as técnicas descritas anteriormente.

\subsubsection{Efeito da idade das plantas na incidência de viroses}

Apenas para os gêneros Cymbidium e Phalaenopsis, provenientes de um orquidário comercial do município de Atibaia, foi feita uma coleta separada de plantas de diferentes idades, a fïm de se avaliar a incidência de vírus em função do tempo que as plantas permaneciam no local de produção. De maneira análoga ao descrito anteriormente, as folhas foram acondicionadas em sacos plásticos, etiquetadas e levadas ao laboratório para serem submetidas aos testes de identificação dos vírus. Também nesse caso, o material vegetal era coletado independentemente da manifestação de sintomas. 


\subsection{Obtenção de matrizes livres de vírus}

\subsubsection{Escolha da planta}

O material vegetal utilizado nesse trabalho constou de plantas de Cymbidium Ayako Tanaka 'Hinodezuru'. Trata-se de uma variedade de grande interesse econômico, bastante apreciada no mercado e que se apresentava $100 \%$ infectada pelo ORSV. A confirmação da infecção com o ORSV foi feita através de testes de PTA-ELISA e biológico.

\subsubsection{Local de trabalho}

O trabalho de obtenção de matrizes de Cymbidium livres do ORSV através de cultivo de meristemas associado a quimioterapia foi desenvolvido no laboratório de cultura de tecidos de propriedade do Sr. Nobuyuki Hiranaka, localizado no município de Atibaia, SP. 


\subsubsection{Preparo dos meios de cultivo}

\subsubsection{Para meristemas}

A composição do meio de cultivo para meristemas (M) foi a normalmente utilizada pelo produtor há vários anos. Uma vez que esse meio é bastante adequado ao desenvolvimento das plantas, não foram feitas modificações qualitativas ou quantitativas, exceto a adição do virazole em diferentes concentrações. O meio básico para o cultivo de meristemas se encontra na Tabela 1.

Cerca de $10 \mathrm{ml}$ do meio para cultivo de meristemas eram vertidos para tubos de vidro com dimensões de $2,5 \times 15,0 \mathrm{~cm}$, onde eram autoclavados a $121^{\circ} \mathrm{C}$ por 1 hora.

\subsubsection{Para PLB e plântulas}

O meio para o desenvolvimento de PLB ("protocorm-like bodies" ou próembrióides) e plântulas de Cymbidium, denominado meio de transferência ou meio de subcultivo (S), tem composição parecida com a daquele utilizado para o desenvolvimento de meristemas e está descrito na Tabela 2.

Após o preparo do meio para PLB e plântulas, $30 \mathrm{ml}$ deste eram colocados em frascos de vidro com dimensões de $8,0 \times 12,0 \mathrm{~cm}$ e eram autoclavados a $121^{\circ} \mathrm{C}$ por $1 \mathrm{~h}$. 
Tabela 1. Composição do meio de cultivo utilizado para o desenvolvimento de meristemas de Cymbidium Ayako Tanaka 'Hinodezuru'

\begin{tabular}{lrcc}
\hline \multirow{2}{*}{ Ingredientes } & \multicolumn{3}{c}{ Concentração } \\
\cline { 2 - 4 } & 20,00 & $\mathrm{~g} / 1$ & $\mathrm{ml} / \mathrm{l}$ \\
\hline Açúcar & 2,00 & - & - \\
Hyponex $^{1}$ & 7,00 & - & - \\
Ágar & 1,33 & - & - \\
Peptona & 1,00 & - & - \\
Carvão ativado & - & - & - \\
FeNaEDTA & - & 30,00 & - \\
Piridoxina & - & 2,40 & - \\
Thiamina & - & 0,06 & 75,00 \\
Água de côco & & - & \\
\hline
\end{tabular}

$\mathrm{pH} 5,6$

${ }^{1}$ Hyponex $=$ produto registrado pela Hyponex Company Incorporated; Hyponex Corporation, Atlanta 30339, Georgia, U.S.A. Composição do produto: N-P-K =6,5-6-19 
Tabela 2. Composição do meio de cultivo para PLBs e plântulas de Cymbidium Ayako Tanaka 'Hinodezuru'

\begin{tabular}{lrrr}
\hline \multirow{2}{*}{ Ingredientes } & \multicolumn{2}{c}{ Concentração } \\
\cline { 2 - 3 } & 20,00 & $\mathrm{mg} / \mathrm{l}$ \\
\hline Açúcar & 2,60 & - \\
Hyponex & 9,40 & - \\
Ágar & 1,00 & - \\
Peptona & 1,00 & - \\
Carvão ativado & 50,00 & - \\
Caldo de batata & - & 30,00 \\
FeNaEDTA & - & 2,40 \\
Piridoxina & - & 0,06 \\
Thiamina & - & 100,00 \\
Ácido ascórbico & & \\
\hline
\end{tabular}
$\mathrm{pH} \mathrm{5,2}$ 


\subsubsection{Adição de virazole aos meios de cultivo}

A metodologia utilizada para a obtenção de material propagativo livre de vírus foi baseada em trabalho de Albouye et al. (1988), onde os autores introduziram o virazole somente nos meios de subcultivos (S) através de filtragem, nas concentrações de 25 e 35 ppm.

No presente trabalho o virazole foi introduzido nos meios de cultura $M$ e $S$, de duas maneiras diferentes: a) filtrado após a esterilização dos meios de cultivo e b) juntamente com os demais componentes dos meios, para posterior autoclavagem. Também foram estudadas diferentes concentrações de virazole em cada meio de cultivo (Tabela 3).

\subsubsection{Desinfestação superficial dos pseudobulbos}

Uma etapa de grande importância para o cultivo "in vitro" é a desinfestação superficial do material vegetal. Mais uma vez, o procedimento adotado foi o normalmente utilizado pelo laboratório do produtor, conforme descrito no Protocolo 3. 
Tabela 3. Relação dos tratamentos de acordo com o tipo de meio de cultura, concentração do virazole e forma como este foi adicionado ao meio

\begin{tabular}{|c|c|c|c|}
\hline $\begin{array}{c}\text { Designação dos } \\
\text { tratamentos }^{1}\end{array}$ & Meio de cultivo & $\begin{array}{c}\text { Forma de introdução } \\
\text { do virazole }\end{array}$ & $\begin{array}{l}\text { Concentração do } \\
\text { virazole (ppm) }\end{array}$ \\
\hline Controle & - & - & 0 \\
\hline M-A-15 & M & $\mathrm{A}$ & 15 \\
\hline$M-F-15$ & M & $\mathrm{F}$ & 15 \\
\hline M-A-20 & M & A & 20 \\
\hline$M-F-20$ & M & $\mathrm{F}$ & 20 \\
\hline$M-A-25$ & M & A & 25 \\
\hline$M-F-25$ & M & $\mathrm{F}$ & 25 \\
\hline S-A-20 & S & A & 20 \\
\hline S-F-20 & S & $\mathrm{F}$ & 20 \\
\hline S-A-25 & S & A & 25 \\
\hline S-F-25 & S & $\mathrm{F}$ & 25 \\
\hline S-A-30 & S & A & 30 \\
\hline$S-F-30$ & S & $\mathrm{F}$ & 30 \\
\hline
\end{tabular}

Tratamento controle, onde os meristemas foram cultivados em meio de cultura sem adição de virazole em qualquer fase do seu desenvolvimento (-), Virazole adicionado apenas ao meio para meristema $(\mathrm{M})$, virazole adicionado apenas aos meios de subcultivo (S), virazole autoclavado juntamente com o meio de cultivo (A), virazole introduzido através de filtragem no meio de cultivo previamente autoclavado $(\mathrm{F})$ 
Protocolo 3. Desinfestação superficial dos pseudobulbos de Cymbidium

- Limpeza e lavagem dos pseudobulbos em água corrente.

- Imersão do material vegetal em uma solução de $0,5 \mathrm{ml} / 1$ de carbendazin e 0,2 $\mathrm{ml} / \mathrm{l}$ de cloranfenicol por 24 horas.

- Nova lavagem dos pseudobulbos em água corrente por $15 \mathrm{~min}$.

- Colocação do material em frasco vazio autoclavado com solução de $0,2 \mathrm{ml} / \mathrm{l}$ de cloranfenicol por $15 \mathrm{~min}$.

- Lavagem dos pseudobulbos em água esterilizada (1 vez).

- Imersão dos pseudobulbos em hipoclorito de cálcio $2 \%$ durante 10 min. A partir dessa etapa, todas as demais foram realizadas no interior da câmara de fluxo laminar.

- Lavagem em água esterilizada (1 vez) e imersão dos pesudobulbos em hipoclorito de cálcio $1 \%$, por $10 \mathrm{~min}$.

- Nova lavagem com água esterilizada (3 vezes) e retirada dos meristemas. 


\subsubsection{Retirada dos meristemas}

Foram cortados 19 pseudobulbos de Cymbidium Ayako Tanaka 'Hinodezuru' infectados com o ORSV, com uma média de 4 meristemas retirados de cada um, num total de 79 meristemas, apicais ou laterais, conforme procedimento corriqueiro em produção comercial. A região meristemática foi retirada, em condição asséptica, sob microscópio estereoscópico, com o auxílio de uma lâmina fixada numa haste. Os tamanhos foram variáveis, sendo a maioria em torno de 1,0 mm (Figura 1).

\subsubsection{Inoculação e cultivo dos meristemas}

Cada meristema foi colocado isoladamente em um tubo contendo meio de cultivo descrito anteriormente e incubado no escuro durante os primeiros sete dias após a sua retirada do pseudobulbo, até o inicio do aparecimento de coloração esverdeada. Após essa fase, os meristemas foram mantidos em sala climatizada com fotoperiodo de 16 horas de luz e temperatura de $25^{\circ} \mathrm{C}\left( \pm 3^{\circ} \mathrm{C}\right)$. Após cerca de 40 a 50 dias, os meristemas (nessa fase chamados PLBs) foram repicados, sendo que depois dessa primeira transferência, a cada $21( \pm 3)$ dias, nova repicagem era realizada. A Figura 2 ilustra as fases de desenvolvimento de meristema, passando por PLB até a formação de plântulas.

Meristemas inoculados em meio $M$ contendo virazole foram sempre repicados para meios S sem virazole. Os meristemas inoculados em meio $\mathrm{M}$ sem virazole foram sempre transferidos para meios $\mathrm{S}$ com o agente antiviral. 


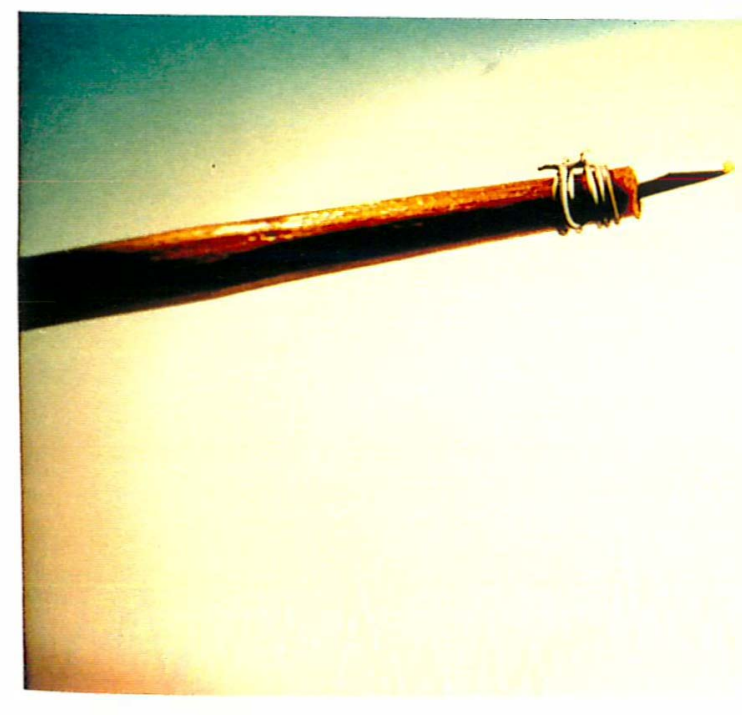

Figura 1. Região meristemática com cerca de $1 \mathrm{~mm}$ recém retirada de pseudobulbo de C.ymbidium

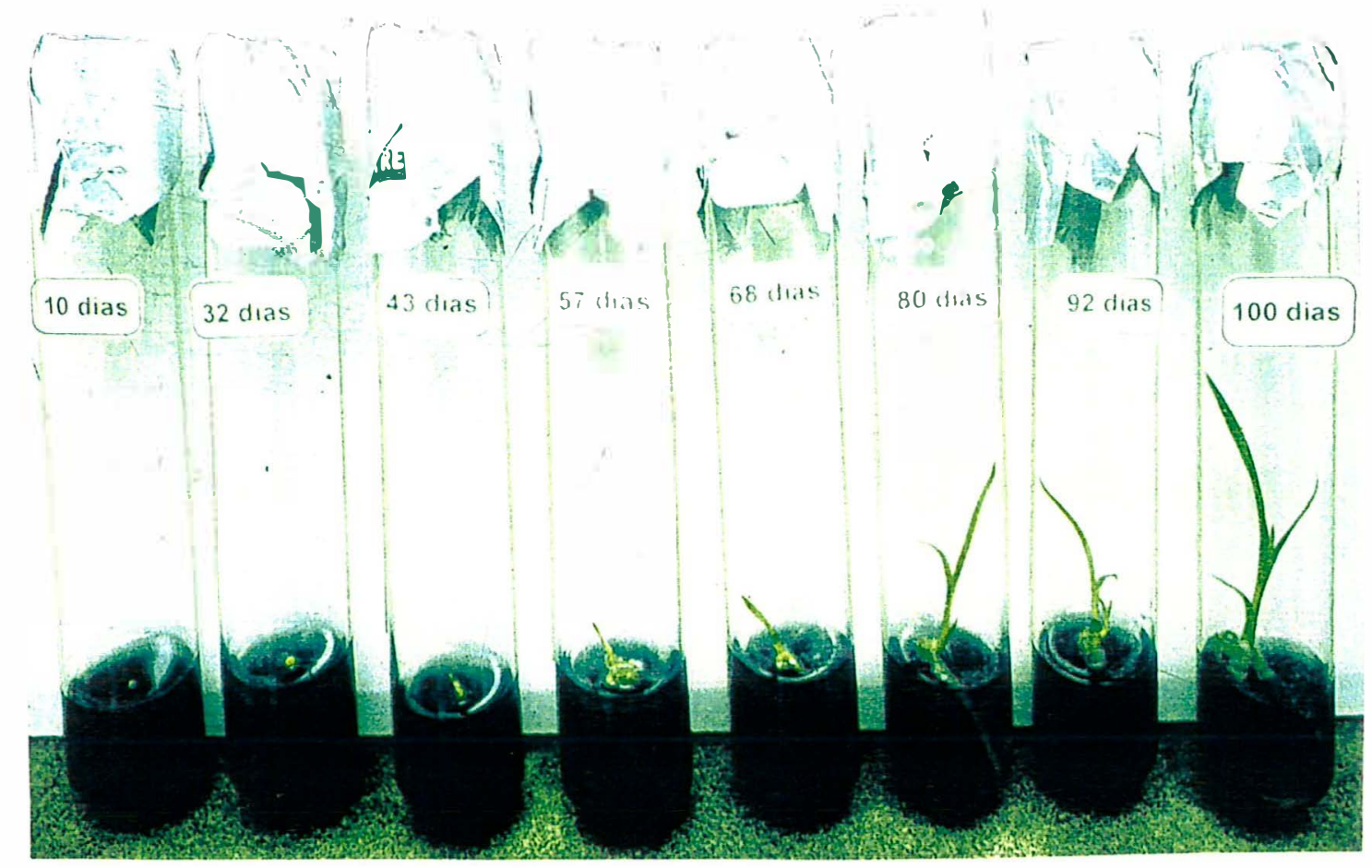

Figura 2. Fases do desenvolvimento de explante de Cymbidium: meristema, PLB e plântula 


\subsubsection{Transplante e aclimatação das plântulas}

O transplante das plântulas (denominadas plantas "ex vitro") foi feito para bandejas de plástico contendo pó de xaxim autoclavado como substrato. Antes porém, as plântulas foram lavadas em água corrente, para a retirada de possiveis restos de meio de cultura das raizes e passadas por solução de benomyl $0,5 \mathrm{ml} / \mathrm{l}$, a fím de se evitar podridões provocadas por fungos.

Após o transplante foram mantidas em condição de alta umidade relativa do ar, proporcionada por uma camada de plástico umedecido envolvendo as bandejas, para sofrerem aclimatação. Todo o material foi levado para uma casa de vegetação, sendo que o plástico foi retirado após uma semana.

As regas foram frequentes e as adubações liquidas foram as recomendadas para orquídeas do gênero Cymbidium.

\subsubsection{Indexação das plantas "ex vitro"}

A presença do ORSV foi avaliada após 1 ano do início do trabalho, correspondendo a cerca de 1 mês após a aclimatação. Assim, plantas "ex vitro" foram indexadas através do teste serológico de ELISA, teste biológico e de microscopia eletrônica. 


\section{RESULTADOS}

\subsection{Identificação dos vírus}

\subsubsection{Com base nos sintomas}

Os sintomas, por serem o primeiro indício de que uma planta pode estar doente, apresentam importante papel na diagnose. No decorrer dos estudos feitos nesse trabalho, procurou-se associar a presença e o tipo de sintoma apresentado por um grande número de plantas examinadas com a infecção viral, especialmente com o ORSV e o CyMV. Foi observado principalmente o aparecimento de manchas necróticas no limbo foliar, amarelamento ou arroxeamento das folhas, mosaico, entre outros. A Tabela 4 mostra a associação entre a presença do ORSV, do CyMV e do complexo viral ORSV + CyMV e a manifestação de sintomas em alguns gêneros de orquídea provenientes de orquidários particulares e/ou da ESALQ/USP.

Apesar da porcentagem de plantas sadias com sintomas parecidos com aqueles causados por vírus ser relativamente elevada, para a maioria dos gêneros de orquídeas analisadas, foi possivel verificar que alguns sintomas se mostraram relativamente consistentes, podendo auxiliar no diagnóstico de viroses desta ornamental, desde que 
utilizados com cautela. A seguir é apresentada uma descrição dos sintomas mais frequentes associados principalmente com a infecção com o ORSV e com o CyMV ou pelo complexo viral ORSV + CyMV em plantas dos gêneros Catıleya, Cymbidium. Dendrobium, Laelia, Oncidium e Phalaenopsis.

Tabela 4. Associação entre a presença ou ausência de sintomas e a infecção com o ORSV, o CyMV ou o complexo viral ORSV + CyMV em diferentes gêneros de orquídeas

\begin{tabular}{|c|c|c|c|c|}
\hline \multirow[t]{2}{*}{ Gênero } & \multicolumn{3}{|c|}{$\begin{array}{c}\mathrm{N}^{\circ} \text { de plantas assintomáticas } / \mathrm{N}^{\circ} \text { de plantas } \\
\text { infectadas testadas }\end{array}$} & \multirow{2}{*}{$\begin{array}{c}\mathrm{N}^{\circ} \text { de plantas sadias } \\
\mathrm{N}^{\mathrm{o}} \text { de plantas com } \\
\text { sintomas testadas }\end{array}$} \\
\hline & ORSV & CyMV & ORSV+CyMV & \\
\hline Cattleya & $2 / 9(22,2)^{\top}$ & $0 / 16(0,0)$ & $0 / 7(0,0)$ & $26 / 58(44,8)$ \\
\hline Cymbidium & $4 / 69(5,8)$ & - & $0 / 2(0,0)$ & $31 / 98(31,6)$ \\
\hline 1)endrobium & - & $7 / 12(58,3)$ & - & $7 / 12(58,3)$ \\
\hline Laelia & $3 / 4(75,0)$ & $4 / 5(20,0)$ & - & $46 / 51(90,2)$ \\
\hline Oncidium & $0 / 1(0,0)$ & $2 / 13(14,4)$ & - & $18 / 30(60,0)$ \\
\hline Phalaenopsis & $3 / 5(60,0)$ & $7 / 25(28,0)$ & $11 / 35(31,4)$ & $26 / 70(37,1)$ \\
\hline Outros (50 gên.) & $1 / 6(16,7)$ & $3 / 20(15,0)$ & $2 / 6(33,3)$ & $69 / 94(73,4)$ \\
\hline Híbr. intergenér. & $3 / 6(50,0)$ & $1 / 3(33,3)$ & - & $14 / 19(73,7)$ \\
\hline Total & $16 / 100(16,0)$ & $24 / 94(25,5)$ & $13 / 50(26,0)$ & $237 / 432(54,9)$ \\
\hline
\end{tabular}

-T valor entre parêntesis representa a porcentagem em relação ao total

(-) Ausência de infecção nas plantas testadas 


\section{Cattleya}

Os sintomas provocados por ORSV e por CyMV em Cattleya mostraram-se semelhantes na maioria das plantas analisadas, sendo caracterizados principalmente pela necrose do limbo foliar. As lesões necróticas, puntiformes ou irregulares, geralmente ocorriam nas duas faces do limbo, sendo mais evidentes na região central da página inferior da folha, chegando, em alguns casos, a ocupar grande parte da mesma (Figura 3). Esporadicamente as lesões eram na forma de riscas e apareciam acompanhando as bordas do limbo foliar. Com certa frequência, em função da espécie ou hibrido de Cattleya, os sintomas apareciam como amarelecimento, seja na forma de manchas difusas, principalmente na face inferior da folha, em faixas, ou ainda generalizado, com início no ápice do limbo, evoluindo para a base da folha. Alguns hibridos de (attleya apresentaram "color-break" (descontinuidade da coloração da flor) quando infectados com o ORSV, e necrose floral quando com o CyMV (Figura 3). Outras plantas se mostraram assintomáticas quando infectadas com o ORSV.

\section{Cymbidium}

Tanto o CyMV quanto o ORSV provocaram sintomas de mosaico em plantas de Cymbidium indexadas no presente trabalho. A maior diferença entre eles parece ser a de que o CyMV promoveu, em todas as plantas infectadas, o aparecimento de necrose no limbo foliar, enquanto o ORSV causou maior diversidade de sintomas. Em função da variedade de Cymbidium infectada com esse vírus, as plantas mostravam-se assintomáticas ou com sintomas de mosaico comum ou amarelo em faixas (Figura 4). 


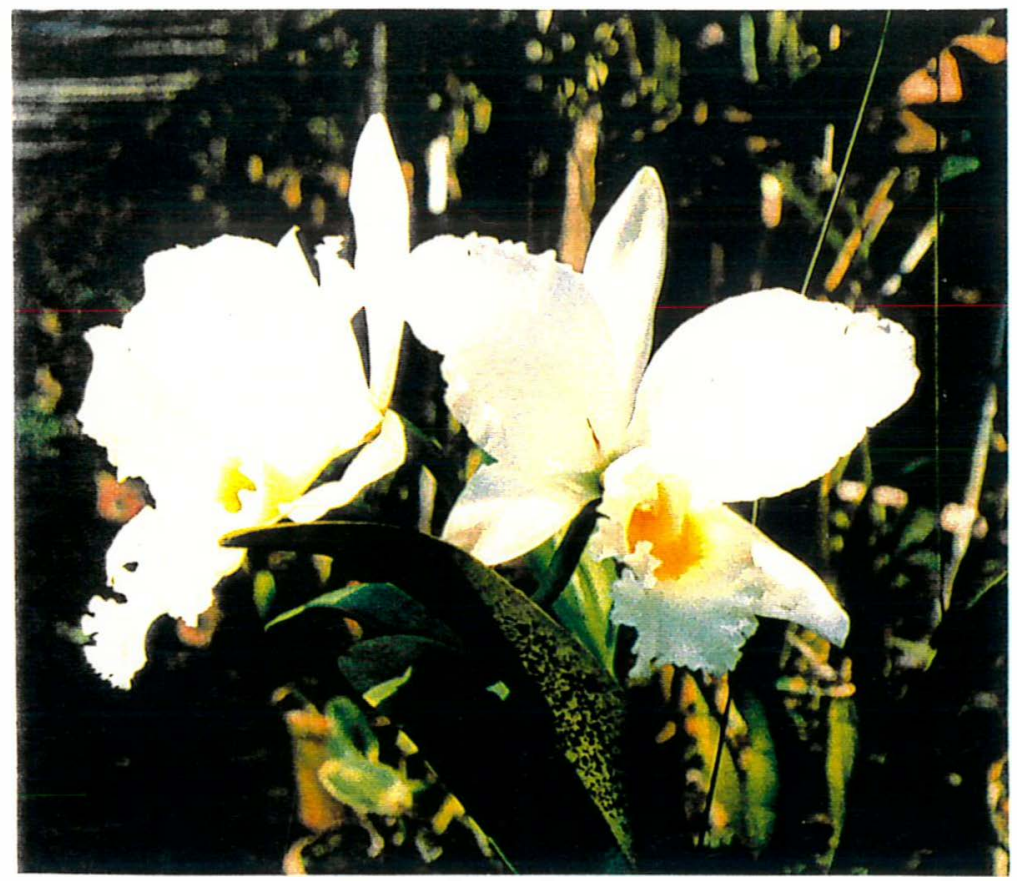

Figura 3. Necrose em folha e início de necrose floral em Catlleya infectada pelo CyMV

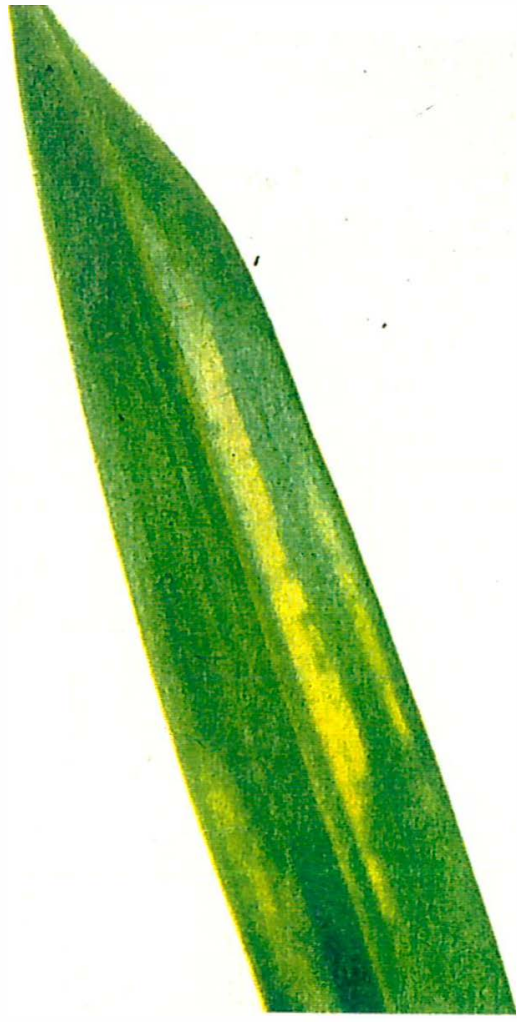

Figura 4. Mosaico amarelo em faixas provocado pelo ORSV em Cymbidium 
Em alguns casos, observou-se o aparecimento de pontos necróticos em folhas velhas. Com bastante frequência o sintoma provocado pelo ORSV se manifestava como amarelecimento generalizado do limbo, sendo facilmente confundido com deficiência de nitrogênio. Em nenhuma variedade de Cymbidium foram observados sintomas florais.

\section{Dendrobium}

Nenhuma planta de Dendrobium analisada mostrou-se infectada com o ORSV. Em relação ao CyMV, os sintomas causados em diferentes espécies e híbridos foram geralmente suaves, como pequenas pontuações ou riscas amareladas difusas na face superior do limbo foliar em D. chrysotoxum. Alguns híbridos de D. nobile apresentaram lesões necróticas nas folhas (Figura 5). Plantas de D. thyrsiflorum, D. Madame Chuli e D. Pixie Princess infectadas com o CyMV mostraram-se assintomáticas.

\section{Laelia}

A maioria das plantas de Laelia infectada com o CyMV apresentava sintomas de amarelecimento foliar, pequenos pontos escuros esparsos no limbo, lesões necróticas irregulares e escuras nas duas faces da folha, geralmente aparecendo na região basal do limbo (Figura 6) ou ainda mosaico amarelo em faixas, mais evidente no lado superior da folha. O sintoma mais característico provocado pelo ORSV era o aparecimento de grande número de lesões escuras principalmente na face superior do limbo. É importante lembrar que algumas espécies e/ou híbridos de Laelia apresentam coloração arroxeada, facilmente confundida com sintoma provocado por vírus. 


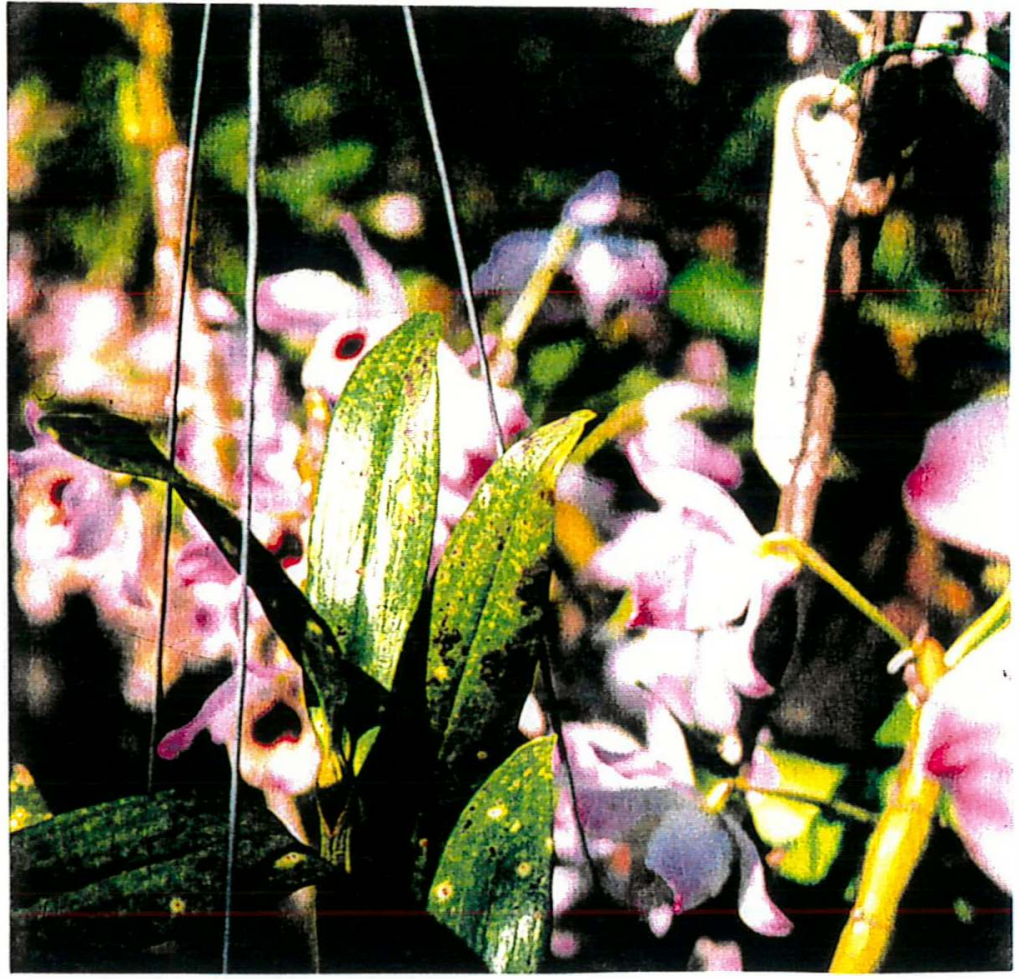

Figura 5. Lesões necróticas em folhas de Dendrobium associadas com o CyMV

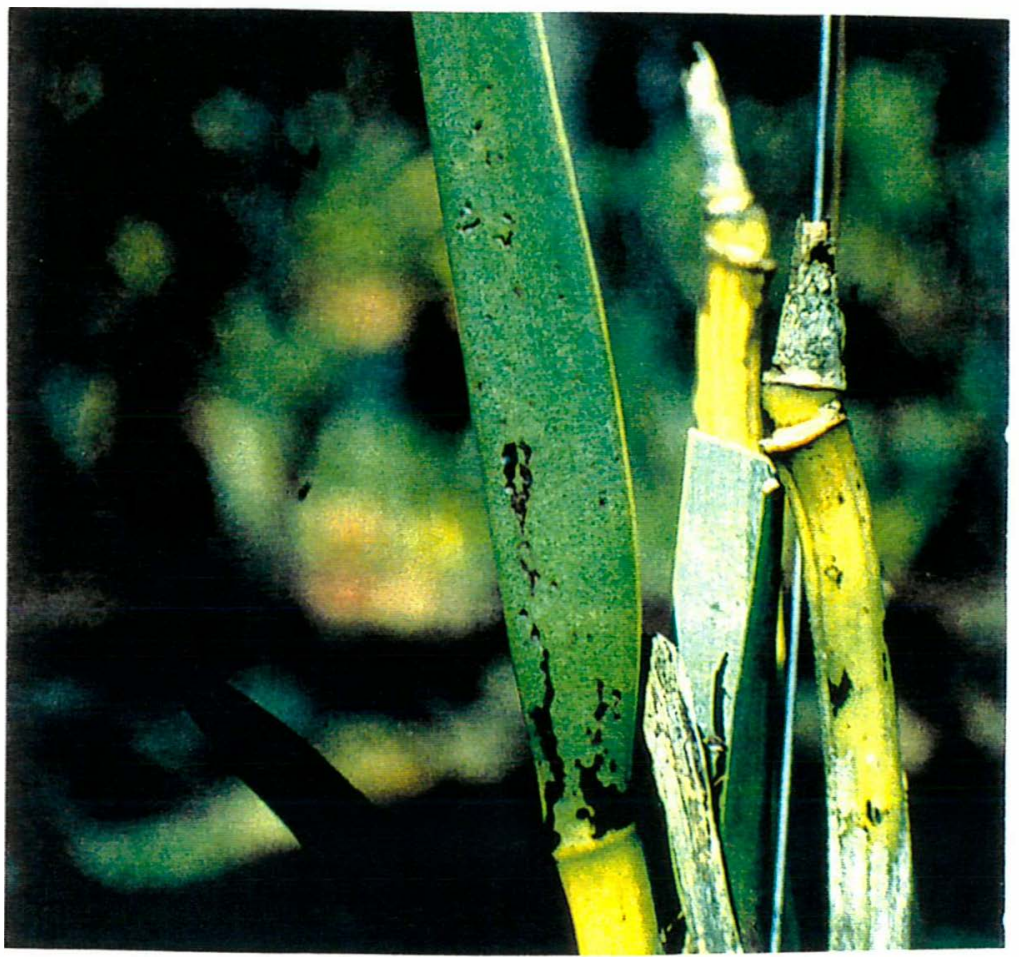

Figura 6. Manchas necróticas causadas por CyMV em folha de Laelia 


\section{Oncidium}

Foram encontradas diversas plantas de Oncidium infectadas com o CyMV. O principal sintoma observado foi o de mosaico amarelo em faixas, podendo evoluir para necrose nas duas faces do limbo foliar (Figura 7). Em alguns casos as plantas infectadas por esse vírus permaneciam assintomáticas.

\section{Phalaenopsis}

Os sintomas de vírus em Phalaenopsis mostraram ser característicos e constantes, mesmo em diferentes híbridos do gênero. Plantas infectadas com o CyMV apresentavam manchas amareladas e/ou avermelhadas difusas, na face superior da folha e necrose ou "torção" do limbo foliar, na sua face inferior. O ORSV provocava sintomas de amarelecimento e avermelhamento generalizado do limbo. Em alguns casos observou-se a presença de algumas áreas verdes, dando um aspecto de mosaico.

Os sintomas mais comumente observados em plantas com infecção mista (ORSV + CyMV) eram áreas amareladas em forma de anéis na face inferior do limbo, conferindo um aspecto de folha "tachada", com necrose na região central da mancha (Figura 8). Apesar de ocorrer com menor frequência, foram encontradas plantas assintomáticas infectadas com ambos os vírus. 


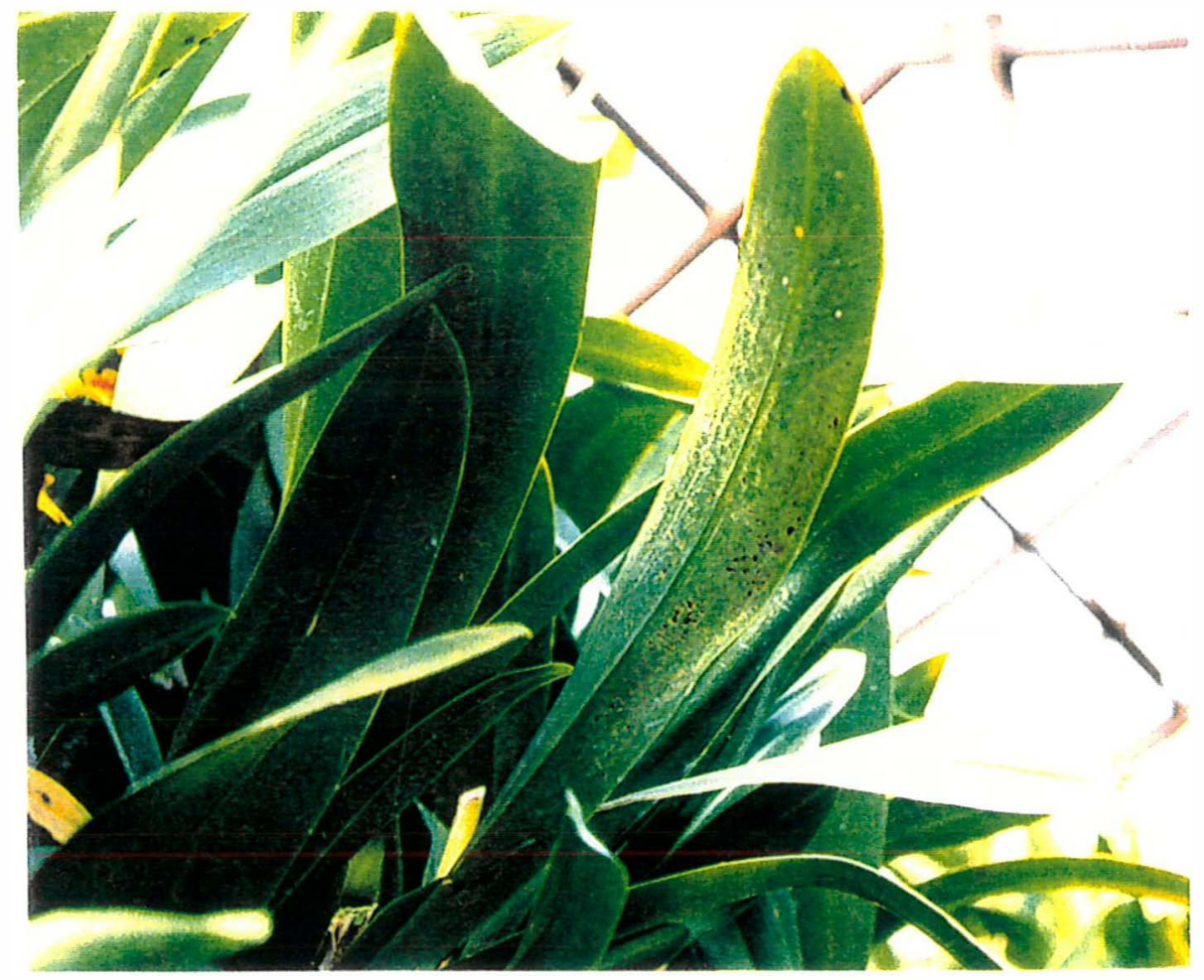

Figura 7. Mosaico acompanhado de necrose em Oncidium infectado com o CyMV

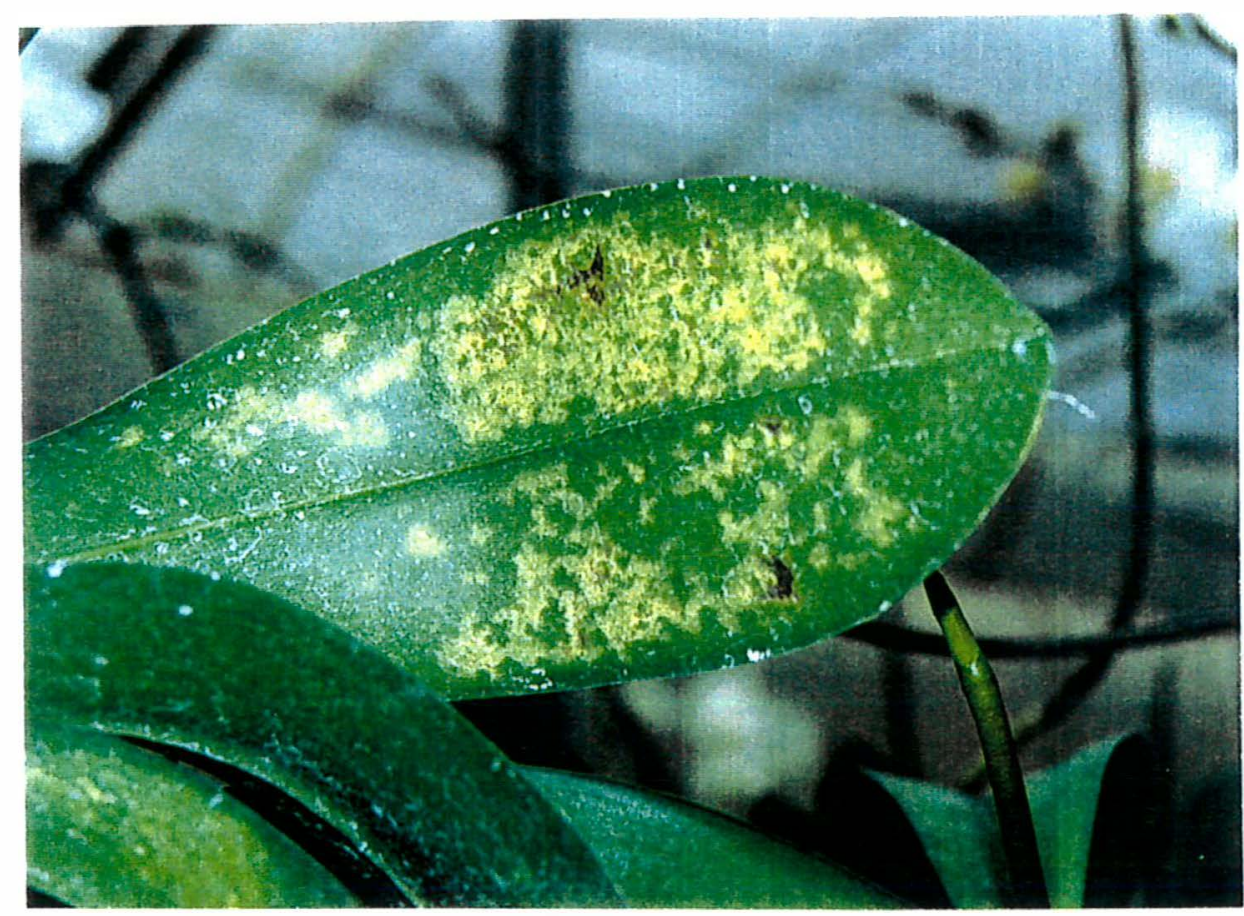

Figura 8. Folha "tachada" de Phalcienopsis infectado com ORSV + CyMV. 


\subsubsection{Por meio do teste de ELISA}

O teste serológico de PTA-ELISA mostrou-se altamente eficiente para a detecção e identificação do ORSV e do CyMV. Nenhuma amostra apresentou reação com antissoros contra o CMV, o CyRSV e o DsMV.

\subsubsection{Por meio de teste biológico}

As espécies indicadoras utilizadas no presente trabalho, Nicotiana tabacum 'TNN' e C. occidentalis, reagiram de maneira consistente e adequada quando inoculadas com o ORSV e o CyMV, respectivamente. As duas indicadoras apresentavam grande número de lesões locais necróticas aos 3 a 5 dias após a inoculação mecânica.

\subsubsection{Através de exames de microscopia eletrônica}

Exames de microscopia eletrônica possibilitaram a confirmação dos casos duvidosos e a visualização de partículas do tipo rhabdovirus associadas a sintomas de mancha anelar em folhas de diversos gêneros de orquídeas.

Através de cortes ultrafinos observou-se a presença de dois padrões distintos de partículas de rhabdovirus, um com morfologia bastante semelhante a do OFV e inclusões típicas de "roda de bicicleta", tendo sido denominado "Orchid fleck-type virus", e outro com padrões semelhantes aos do vírus da leprose dos citros (Colariccio et al., 1995), 
tendo sido denominado "Citrus leprosis-type virus". As Figuras 9 e 10 ilustram esses dois tipos de partículas e inclusões, sendo que o presente trabalho corresponde à primeira observação desta natureza em plantas de orquídeas com sintomas de mancha anelar.

A Tabela 5 apresenta os resultados de exames de microscopia eletrônica feitos em tecidos de plantas de diferentes gêneros de orquídeas.

Tabela 5. Resultados de exames de cortes ultrafinos para a detecção de partículas virais em tecidos de diferentes gêneros de orquídeas observados em microscópio eletrônico de transmissão

\begin{tabular}{|c|c|c|c|}
\hline \multirow[t]{2}{*}{ Gênero } & \multicolumn{3}{|c|}{$\mathrm{N}^{\circ}$ de plantas positivas/ $\mathrm{N}^{\prime}$ de plantas examinadas } \\
\hline & ORSV & OFV-type & CLV-type \\
\hline Brasisia & $0 / 1$ & $0 / 1$ & $0 / 1$ \\
\hline Cymbidium & $6 / 8$ & $1 / 8$ & $0 / 8$ \\
\hline Encyclia & $0 / 3$ & $0 / 3$ & $0 / 3$ \\
\hline Jumellea & $0 / 1$ & $0 / 1$ & $0 / 1$ \\
\hline Maxillaria & $0 / 1$ & $0 / 1$ & $0 / 1$ \\
\hline Miltonia & $0 / 4$ & $3 / 4$ & $0 / 4$ \\
\hline Oncidium & $0 / 1$ & $1 / 1$ & $0 / 1$ \\
\hline Oncidium x Rodriguezia & $0 / 1$ & $0 / 1$ & $0 / 1$ \\
\hline Phaius & $1 / 1$ & $0 / 1$ & $1 / 1$ \\
\hline Xylobium & $0 / 1$ & $0 / 1$ & $1 / 1$ \\
\hline
\end{tabular}




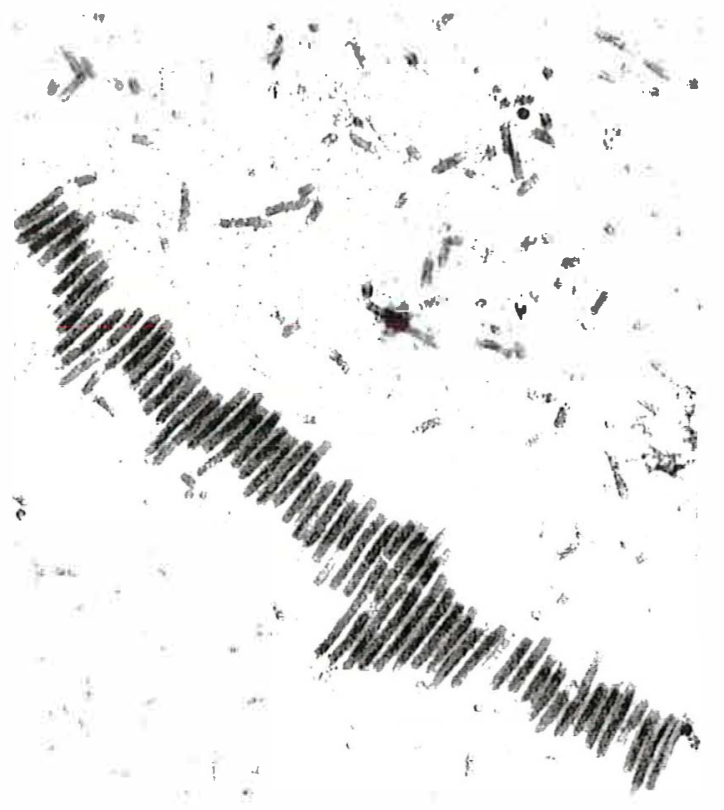

A

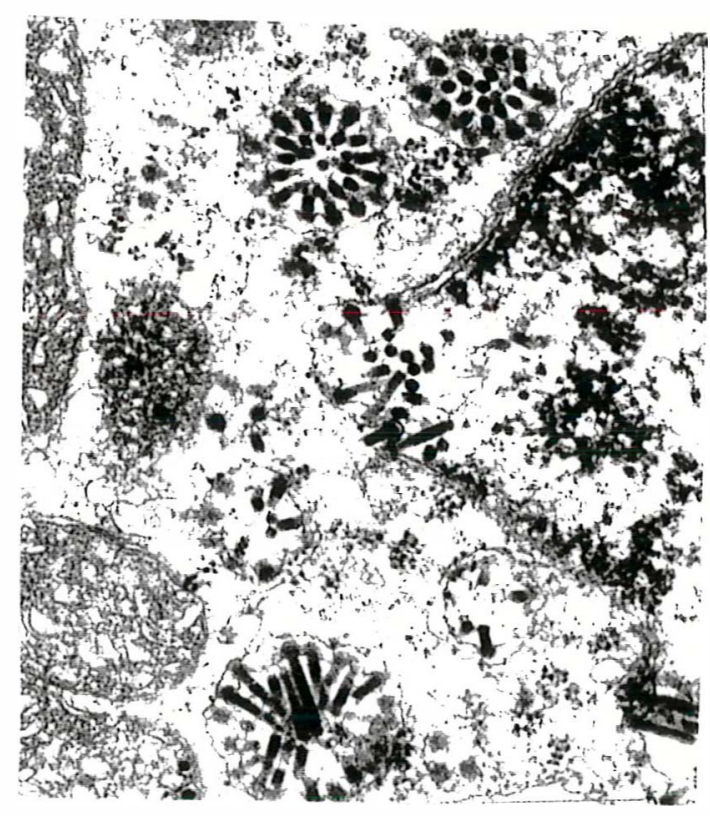

$\mathrm{B}$

Figura 9. Aspecto de corte ultrafino de tecido de Oncidium (A) e Cymbidium (B) com partículas e inclusões ("roda de bicicleta") típicas de "Orchid fleck-type virus". Aumento de $35.000 \mathrm{x}$.

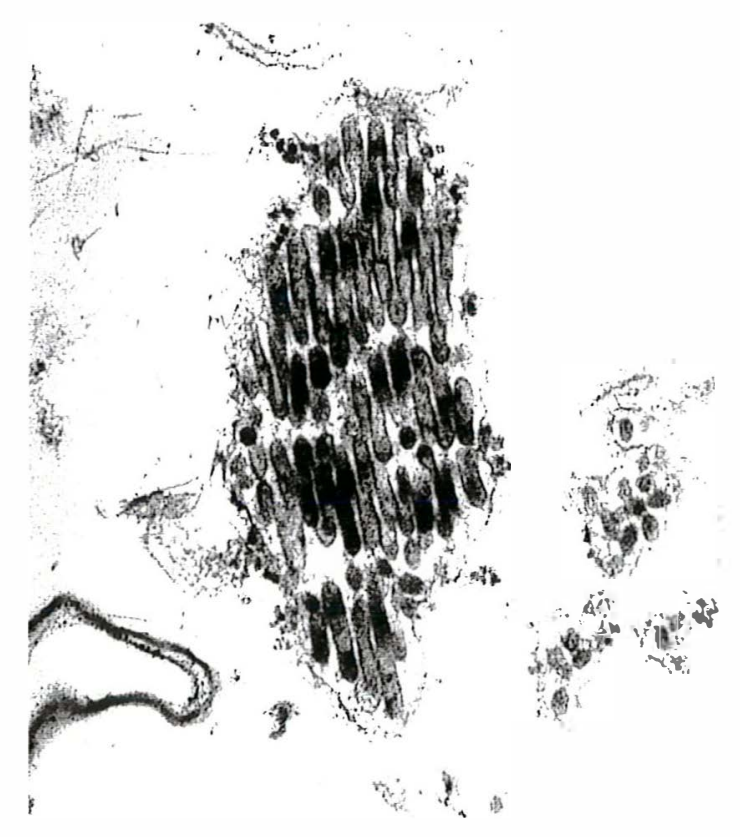

A

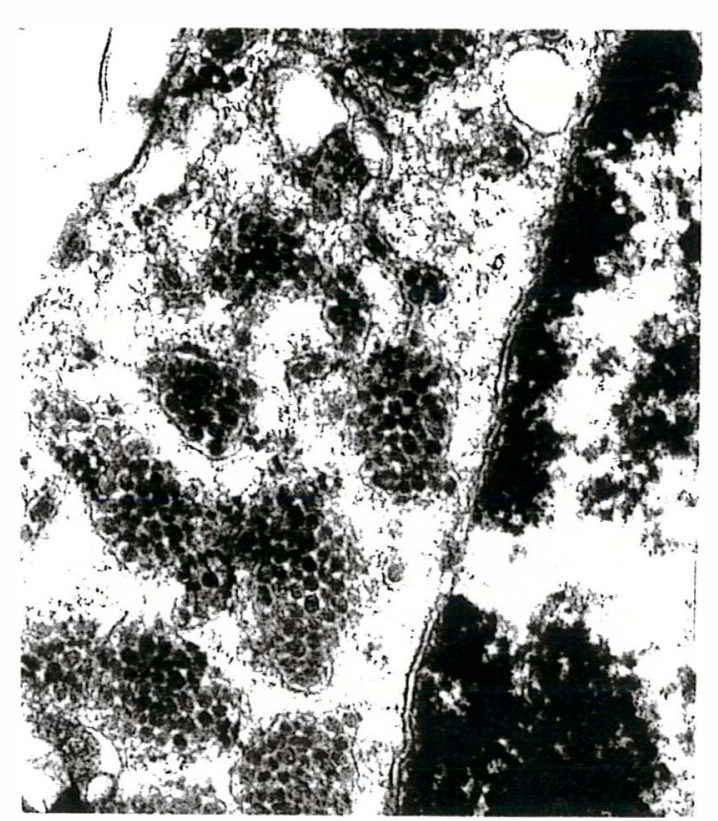

$\mathrm{B}$

Figura 10. Micrografia de Phaius (A) e Xylobium (B) com partículas de "Citrus leprosistype virus". Aumento de $45.000 \mathrm{x}$. 


\subsection{Incidência de viroses}

\subsubsection{Em orquidários particulares}

Para quantificar a incidência de viroses em orquídeas de cultivos particulares do Estado de São Paulo foram amostradas 1458 plantas, de 47 gêneros e 12 híbridos intergenéricos, provenientes de 16 municípios diferentes. Todas as plantas foram indexadas para a presença do CyMV, 1420 foram indexadas para o ORSV, 676 para o CyRSV, 651 amostras foram testadas para o CMV e 646 para o DsMV.

A indexação para quantificar a incidência desses vírus foi feita principalmente através do teste serológico de PTA-ELISA. A relação de todas as plantas testadas, bem como sua procedência, se encontra no Apêndice 1. A Tabela 6 apresenta de forma agrupada os gêneros e híbridos que se mostraram infectados com o ORSV, com o CyMV ou com os dois vírus simultaneamente.

Foram encontradas plantas com vírus em praticamente todos os locais amostrados. Em Santa Isabel, São José dos Campos e Valinhos, onde apenas uma planta de cada localidade havia sido testada, não foi encontrada infecção viral. Os resultados apresentados na Tabela 6 mostram que a incidência do ORSV isoladamente nesses cultivos foi de 7,6\%, enquanto a do CyMV foi de 7,4\% e a do complexo viral ORSV + CyMV foi de 3,6\%. Levando-se em consideração a presença de ORSV, isoladamente ou em conjunto com o CyMV e vice-versa, tem-se que o ORSV foi encontrado em 11,2\% das amostras testadas enquanto o CyMV em 10,9\%. 
Tabela 6. Incidência do ORSV, do CyMV e do complexo ORSV + CyMV em gêneros e híbridos de orquídeas de cultivos particulares de 16 municípios do Estado de São Paulo

\begin{tabular}{|c|c|c|c|c|c|c|}
\hline \multirow{2}{*}{ Gênero } & \multicolumn{6}{|c|}{$\mathrm{N}^{\circ}$ de plantas infectadas $/ \mathrm{N}^{\circ}$ de plantas testadas } \\
\hline & ORSV & $\%$ & CyMV & $\%$ & ORSV+CyMV & $\%$ \\
\hline Ansellia & $0 / 1$ & 0,0 & $1 / 1$ & 100,0 & $0 / 1$ & 0,0 \\
\hline Brassolaeliocattleya* & $0 / 4$ & 0,0 & $1 / 4$ & 25,0 & $1 / 4$ & 25,0 \\
\hline Cattleya & $8 / 91$ & 8,8 & $34 / 107$ & 31,8 & $11 / 91$ & 12,1 \\
\hline Coelogyne & $0 / 10$ & 0,0 & $1 / 10$ & 10,0 & $0 / 10$ & 0,0 \\
\hline Cymbidium & $88 / 897$ & 9,8 & $1 / 912$ & 0,1 & $2 / 897$ & 0,2 \\
\hline Dendrobium & $0 / 50$ & 0,0 & $13 / 54$ & 24,1 & $0 / 50$ & 0,0 \\
\hline Dendrochilum & $0 / 2$ & 0,0 & $1 / 2$ & 50,0 & $0 / 2$ & 0,0 \\
\hline Epidendrum & $1 / 5$ & 20,0 & $0 / 5$ & 0,0 & $0 / 5$ & 0,0 \\
\hline Laelia & $1 / 22$ & 4,5 & $2 / 22$ & 9,1 & $2 / 22$ & 9,1 \\
\hline Laeliocattleya* & $2 / 6$ & 33,3 & $2 / 6$ & 33,3 & $1 / 6$ & 16,7 \\
\hline Oncidium & $0 / 36$ & 0,0 & $12 / 36$ & 33,3 & $0 / 36$ & 0,0 \\
\hline Phalaenopsis & $6 / 179$ & 3,4 & $33 / 178$ & 18,5 & $34 / 177$ & 19,2 \\
\hline Psychopsis & $0 / 1$ & 0,0 & $1 / 1$ & 100,0 & $0 / 1$ & 0,0 \\
\hline Sophrolaeliocattleya* & $0 / 6$ & 0,0 & $1 / 6$ & 16,7 & $0 / 6$ & 0,0 \\
\hline Outros híbr. intergenér. & $1 / 23$ & 4,3 & $2 / 23$ & 8,7 & $0 / 23$ & 0,0 \\
\hline Não identificadas & $1 / 19$ & 5,3 & $3 / 20$ & 15,0 & $0 / 20$ & 0,0 \\
\hline
\end{tabular}

* Gêneros que não ocorrem naturalmente 
O CMV, o CyRSV e o DsMV não foram encontrados em nenhuma das plantas analisadas. As poucas amostras consideradas duvidosas para um desses virus foram retestadas através de ELISA, examinadas em microscópio eletrònico ou inoculadas mecanicamente nas plantas indicadoras apropriadas. Em nenhum caso houve a confirmação de infecção com um desses vírus.

Os outros gêneros testados e que não apresentaram plantas infectadas com um dos cinco virus indexados foram: Acacallis, Ascocendu*, Ascocentrum, Ascodoritis*, Bifrenaria, Brassavola, Brassia, Brassocattleya*, Bulbophyllum, Catasetum, Cochleantes, Encyclia. Eria, Galeandra, Gomesa, Gongora, Habernaria, Koellensteinia, Miltonia, Oeceoclades, Paphiopedilum, Pleurothallıs, Renanthera, Rhyncholaelia*, Rhynchostilis, Rodriguezia, Sigmatostalix, Sophronitis, Stanhopea, Vanda, Vanilla, Xylobium e Zygopetalum (Apêndice 1).

Os resultados das avaliações de incidência de vírus, principalmente do ORSV e do CyMV, em função da idade das plantas de Cymbidium e Phalaenopsis encontram-se apresentados nas Tabelas 7 e 8 , respectivamente. Nas plantas de (ymbidium amostradas predominou o ORSV. A incidência desse vírus era maior, quanto mais velho fosse o lote de plantas amostradas, com exceção das plantas matrizes, com mais de 4 anos, as quais se encontravam separadas da área de produção. Nas plantas de Phalaenopsis foram encontrados tanto o ORSV quanto o CyMV, cujas incidências eram proporcionalmente crescentes à idade das plantas avaliadas.

\footnotetext{
* Gêneros que não ocorrem naturalmente
} 
Tabela 7. Incidência do ORSV, do CyMV ou do complexo viral ORSV + CyMV em função da idade das plantas do gênero Cymbidium

\begin{tabular}{ccccccc}
\hline \multirow{2}{*}{$\begin{array}{c}\text { Idade } \\
\text { (anos })\end{array}$} & \multicolumn{5}{c}{$\mathrm{N}^{\mathrm{o}}$ de plantas infectadas $\mathrm{N}^{\mathrm{o}}$ de plantas testadas } \\
\cline { 2 - 7 } & ORSV & $\%$ & CyMV & $\%$ & ORSV + CyMV & $\%$ \\
\hline 1 & $0 / 14$ & 0,0 & $0 / 14$ & 0,0 & $0 / 14$ & 0,0 \\
$1-2$ & $2 / 54$ & 3,7 & $0 / 54$ & 0,0 & $0 / 54$ & 0,0 \\
$2-4$ & $76 / 127$ & 59,8 & $0 / 143$ & 0,0 & $2 / 127$ & 1,6 \\
$>4 *$ & $8 / 698$ & 1,1 & $0 / 698$ & 0,0 & $0 / 698$ & 0,0 \\
\hline
\end{tabular}

* Plantas matrizes mantidas separadas da área de produção comercial

Tabela 8. Incidência do ORSV, do CyMV ou do complexo viral ORSV + CyMV em função da idade das plantas do gênero Phalaenopsis

\begin{tabular}{ccccccc}
\hline \multirow{2}{*}{$\begin{array}{c}\text { Idade } \\
\text { (anos) }\end{array}$} & \multicolumn{5}{c}{$\mathrm{N}^{\circ}$ de plantas infectadas/N de plantas testadas } \\
\cline { 2 - 7 } & ORSV & $\%$ & CyMV & $\%$ & ORSV + CyMV & $\%$ \\
\hline$<1$ & $0 / 59$ & 0,0 & $\frac{1}{1 / 57}$ & 1,8 & $0 / 57$ & 0,0 \\
$1-3$ & $0 / 15$ & 0,0 & $0 / 15$ & 0,0 & $3 / 15$ & 20,0 \\
$>3$ & $6 / 94$ & 6,4 & $29 / 93$ & 31,2 & $30 / 92$ & 32,6 \\
\hline
\end{tabular}




\subsubsection{No orquidário da ESALQ/USP}

A relação detalhada de todas as plantas coletadas no orquidário de coleção da ESALQ/USP e indexadas para a presença de vírus se encontra no Apêndice 2. Uma relação de forma agrupada dos gêneros e híbridos que se mostraram infectados pelo ORSV, pelo CyMV ou pelos dois vírus conjuntamente se encontra na Tabela 9.

Foram amostradas 315 plantas, divididas em 29 gêneros e 23 híbridos intergenéricos. Dentre as 315 orquídeas testadas para a presença do CyMV, 25 mostraram-se infectadas apenas com esse vírus e 33 apresentaram-se infectadas com o CyMV isoladamente ou em complexo com o ORSV, representando respectivamente $7,9 \%$ e $10,5 \%$ das amostras testadas. Das 282 plantas testadas para o ORSV, $23(8,2 \%)$ continham somente este virus e $31(11,0 \%)$ mostraram-se infectadas com o ORSV isoladamente ou com o complexo viral ORSV + CyMV. Nenhuma das 311 plantas indexadas para a presença do CMV, do CyRSV e do DsMV apresentaram resultados positivos. Os gêneros testados que não apresentaram plantas infectadas com pelo menos um dos 5 vírus foram: Aspasia, Bifrenaria, Brassia, Catasetum, Cymbidium, Jumellea, Liparis, Maxillaria, Megaclinium, Octomeria, Odontoglossum, Pleurothallis, Ponera. Sobralia e Trigonidium. 
Tabela 9. Incidência do ORSV, do CyMV e do complexo ORSV + CyMV em gêneros e híbridos de orquideas provenientes do orquidário da ESALQ/USP

\begin{tabular}{|c|c|c|c|c|c|c|}
\hline \multirow[t]{2}{*}{ Gênero } & \multicolumn{6}{|c|}{$\mathrm{N}^{\circ}$ de plantas infectadas $/ \mathrm{N}^{\circ}$ de plantas testadas } \\
\hline & ORSV & $\%$ & CyMV & $\%$ & ORSV+CyMV & $\%$ \\
\hline Bulbophyllum & $0 / 6$ & 0,0 & $1 / 6$ & 16,7 & $1 / 6$ & 16,7 \\
\hline Cattleya & $7 / 48$ & 14,6 & $4 / 61$ & 6,6 & $5 / 48$ & 10,4 \\
\hline Cirrhopetalum & $0 / 2$ & 0,0 & $0 / 2$ & 0,0 & $1 / 2$ & 50,0 \\
\hline Coelogvne & $0 / 13$ & 0,0 & $5 / 13$ & 38,5 & $0 / 13$ & 0.0 \\
\hline Dendrobium & $0 / 10$ & 0,0 & $4 / 10$ & 40,0 & $0 / 10$ & 0,0 \\
\hline Dendrochilum & $0 / 1$ & 0,0 & $1 / 1$ & 100,0 & $0 / 1$ & 0,0 \\
\hline Encyclia & $1 / 18$ & 5,6 & $0 / 18$ & 0,0 & $0 / 18$ & 0,0 \\
\hline Epidendrum & $0 / 14$ & 0,0 & $2 / 15$ & 13,3 & $0 / 14$ & 0,0 \\
\hline Eria & $1 / 3$ & 33,3 & $2 / 3$ & 66,7 & $0 / 3$ & 0,0 \\
\hline Laelia & $5 / 88$ & 5,7 & $3 / 107$ & 2,8 & $0 / 88$ & 0,0 \\
\hline Miltonia & $0 / 5$ & 0,0 & $1 / 5$ & 20,0 & $0 / 5$ & 0. \\
\hline Oncidium & $1 / 4$ & 25,0 & $1 / 4$ & 25,0 & $0 / 4$ & 0,0 \\
\hline Phaius & $0 / 1$ & 0,0 & $0 / 1$ & 0,0 & $1 / 1$ & 100,0 \\
\hline Xylobium & $1 / 1$ & 100,0 & $0 / 1$ & 0,0 & $0 / 1$ & 0,0 \\
\hline Híbridos intergenéricos & $7 / 24$ & 29,2 & $1 / 24$ & 4,2 & $0 / 24$ & 0,0 \\
\hline
\end{tabular}




\subsection{Obtenção de Cymbidium Ayako Tanaka 'Hinodezuru' livre do ORSV}

Testes preliminares para o cultivo "in vitro" dos meristemas mostraram que quando estes eram menores do que $1,0 \mathrm{~mm}$ apresentavam alto índice de oxidação, não sendo possivel recuperá-los. Em função disso os meristemas foram cortados, em sua maioria, com tamanhos em torno de $1,0 \mathrm{~mm}$. Perdas por contaminações fúngicas e bacterianas totalizaram apenas dois frascos. Cada tratamento (Tabela 3) constou de uma média de 6 frascos com um meristema cada.

A primeira repicagem se deu após 40 a 50 dias, dependendo do desenvolvimento dos meristemas. Os PLBs, que já apresentavam início de brotações laterais, foram transferidos para frascos maiores que os iniciais. As repicagens posteriores, num total de 6 , se deram a cada $21( \pm 3)$ dias. Nos tratamentos onde o virazole foi introduzido no meio de subcultivo, este era incluído no meio a cada repicagem.

O transplante e posterior aclimatação de cerca de 1000 plântulas se deu aproximadamente 12 meses após a retirada dos meristemas e essa etapa não ocasionou perda por contaminação ou baixo vigor, resultando em 100\% de pegamento das mesmas. Nessa fase foi realizada a indexação do material transplantado para a detecção do ORSV, através do teste serológico de ELISA e de exames de partículas em suspensão ("leaf dip") no microscópio eletrônico de transmissão. 
Cerca de $10 \%$ das plantas aclimatadas foram testadas para a presença do ORSV. Os resultados (Tabela 10) mostraram que todas as plantas obtidas a partir do tratamento controle (sem adição de virazole nos meios $\mathrm{M}$ e S) continuaram infectadas pelo vírus.

Todos os tratamentos onde o virazole foi introduzido apenas no meio $\mathrm{M}$, com exceção do tratamento $\mathrm{M}-\mathrm{F}-25$, permitiram a regeneração de ao menos uma planta sadia, com variação entre 8,3 e 37,5\% de plantas livres de virus. Quando o virazole foi introduzido nos meios $S$, todos os tratamentos possibilitaram a regeneração de grande quantidade de plantas sem o ORSV, com valores entre $50 \%$ e $100 \%$. O tratamento com 30 ppm de virazole, introduzido nos meios de subcultivos através de filltragem, foi 100\% eficiente na eliminação do vírus do tecido vegetal (Tabela 10). 
Tabela 10. Indexação de plantas de Cymbidium Ayako Tanaka 'Hinodezuru', micropropagadas em meios de cultivo com e sem virazole, para a detecção do ORSV

\begin{tabular}{|c|c|c|}
\hline Tratamento & $\begin{array}{c}\mathrm{N}^{\bullet} \text { de amostras sadias } / \mathrm{N}^{\circ} \text { total } \\
\text { de amostras testadas }\end{array}$ & $\begin{array}{l}\text { Plantas livres } \\
\text { do ORSV }(\%)\end{array}$ \\
\hline Controle & $0 / 8$ & 0,0 \\
\hline M-A-15 & $3 / 12$ & 25,0 \\
\hline$M-F-15$ & $3 / 8$ & 37,5 \\
\hline M-A-20 & $1 / 12$ & 8,3 \\
\hline M-F-20 & $2 / 8$ & 25,0 \\
\hline$M-A-25$ & $4 / 11$ & 36,4 \\
\hline$M-F-25$ & $0 / 5$ & 0,0 \\
\hline S-A-20 & $2 / 3$ & 66,7 \\
\hline S-F-20 & $4 / 6$ & 66,7 \\
\hline S-A-25 & $6 / 7$ & 85,7 \\
\hline S-F-25 & $5 / 7$ & 71,3 \\
\hline S-A-30 & $3 / 6$ & 50,0 \\
\hline S-F-30 & $12 / 12$ & 100,0 \\
\hline \multicolumn{3}{|c|}{$\begin{array}{l}\text { Tratamento controle, onde os meristemas foram cultivados em meio de cultura sem } \\
\text { adição de virazole em qualquer fase do seu desenvolvimento, Virazole adicionado apenas } \\
\text { ao meio para meristema }(\mathrm{M}) \text {, virazole adicionado apenas aos meios de subcultivo (S), } \\
\text { virazole autoclavado juntamente com o meio de cultivo }(\mathrm{A}) \text {, virazole introduzido através } \\
\text { de filtragem no meio de cultivo previamente autoclavado }(\mathrm{F})\end{array}$} \\
\hline
\end{tabular}




\section{DISCUSSÃO}

\subsection{Diagnóstico de viroses em orquídeas}

As observações dos sintomas em orquídeas mostraram o que é amplamente comentado na literatura, que algumas plantas infectadas com um ou mais vírus permanecem assintomáticas enquanto outras sadias podem apresentar sintomas facilmente confundidos com aqueles provocados por esses patógenos (Stephens, 1964; Wisler, 1989; Lawson, 1995). Observa-se através de inúmeras publicações que há uma grande preocupação especialmente com a presença de plantas infectadas e assintomáticas nas áreas de cultivo (Lawson \& Hearon, 1973; Sheehan, 1980; Wisler, 1989; Lawson \& Hsu, 1995) por serem, muitas vezes, responsáveis pela introdução do vírus na área de produção. No entanto, poucos trabalhos mostram com que frequência, em quais gêneros ou para quais vírus há maior incidência dessas plantas.

Lawson \& Hsu (1995) comentaram que plantas doentes podem permanecer assintomáticas, principalmente quando infectadas pelo ORSV. Essa característica foi observada no presente estudo, não apenas em plantas infectadas com o ORSV, mas também com o CyMV ou mesmo com o complexo viral ORSV + CyMV. 
A Tabela 4 mostra que gêneros como Laelia e Phalaenopsis apresentaram $75 \%$ e $60 \%$, respectivamente, de plantas assintomáticas infectadas com o ORSV. Quando infectadas com o CyMV a incidência de plantas desses gêneros assintomáticas foi de $20 \%$ e $28 \%$, respectivamente. Analogamente, enquanto gêneros como Dendrobium apresentaram 58,3\% de plantas infectadas com o CyMV e assintomáticas, outros como Cattleya tiveram 100\% das plantas com sintomas visíveis quando contaminadas pelo mesmo vírus. Embora seja conhecido que as condições climáticas exercem influência sobre a manifestação de sintomas de vírus em orquídeas (Wisler, 1989; Lawson \& Hu, 1995 ) no presente estudo verificou-se que a frequência de plantas com sintomas visíveis parece estar relacionada principalmente com o gênero da planta, visto que as condições climáticas eram semelhantes.

A confusão na identificação dos vírus em orquídeas através dos sintomas não se restringe apenas às plantas doentes e assintomáticas. Verificou-se nesse estudo que alguns gêneros de orquideas, quando infectados por vírus, podem apresentar sintomas que muitas vezes estão associados a outros fatores. Dois exemplos desse fato foram observados nos gêneros Cymbidium e Phalaenopsis. No primeiro verificou-se que as plantas infectadas com o ORSV podem apresentar amarelecimento generalizado das folhas, semelhante à defíciência de nitrogênio, enquanto em Phalaenopsis, as plantas infectadas com o mesmo vírus exibem avermelhamento do limbo, facilmente confundido com a pigmentação normal das folhas. O contato com produtores de Cymbidium mostrou que há um total desconhecimento de que esses sintomas poderiam, em alguns casos, estar relacionados com a presença do ORSV nas plantas, de onde o virus seria facilmente disseminado na área de produção. 
Outros fatores como infecção por fungos, danos de insetos, características genéticas ou ambientais, como poluição atmosférica ou excesso de intensidade luminosa, também podem ser facilmente confundidos com aqueles provocados por vírus em orquídeas (Stephens, 1964; Lawson, 1995). O mesmo foi observado no presente estudo, conforme apresentado na Tabela 4. Notou-se que praticamente todos os gêneros de orquideas analisados apresentaram elevada incidência de plantas com algum tipo de sintoma, porém encontravam-se livres dos virus estudados. A porcentagem de plantas sadias com sintomas variou de $31,6 \%$ para o gênero Cymbidium a $90,2 \%$ para o gênero Laelia. No entanto, não se pode descartar a possibilidade de que alguns desses sintomas estejam associados à infecção com virus que não foram estudados nesse trabalho, ou até algum virus ainda não descrito em plantas de orquideas. Esses resultados sugerem que plantas sadias, de interesse econômico e que poderiam servir como matrizes são muitas vezes descartadas pelos produtores por apresentarem suspeitas de estarem infectadas por vírus.

Sabe-se que a associação precisa entre a presença de sintomas e a ocorrência de vírus em orquideas é uma tarefa difícil. No entanto, alguns gêneros apresentam respostas constantes à infecção com o ORSV, o CyMV ou ambos e uma vez reconhecidos estes sintomas, deve-se promover a eliminação ou separação das plantas doentes da área de produção, conforme sugerido por Wisler (1989) e Lawson (1995). Deve-se lembrar porém que, apesar dos sintomas poderem indicar a presença de algum desses virus nas plantas observadas, a comprovação dessa suspeita só será obtida após a utilização de testes de indexação biológica, serológica ou de microscopia eletrônica. 
Apesar dos três tipos de testes de indexação terem sido eficientes para o diagnóstico de plantas infectadas, especialmente com o ORSV e o CyMV, utilizou-se principalmente o teste de ELISA, devido a sua praticidade e rapidez na obtenção dos resultados. Notou-se, porém, que a sua utilização requer cuidado especial com os controles negativos (extratos de plantas sadias), de tal sorte que não haja interpretações errôneas dos resultados de absorbância a $405 \mathrm{~nm}$. Um bom exemplo disso refere-se às plantas do gênero Cattleya que por sofrerem rápida oxidação de seus tecidos durante a extração do suco celular, apresentam valores médios de absorbância cerca de duas vezes mais altos do que os de plantas de gêneros como Cymbidium ou Phalaenopsis, podendo levar a falsos positivos. Para o caso de produtores que queiram indexar suas plantas, especialmente para os dois vírus mais comuns nos cultivos, o teste biológico pode ser o mais adequado, principalmente por ser de baixo custo e fácil execução.

Apesar do ORSV e do CyMV terem sido encontrados no orquidário da ESALQ e em 13 dos 16 municípios analisados (com exceção de Santa Isabel, São José dos Campos e Valinhos, onde apenas uma planta foi analisada, não correspondendo assim a um número significativo de amostras), o mesmo não ocorreu com os demais vírus testados nesse levantamento, uma vez que o CMV, o CyRSV e o DsMV não foram encontrados em nenhuma planta. Como o CyRSV e o DsMV ainda não foram relatados em orquideas no Brasil, provavelmente esses vírus não ocorram em nossas condições. Embora o CMV tenha sido descrito infectando orquideas em São Paulo (Nóbrega, 1947), a sua incidência deve ser extremamente baixa, uma vez que aparentemente esse vírus não foj mais relatado em plantas dessa família no pais. 
Dois padrões distintos de rhabdovirus foram encontrados no presente trabalho, sendo que um deles era semelhante ao do OFV, enquanto o outro assemelhava-se ao vírus da leprose dos citros "Citrus leprosis virus" - CLV (Colariccio et al., 1995). É interessante ressaltar que o padrão de partículas do tipo OFV já havia sido relatado em orquídeas no Brasil (Kitajima et al., 1974), enquanto o segundo padrão de partículas foi encontrado pela primeira vez em orquídeas no presente trabalho, sendo que Kitajima et al. ${ }^{8}$ sugerem que essas partículas podem representar um outro rhabdovirus infectando orquídeas, ou ainda uma forma em diferente nível de maturação dos virions de OFV.

\subsection{Incidência das viroses}

Os resultados obtidos mostram que, conforme o esperado, o ORSV e o CyMV foram os vírus preponderantes nos cultivos de orquídeas em diferentes regiões do Estado de São Paulo, estando presentes tanto em cultivos particulares como no de coleção. A incidência desses dois vírus nos orquidários comerciais e da ESALQ foi de aproximadamente $10 \%$ e não diferiu muito dos valores encontrados por GonzálezSegñana (1989), em levantamento do orquidário da Universidade Federal de Viçosa, onde encontrou $8 \%$ das plantas infectadas pelo ORSV. Os resultados comparativos entre incidências de ORSV e CyMV, no entanto, diferiram daqueles observados em outros levantamentos realizados na América Latina, nos Estados Unidos e em Cingapura (Zettler et al., 1978; Wisler et al., 1979; Wisler, 1981; Hu et al., 1993; Wong et al., 1994). Nesses paises há relatos de incidências bem superiores do CyMV em relação ao

\footnotetext{
${ }^{8}$ KITAJIMA, E.W.; REZENDE, J.A.M.; FREITAS, J.C. Two types of particles associated with lesions induced by Brevipalpus mites in different plant hosts. Trabalho a ser apresentado ao VIII ENCONTRO NACIONAL DE VIROLOGIA, São Lourenço, nov. 1996.
} 
ORSV, podendo atingir valores até 10 vezes maiores (Zettler et al., 1978; Wong et al., 1994).

Uma diferença interessante observada entre os dois tipos de orquidários amostrados, diz respeito a variação nas incidências do ORSV e do CyMV entre os diferentes gêneros. Nos orquidários particulares, as maiores incidências desses vírus foram encontradas em gêneros com alto valor comercial, enquanto na coleção da ESALQ, aparentemente ambos estavam mais homogeneamente distribuídos em maior número de gêneros de orquídeas. Assim, no levantamento realizado nos orquidários particulares, 33 dos 47 gêneros analisados (70,2\%) não apresentaram o ORSV e o CyMV em nenhuma amostra, enquanto 15 dos 29 gêneros amostrados no orquidário da ESALQ $(51,7 \%)$ apresentaram todas as plantas sadias. Essa variação pode estar relacionada com a diferença na quantidade de tratos culturais que as plantas receberam. Essa observação concorda com Wisler (1989), que verificou em orquidários comerciais que as plantas de menor interesse econômico são apenas ocasionalmente propagadas e suas flores raramente colhidas, recebendo assim menor quantidade de práticas culturais e portanto apresentando menor chance de serem infectadas. No caso do orquidário de coleção da ESALQ, mesmo os gêneros de orquídeas menos valorizados economicamente recebem os mesmos cuidados daqueles mais importantes comercialmente, resultando em incidências semelhantes de vírus em maior número de gêneros. Exemplos desse fato são as plantas dos gêneros Phaius e Xylobium, de pouco valor econômico e que foram coletadas dos dois tipos de orquidários, mostrando-se infectadas com o ORSV e o CyMV apenas as provenientes do cultivo da ESALQ. 
Observou-se também neste trabalho que aparentemente há uma relação entre o gênero de orquídea analisado e a espécie de vírus encontrada, especialmente em orquidários comerciais. Assim, verificou-se que plantas de Cymbidium mostraram incidências de até $59,8 \%$ para o ORSV, enquanto apresentaram incidências próximas a zero para o CyMV. Tal resultado concorda com aquele relatado por Wisler (1981), onde foram encontradas incidências de $57,1 \%$ e $5,7 \%$ para o ORSV e o CyMV, respectivamente. A autora comenta que o gênero Cymbidium normalmente apresenta maior número de plantas infectadas com o ORSV do que com o CyMV, porém afirma que a causa para esse fato ainda é desconhecida. A hipótese levantada é que esse fato possa estar relacionado com a temperatura, uma vez que apenas os cymbidiums cultivados em temperaturas amenas apresentam tal característica, enquanto os de clima mais quente não seguem o mesmo padrão de infecção. A autora sugere ainda que esse resultado pode estar associado a diferenças genéticas ou regionais.

Uma outra hipótese para explicar essa diferença, com base nas observações feitas no presente trabalho, relaciona-se a manifestação de sintomas desses dois vírus nas plantas de Cymbidium. Nenhuma flor de Cymbidium analisada e infectada com o ORSV apresentou qualquer tipo de sintoma e, apesar desse vírus induzir o aparecimento de sintomas nas folhas, na maioria dos casos estes eram semelhantes aqueles provocados por deficiência de nitrogênio, podendo passar sem serem percebidos na área de produção. Por outro lado, plantas de Cymbidium infectadas pelo CyMV apresentavam necrose foliar bastante evidente, fazendo com que naturalmente o produtor as eliminasse, enquanto mantinha outras com o ORSV, sem saber que estavam doentes. 
No entanto, quando são desconsideradas as plantas do gênero Cymbidıum do total de plantas amostradas no presente estudo, obtêm-se valores bastante diferentes na incidência do ORSV e do CyMV, que passam para $13,2 \%$ e $28,7 \%$, respectivamente nos orquidários particulares. Assim, os dados assemelham-se aqueles apresentados em inúmeros trabalhos de levantamentos de viroses em orquídeas realizados em todo o mundo, com incidência do CyMV superior a do ORSV (Zettler et al., 1978; Wisler et al., 1979; Wisler, 1981; Hu et al., 1993; Wong et al., 1994).

Outro fator que parece estar intimamente relacionado com a incidência de vírus em orquídeas é a idade da planta, ou melhor, o tempo que a planta permanece na área de produção. Análises de plantas dos gêneros Cymbidium e Phalaenopsis provenientes de um orquidário comercial do município de Atibaia, SP, exemplificam esse fato de maneira bastante clara. Considerando-se as 893 plantas de Cymbidium indexadas para o ORSV, verificou-se que as plantas novas, recém introduzidas na produção, encontravam-se praticamente livres de vírus. No entanto, à medida que eram analisadas plantas com mais idade, notava-se que a incidência da doença aumentava proporcionalmente, conforme a quantidade de tratos culturais que as plantas recebiam. Essa incidência crescente de vírus em função da idade da planta, no entanto, não era observada nas plantas matrizes que, apesar de serem mais velhas ( $>4$ anos), eram mantidas em estufas separadas da produção comercial, tendo com isso menor chance de serem infectadas por instrumentos de corte contaminados. Tal observação reforça ainda mais a intima relação entre incidência de vírus e quantidade de tratos culturais a que as plantas são submetidas. Deve-se salientar porém que mesmo a baixa incidência de matrizes infectadas por vírus, pode se tornar um 
problema sério para a produção, visto que a propagação dessas plantas pode disseminar o vírus na área, a exemplo do que ocorreu com a variedade Ayako Tanaka 'Hinodezuru'

Um outro exemplo da relação entre a incidência de vírus e a idade da planta foi observado no gênero Phalaenopsis. Das 168 plantas testadas observaram-se incidências crescentes do ORSV, do CyMV e principalmente da infecção mista, conforme eram avaliadas plantas mais velhas (Tabela 8). De maneira análoga ao que ocorreu com as plantas de Cymbidium, o aumento na idade das plantas e por consequência a maior quantidade de operações de cultivo a que as plantas estavam sujeitas, parece ter favorecido a disseminação dos vírus. Resultados semelhantes foram encontrados por inúmeros autores (Zettler et al., 1978; Wisler et al., 1979; Wisler, 1981; Okemura et al., 1984; Hu et al., 1993 e Wong et al., 1994), em vários paises e para diversos gêneros de orquideas, evidenciando a importância dos tratos culturais na disseminação dos principais virus de orquídeas.

\subsection{Controle das viroses em orquídeas}

Com base nos principais sintomas de virus associados aos principais gêneros de orquideas e principalmente através dos testes de indexação das plantas, supõe-se que os produtores possam estabelecer cultivos de orquídeas livres de vírus. A grande porcentagem de plantas naturalmente sadias encontradas nas produções (próximo a $90 \%$ ), indica que, uma vez identificadas, essas plantas podem servir como matrizes sem que haja a necessidade de tratamento adicional para esse propósito. Além disso, sabe-se que o ORSV e o CyMV não são transmitidos pelas sementes de orquídeas infectadas 
(Wisler et al., 1979; Zettler et al., 1987), fazendo com que a produção de mudas através dessa prática seja recomendada sempre que possivel.

No entanto, caso o produtor possua uma variedade de interesse comercial que se encontre $100 \%$ infectada, principalmente com o ORSV, os estudos realizados mostraram ser possivel a obtenção de plantas sadias, que poderão servir como matrizes, através da associação do cultivo de meristemas e a quimioterapia, já recomendada por Albouye et al. (1988), Loi et al. (1991) e Toussaint et al. (1993). A diferença entre esses estudos anteriores e o presente trabalho reside na tentativa de tornar a técnica mais acessivel a produtores que possuem laboratórios particulares, através da simplificação das operações "in vitro" e redução dos custos. Assim, procurou-se evitar que o virazole fosse introduzido através de filtragem no meio de cultivo, testando a sua autoclavagem juntamente com os demais componentes do meio e procurou-se evitar também a reposição frequente do produto nos meios de subcultivo $(\mathrm{S})$ através da sua introdução apenas no meio de cultivo para meristemas (M).

Os resultados obtidos confirmaram a eficiência do ribavirin na eliminação do ORSV de plantas de orquideas infectadas (Albouye et al., 1988; Loi et al., 1991; Toussaint et al., 1993) e indicaram que as tentativas de simplificação da técnica parecem promissoras. No entanto, uma vez que apenas o tratamento com $30 \mathrm{ppm}$ de virazole filtrado e introduzido nos meios S mostrou-se $100 \%$ efetivo na limpeza do ORSV de meristemas de Cymbidium, sugere-se que a eficiência da técnica parece estar relacionada principalmente com a concentração do produto. Outros aspectos que também podem interferir na eficiência da limpeza de vírus são o número de subcultivos em que o material vegetal está em contato com o produto, o isolamento de novos PLBs sempre que 
possivel, a sensibilidade do vírus ao virazole (Toussaint et al., 1993), a planta e até o tipo de tecido vegetal propagado (Loi et al., 1991), além de seu tamanho (Ishii, 1974; Inouye, 1984).

É importante salientar que a utilização dessa técnica deve ser sempre acompanhada de testes de indexação para se verificar a sanidade das plantas regeneradas, pois os resultados mostraram que apesar da possibilidade da eliminação de vírus do tecido vegetal, a porcentagem de plantas sadias é bastante variável (Tabela 10). Além disso, Toussaint et al. (1993) mostraram que deve ser procedida uma indexação prolongada das plantas obtidas a partir dessa técnica, uma vez que o resultado negativo na indexação logo após a aclimatação das plantas pode ser mascarado devido a baixa concentração do vírus no tecido vegetal, sendo que após um período variável de tempo e a continuada replicação do vírus, uma planta indexada e inicialmente negativa, pode mostrar-se positiva mais tarde.

É sempre importante lembrar que uma vez que os principais vírus de orquídeas, especialmente o ORSV e o CyMV, não apresentam vetores conhecidos e são disseminados basicamente através da propagação vegetativa ou por instrumentos de corte, devem-se tomar cuidados durante essas duas etapas da produção. Dessa forma, através da utilização de matrizes sadias e higienização dos tratos culturais das plantas, torna-se possivel manter uma produção de orquídeas livres, ou ao menos com baixa incidência de vírus, conforme comentado por Sproles (1983), que afirma ter reduzido drasticamente a incidência de vírus de seu orquidário após um período de 4 anos de adoção dessas medidas. Assim, como comenta Wisler (1989), pode-se lutar contra os vírus em orquídeas... e vencê-los ! 


\section{CONCLUSÕES}

Diante dos resultados obtidos concluiu-se que:

a) O ORSV e o CyMV foram os virus preponderantes, encontrados tanto em orquidários particulares quanto no de coleção da ESALQ/USP;

b) Dois padrões distintos de partículas e inclusões citoplasmáticas de rhabdovirus foram encontrados em alguns gêneros de orquídeas;

c) O CMV, o CyRSV e o DsMV não foram encontrados nas amostras de orquídeas examinadas;

d) O aumento da incidência dos principais vírus encontrados em orquideas está diretamente relacionado com a idade das plantas, sendo uma função dos tratos culturais recebidos;

e) A associação entre o cultivo de meristemas e a quimioterapia mostrou-se eficiente para a obtenção de matrizes de Cymbidium livres do ORSV. 


\section{REFERÊNCIAS BIBLIOGRÁFICAS}

ALBOUY, J.; FLOUZAT, C.; KUSIAK, C.; TRONCHET, M. Eradication of orchid viruses by chemotherapy from in-vitro cultures of Cymbidium. Acta Horticulturae, v. 234, p. $413-420,1988$.

BAPTISTA, C.R. Efeito terapêutico de virazole sobre os virus causadores do enrolamento da folha da videira, anel do pimentão e tristeza dos citros. Campinas, 1995. 85p. Dissertação (Mestrado) - Universidade Estadual de Campinas.

BATCHELOR, S.R. Your first orchid - diseases and insects. American Orchid Society Bulletin, v.62, n.11, p.1142-1149, Nov. 1993.

BICALHO, H.D. Orquídeas. In: SIMPÓSIO BRASILEIRO DE FLORICULTURA E PLANTAS ORNAMENTAIS, 1., Maringá, 1992. Manual de Floricultura. Maringá: UEM, 1992. p. 212-214.

BODNARUK, W.H.; HENNEN, G.R.; ZETTLER, F.W.; SHEEHAN, T.J. Incidence of Cymbidium mosaic and Odontoglossum ringspot viruses in wild and cultivated orchids of the Cattleya Alliance surveyed in Florida. American Orchid Society Bulletin, v.48, n.1, p.26-27, Jan. 1979.

CASSELLS, A.C.; LONG, R.D. The elimination of potato viruses $\mathrm{X}, \mathrm{Y}, \mathrm{S}$ and $\mathrm{M}$ in meristem and explant cultures of potato in the presence of Virazole. Potato Research, v.25, p.165-173, 1982. 
CHAGAS, C.M.; LOEKMANWIDJAJA, T.; GALLETI, S.R. Partículas do tipo rhabdovirus em duas espécies de orquídeas. In: Congresso Brasileiro de Fitopatologia, 21., 1988. Resumos. Fitopatologia Brasileira, v.13, n.2, p.100, jul. 1988.

CHAGAS, C.M.; NORONHA, A.; JULY, J.R. Ocorrência de um complexo viral em Cymbidium no Brasil. O Biológico, v.43, n.3/4, p.72-77, 1977.

CHAGAS, C.M.; COLARICCIO, A.; GAlETTI, S.R.; KITAJIMA, E.W. Infecção natural de Amorphophallus konjac pelo vírus do mosaico do inhame no Brasil. Fitopatologia Brasileira, v.18, n.4, p551-554, dez. 1993.

CHANG, M.U. Researches on virus diseases of ornamental plants in Korea. Korean Journal of Plant Pathology, v.3, n. 1, p.35-42, Jan. 1987.

CHEPLICK, S.M.; AGRIOS, G.N. Effect of injected antiviral compounds on apple mosaic, scar skin, and dapple apple diseases of apple trees. Plant Disease, v.67, n. 10, p.1130-1133, 1983.

CHIA, T.F.; CHAN, Y.S.; CHUA, N.H. Detection and localization of viruses in orchids by tissue-print hybridization. Plant Pathology, v.41, p.355-361, 1992.

CLIFFORD, H.T. Immunodiffusion techniques for the detection of the Cymbidium mosaic and Odontoglossum ringspot viruses of orchids. Gainesville, 1977. 62p. Dissertation (M.S.) - University of Florida.

COLARICCIO, A.; LOVISOLO, O.; CHAGAS, C.M.; GALLETI, S.T.; ROSSETTI, V.; KITAJIMA, E.W. Transmissão mecânica e aspectos ultraestruturais da leprose dos citros. Fitopatologia Brasileira, v.20, n.2, p.208-213, jun. 1995. 
DE CLERCQ, E.; LUCZAK, M. Fluorimidazoles as antiviral agents and inhibitors of polynucleotide biosynthesis. Life Science, v.17, p.187-194, 1975.

DE FAZIO, G.; KUDAMATSU, M.; VICENTE, M. Virazole pre-treatments for the prevention of tomato spotted wilt virus (TSWV) systemic infection in tobacco plants, Nicotiana tabacum L. "white burley". Fitopatologia Brasileira, v.5, n.3, p.343-349, Oct. 1980.

ELLIOTT, M.S.; ZETTLER, F.W.; SHEEHAN, T.J.; WISLER, G.C. A virus disease of Dendrobium in Florida. American Orchid Society Bulletin, v.56, n.10, p.10521053, Oct. 1987.

FRANCKI, R.I.B. Cymbidium mosaic virus. Kew: C.M.I./C.A.B./A.A.P., 1970. n.p. (C.M.I./A.A.B. Descriptions of Plant Viruses, 27).

FRANCKI, R.I.B.; MOSSOP, D.W.; HATTA, T. Cucumber mosaic virus. Kew: C.M.I./C.A.B./A.A.B., 1979. n.p. (C.M.I./A.A.B. Descriptions of Plant Viruses, 213). FREITAS, J.C.; ELLIOTT, M.S.; ZETTLER, F.W. Virus detected in a collection of orchid maintained for more than 50 years in Florida. In: Congresso Brasileiro de Fitopatologia, 28., 1995. Resumos. Fitopatologia Brasileira, v.20 (supl.), p.292, 1995.

FREYTAG, A.H. A "hot knife" to prevent virus spread in orchids. American Orchid Society Bulletin, v.34, n.6, p.501-502, June 1965 
GONZÁLEZ-SEGÑANA, L.R.G. Propriedades de um isolado do vírus da mancha anelar do Odontoglossum e a sua detecção em orquídeas. Viçosa, 1989. 56p. Dissertação (M.S.) - Universidade Federal de Viçosa.

HAMILTON, R.I.; VALENTINE, B. Infection of orchid pollen by odontoglossum ringspot and cymbidium mosaic viruses. Canadian Journal of Plant Pathology, v.6, n.3, p.185-190, Sept. 1984

HAMMOND, J.; LAWSON, R.H. A strain of bean yellow mosaic virus is aphidtransmitted from orchid. Acta Horticulturae, v.234, p.365-369, 1988.

HOLLINGS, M.; STONE, O.M.; BARTON, R.J. Pathology, soil transmission and characterization of cymbidium ringspot, a virus from Cymbidium orchids and white clover (Trifolium repens). Annual Applied Biology, v.85, p.365-370, 1977.

HU, L.S.; FERREIRA, S. Orchid viruses - detection, transmission and management of cymbidium mosaic and odontoglossum rinsgpot viruses in dendrobium in Hawaii. American Orchid Society Bulletin, v.63, n.8, p.896-898, Aug. 1994.

HU, J.S.; FERRERA, S.; WANG, M.; BORTH, W.B.; MINK, G.; JORDAN, R. Purification, host range, serology, and partial sequencing of dendrobium mosaic potyvirus, a new member of the bean common mosaic virus subgroup. Phytopathology, v.85, n.5, p.542-546, 1995.

HU, J.S.; FERREIRA, S; WANG, M.; XU, M.Q. Detection of cymbidium mosaic virus, odontoglossum ringspot virus, tomato spotted wilt virus, and potyviruses infecting orchids in Hawaii. Plant Disease, v.77, n.5, p.464-468, May 1993. 
HU, J.S.; FERREIRA, S.; XU, M.Q.; LU, M.; IHA, M.; PFLUM, E.; WANG, M. Transmission, movement and inactivation of cymbidium mosaic and odontoglossum ringspot viruses. Plant Disease, v.78, n.6, p.633-636, 1994.

HU, J.S.; WANG, M.; FERREIRA, S.; OGATA, D. Tomato spotted wilt virus on Oncidium orchids in Hawaii. Plant Disease, v.76, n.4, p.426, 1992.

INOUYE, N. Some experiments on the transmission of cymbidium mosaic virus and odontoglossum ringspot virus: abstract. Nogaku Kenkyu, v.52, n.2, p.90, 1968.

INOUYE, N. Cucumber mosaic virus isolated from Dendrobium: abstract. Nogaku Kenkyu, v.53, n. 1/2, p.60, 1969.

INOUYE, N. Effect of antiserum treatment on the production of virus-free Cymbidium by means of meristem culture: abstract. Nogaku Kenkyu, v.60, n.3, p.132-133, 1984. INOUYE, N.; LEU, L.S. Survey on the viruses in orchids in Taiwan: abstract. Nogaku Kenkyu, v.60, n.2, p. 105, 1983.

ISHII, M. Partial elimination of virus from double infected orchids by mersitem explant culture. Acta Horticulturae, v.36, p. 229-233, 1974.

JENSEN, D.D. Mosaic and black streak disease of Cymbidium orchids. Phytopathology, v.41, n.5, p.401-414, May 1951.

JENSEN, D.D. Orchid disorders, with special reference to virus diseases. American Orchid Society Bulletin, v.24, n. 11, p.756-766, Nov. 1955. 
JENSEN, D.D.; GOLD, A.H. A virus ringspot of Odontoglossum orchid: symptoms, transmission, and electron microscopy. Phytopathology, v.41, n.7, p.648-653, July 1951.

KITAJIMA, E.W.; BLUMENSCHEIN, A. ; COSTA, A.S. Rodlike particles associated with ringspot symptoms in several orchid species in Brazil. Phytopathologische Zeitschrift, v.81, n.3, p.280-286, Nov. 1974.

KITAJIMA, E.W.; RIBEIRO, R.L.D.; LIN, M.T.; RIBEIRO, M.I.S.D.; KIMURA, O.; COSTA, C.L.; PIMENTEL, J.P. Lista comentada de vírus e organismos do tipo micoplasma em plantas cultivadas e silvestres do estado do Rio de Janeiro. Fitopatologia Brasileira, v.9, n. 3, p.607-625, out. 1984.

KLEIN, R.E.; LIVINGSTON, C.H. Eradication of potato viruses $\mathrm{X}$ and $\mathrm{S}$ from potato shoot-tip cultures with ribavirin. Phytopathology, v.73, n.7, p. 1049-1050, 1983.

$\mathrm{KO}$, N.J. Cytological methods for the detection, identification, and charaterization of orchid viruses and their inclusion bodies. Gainesville, 1985. 82p. Thesis (Ph.D.) University of Florida.

KOBAYASHI, R.S.; KAMEMOTO, H. Inheritance of floral necrosis in Dendrobium induced by cymbidium mosaic virus. Hort Science, v.24, n.3, p.499-500, 1989.

LAWSON, R.H. Chemical inactivation of cymbidium mosaic and odontoglossum ringspot viruses. American Orchid Society Bulletin, v.36, n.11, p.998-1001, Nov. 1967. 
LAWSON, R.H. Viruses and their control. In: AMERICAN ORCHID SOCIETY. Orchid pests and diseases. West Palm Beach, 1995. cap 6, p. 74-104.

LAWSON, R.H.; HEARON, S.S. Symptomatology of Cattleya mericlones infected with cymbidium mosaic virus. American Orchid Society Bulletin, v.42, n.12, p.10711074, Dec. 1973.

LAWSON, R.H.; HEARON, S.S. Distribution and staining properties of cymbidium mosaic virus in buds of Cattleya orchids. Acta Horticulturae, v.36, p. 195-206, 1974.

LAWSON, R.H.; HSU, H. Orchid. In: LOEBENSTEIN, G.; LAWSON, R.H.; BRUNT, A.A., (Ed.) Virus and virus-like diseases of bulb and flower crops. West Sussex: John Wiley \& Sons, 1995. cap.36, p.409-420.

LESEMANN, D.E. Long, filamentous virus-like particles associated with vein necrosis of Dendrobium phalaenopsis. Phytopathologische Zeitschrift, v.71, n.3, p.257-269, July 1977.

LOI, J.S.; LEE, S.M.; LAM-CHAN, L.T.; FAN, S.; YIANG, W.H. Eradication of orchid viruses in Dendrobium Sonia using virazole. Singapore Journal of Primary Industry, v. 19, n.1, p. 16-22, 1991.

MAUGH II, T.H. Chemotherapy: Antiviral agents come of age. Science, v.192, n.4235, p.128-132, 9 Apr. 1976. 
MAYHEW, D.E.; COOKE, A.L.; RAABE, R.D. Special report. A new virus is reported for Phalaenopsis. American Orchid Society Bulletin, v.61, n.6, p.574-577, June 1992.

MOREL, G.M. Producing virus-free Cymbidiums. American Orchid Society Bulletin, v.29, n.7, p.495-7, July 1960.

MOWAT, W.P.; DAWSON, S. Detection and identification of plant viruses by ELISA using crude sap extracts and unfractionated antisera. Journal of Virological Methods, v.15, p.233-247, 1987.

NAMBA, R.; ISHII, M. Failure of aphids (Myzus persicae and Cerataphis orchidearum) to transmit the odontoglossum ringspot and cymbidium mosaic viruses to orchid plantlets derived from meristem cultures. Phytopathology, v.61, n.5, p.582-583, 1971.

NÓBREGA, N.R. Uma doença de vírus em orquídea. O Biológico, v.13, p.62, 1947.

OKEMURA, A.K.; KAMEMOTO, H.; ISHII, M. Incidence and expression of cymbidium mosaic virus in Dendrobium hybrids. Hawaii Institute of Tropical Agriculture and Human Resources Research Extention Service, n.33, p.3-13, Aug. 1984.

PAUL, H.L. Odontoglossum ringspot virus. Kew: C.M.I./C.A.B./A.A.B., 1975. N.p. (C.M.I./A.A.B. Descriptions of Plant Viruses, 155). 
PEARSON, M.N.; COLE, J.S. The effects of cymbidium mosaic virus and odontoglossum ringspot virus on the growth of cymbidium orchids. Journal of Phytopathology, v.117, p.193-197, 1986.

PÉREZ, J.E.; CORTÉS-MONLLOR, A. Survey for the presence of tobacco mosaic, cymbidium mosaic and other viruses in orchids. Journal of Agriculture of University of Puerto Rico, v.44, p. 138-149, 1960.

PIERIK, R.L.M. In vitro culture of higher plants. Dordrecht: Martinus Nijhoff Publ., 1987. 344p.

PUGSLEY, A.T. The use of trisodium phosphate as an inactivating agent for plant viruses. Journal of the Australian Institute of Agricultural Science, p.41-3, Mar. 1952

RODRIGUES, M.G.R.; KITAJIMA, E.W.; LIN, M.T. Mosaico em aráceas comestíveis e ornamentais, causado pelo vírus do mosaico do inhame ("Dasheen mosaic virus") Fitopatologia Brasileira, v.9, p.291-299, jun. 1984.

SHEEHAN, T.J. Orchids. In: LARSON, L.A. (Ed.) Introduction to floriculture. New York: Academic Press, 1980. cap.5, p.133-164.

SILVA, D.M.; NOGUEIRA, N.L. Efeito dos viricidas virazole e OAG-370 sobre os vírus da necrose branca do fumo e vira cabeça do tomateiro. In: Congresso Paulista de Fitopatologia, 6., 1983. Resumos. Summa Phytopathologica, v.9, n.1/2, p.36, jan./jun. 1983. 
SILVA, D.M.; NOGUEIRA, N.L.; GOMES, J.E. Mecanismo de ação do virazole sobre o vírus "vira cabeça" do tomateiro em feijoeiro. ln: Congresso Paulista de Fitopatologia, 10., 1987. Resumos. Summa Phytopathologica, v.13, n.1/2, p.28, jan.jjun. 1987.

SILVA, W. O cultivo de orquídeas no Brasil. 6.ed. São Paulo: Nobel, 1986. 96p.

SIMPKINS, I.; WALKEY, D.G.A.; NEELY, H.A. Chemical suppression of virus in cultured plant tissues. Annual Applied Biology, v.99, p.161-169, 1981.

SPROLES, E.T. An effort to eradicate cymbidium mosaic and odontoglossum ringspot viruses from a private collection - results of a four-year study. American Orchid Society Bulletin, v.52, n.3, p.261-265, Mar. 1983.

STEPHENS, J.A. How serious are orchid viruses? American Orchid Society Bulletin, v.32, n.1, p.17-19, Jan, 1964.

STREETER, D.G.; WITKOWSKI, J.T.; KHARE, G.P.; SIDWELL, R.W.; BAUER, R.J.; ROBINS, R.K.; SIMON, L.N. Mechanism of action of 1- $\beta$-D-ribofuranosyl-1,2,4triazole-3-carboxamide (Virazole), a new broad spectrum antiviral agent. Proceedings of the National Academy of Sciences USA, v.70, p.1174-1178, Jan./Dec. 1973.

SUTULA, C.L.; GILLETT, J.M.; MORRISSEY, S.M.; RAMSDELL, D.C. Interpreting ELISA data and establishing the positive-negative threshold. Plant Disease, v.70, p.722-726, 1986. 
TOUSSAINT, A.; KUMMERT, J.; MAROQUIN, C.; LEBRUN, A.; ROGGEMANS, J. Use of virazole to eradicate odontoglossum ringspot virus from in vitro cultures of Cymbidium Sw. Plant Cell, Tissue and Organ Culture, v.32, p.303-309, 1993.

WISLER, G.C. Development of serological techniques designed to index cymbidium mosaic and odontoglossum ringspot viruses in commercial orchids. Gainesville, 1981. 46p. Dissertation (M.S.) - University of Florida.

WISLER, G.C. How to control orchid viruses. Gainesville: Maupin House Publ., 1989. $118 \mathrm{p}$

WISLER, G.C.; ZETTLER, F.W.; MU, L. Virus infections of Vanilla and other orchids in French Polynesia. Plant Disease, v.71, n.12, p.1125-1129, Dec. 198?a.

WISLER, G.C.; ZETTLER, F.W.; MU, L. Viruses infecting Vanilla in French Polynesia. American Orchid Society Bulletin, v.56, n.4, p.381-387, Apr. 1987b.

WISLER, G.C.; ZETTLER, F.W.; SHEEHAN, T.J. Relative incidence of Cymbidium mosaic and Odontoglossum ringspot viruses in several genera of wild and cultivated orchids. Proceedings of the Florida State Horticultural Society, v.92, p.339-340, 1979.

WISLER, G.C.; ZETTLER, F.W.; SHEEHAN, T.J. A diagnostic technique developed for orchid growers to detect cymbidium mosaic and odontoglossum ringspot viruses American Orchid Society Bulletin, v.52, n.3, p.255-261, Mar. 1983. 
WISLER, G.C.; ZETTLER, F.W.; SHEEHAN, T.J. Common questions and misconceptions conceming orchid viruses. American Orchid Society Bulletin, v.55, n. 5 , p.472-479, May 1986.

WONG, S.M.; CHNG, C.G.; LEE, Y.H.; TAN, K.; ZETTLER, F.W. Incidence of cymbidium mosaic and odontoglossum ringspot viruses and their significance in orchid cultivation in Singapore. Crop Protection, v.13, n.3, p.235-239, 1994.

YUEN, C.K.K.H.; KAMEMOTO, H.; ISHII, M. Transmission of Cymbidium mosaic virus through seed propagation in Dendrobium. American Orchid Society Bulletin, v.48, n.12, p.1245-1247, Dec. 1979.

ZETTLER, F.W.; WISLER, G.C.; ELLIOTT, M.S.; KO, N.J. Some new, potencially significant viruses of orchids and their probable means of transmission. American Orchid Society Bulletin, v.56, n.10, p.1044-1051, Oct. 1987.

ZETTLER, F.W.; HENNEN, G.R.; BODNARUK JR., W.H.; CLIFFORD, H.T.; SHEEHAN, T.J. Wild and cultivated orchids surveyed in Florida for the Cymbidium mosaic and Odontoglossum ringspot viruses. Plant Disease Reporter, v.62, n.11, p.949-952, Nov. 1978.

ZETTLER, F.W.; KO, N.J.; WISLER, G.C.; ELLIOTT, M.; WONG, S.M. Viruses of orchids and their control. Plant Disease, v.74, n.9, p.621-626, 1990. 
APÊNDICE 1. Incidência de vírus em plantas provenientes de orquidários particulares do Estado de São Paulo 


\begin{tabular}{|c|c|c|c|c|c|c|c|}
\hline \multirow[t]{2}{*}{ Amostra } & \multirow[t]{2}{*}{ Procedência } & \multicolumn{6}{|c|}{ Número de amostras positivas/amostras testadas } \\
\hline & & ORSV & CyMV & ORSV+CyMV & CMV & CyRSV & DsMV \\
\hline Acacallis sp. & Atibaia & - & $0 / 2$ & - & $0 / 2$ & $0 / 2$ & $0 / 2$ \\
\hline Ansellia africana & Jundiaí & $0 / 1$ & $1 / 1$ & $0 / 1$ & $0 / 1$ & $0 / 1$ & $0 / 1$ \\
\hline \multicolumn{8}{|l|}{ Ascocenda $*$ V. Numancia $\mathrm{x}$} \\
\hline A. Meda Amold Figueiredo & Várzea Paulista & $0 / 1$ & $0 / 1$ & $0 / 1$ & $0 / 1$ & $0 / 1$ & $0 / 1$ \\
\hline \multicolumn{8}{|l|}{ Ascocentrum 'Peggy Foo' $\mathrm{x}$} \\
\hline A. curvifolium & Jundiaí & $0 / 3$ & $0 / 3$ & $0 / 3$ & $0 / 3$ & $0 / 3$ & $0 / 3$ \\
\hline Ascodoritis * Thay Cherry & Várzea Paulista & $0 / 1$ & $0 / 1$ & $0 / 1$ & $0 / 1$ & $0 / 1$ & $0 / 1$ \\
\hline Bifrenaria harrisoniae & Jundiaí & $0 / 1$ & $0 / 1$ & $0 / 1$ & $0 / 1$ & $0 / 1$ & $0 / 1$ \\
\hline$"$ & Pindamonhangaba & $0 / 1$ & $0 / 1$ & $0 / 1$ & $0 / 1$ & $0 / 1$ & $0 / 1$ \\
\hline B. tetragona & $"$ & $0 / 1$ & $0 / 1$ & $0 / 1$ & $0 / 1$ & $0 / 1$ & $0 / 1$ \\
\hline Brassavola tuberculata & Jundiaí & $0 / 2$ & $0 / 2$ & $0 / 2$ & $0 / 2$ & $0 / 2$ & $0 / 2$ \\
\hline Brassia longissima & Botucatu & $0 / 1$ & $0 / 1$ & $0 / 1$ & $0 / 1$ & $0 / 1$ & $0 / 1$ \\
\hline Brassocattleya $*$ Pastoral & Jundiaí & $0 / 1$ & $0 / 1$ & $0 / 1$ & $0 / 1$ & $0 / 1$ & $0 / 1$ \\
\hline Brassolaeliocattleya * 'Richard Muller' & $"$ & $0 / 1$ & $0 / 1$ & $0 / 1$ & $0 / 1$ & $0 / 1$ & $0 / 1$ \\
\hline Blc. Jane Helton 'Lanes' & Guararema & $0 / 1$ & $1 / 1$ & $0 / 1$ & $0 / 1$ & $0 / 1$ & $0 / 1$ \\
\hline Blc. Tiffin Bell's & $"$ & $0 / 1$ & $0 / 1$ & $0 / 1$ & $0 / 1$ & $0 / 1$ & $0 / 1$ \\
\hline Blc. Roberto Cardoso 'Florália' & São Paulo & $0 / 1$ & $0 / 1$ & $1 / 1$ & $0 / 1$ & $0 / 1$ & $0 / 1$ \\
\hline Bulbophyllum lobbii & Americana & $0 / 1$ & $0 / 1$ & $0 / 1$ & $0 / 1$ & $0 / 1$ & $0 / 1$ \\
\hline$"$ & Jundiaí & $0 / 1$ & $0 / 1$ & $0 / 1$ & $0 / 1$ & $0 / 1$ & $0 / 1$ \\
\hline Catasetum araguaiensis & $"$ & $0 / 1$ & $0 / 1$ & $0 / 1$ & $0 / 1$ & $0 / 1$ & $0 / 1$ \\
\hline C. fimbriatum & $"$ & $0 / 1$ & $0 / 1$ & $0 / 1$ & $0 / 1$ & $0 / 1$ & $0 / 1$ \\
\hline$"$ & Várzea Paulista & $0 / 1$ & $0 / 1$ & $0 / 1$ & $0 / 1$ & $0 / 1$ & $0 / 1$ \\
\hline C. spitzei & Jundiaí & $0 / 2$ & $0 / 2$ & $0 / 2$ & $0 / 2$ & $0 / 2$ & $0 / 2$ \\
\hline Catasetum sp. & $"$ & $0 / 1$ & $0 / 1$ & $0 / 1$ & $0 / 1$ & $0 / 1$ & $0 / 1$ \\
\hline Cattleya aclandiae & $"$ & $0 / 1$ & $0 / 1$ & $0 / 1$ & $0 / 1$ & $0 / 1$ & $0 / 1$ \\
\hline C. amethystoglossa & Campinas & $1 / 1$ & $0 / 1$ & $0 / 1$ & $0 / 1$ & $0 / 1$ & $0 / 1$ \\
\hline$"$ & Pindamonhangaba & $0 / 1$ & $1 / 1$ & $0 / 1$ & $0 / 1$ & $0 / 1$ & $0 / 1$ \\
\hline
\end{tabular}

* Gêneros que não ocorrem naturalmente 


\begin{tabular}{|c|c|c|c|c|c|c|c|}
\hline \multirow[t]{2}{*}{ Amostra } & \multirow[t]{2}{*}{ Procedência } & \multicolumn{6}{|c|}{ Número de amostras positivas/amostras testadas } \\
\hline & & ORSV & CyMV & ORSV+CyMV & CMV & CyRSV| & DsMV \\
\hline C. amethystoglossa x C. aclandiae & Jundiaí & $0 / 1$ & $0 / 1$ & $0 / 1$ & $0 / 1$ & $0 / 1$ & $0 / 1$ \\
\hline C. aurantiaca & $"$ & $0 / 1$ & $1 / 1$ & $0 / 1$ & $0 / 1$ & $0 / 1$ & $0 / 1$ \\
\hline$"$ & Santa Isabel & $0 / 1$ & $0 / 1$ & $0 / 1$ & $0 / 1$ & $0 / 1$ & $0 / 1$ \\
\hline C. Culminant & Várzea Paulista & $0 / 1$ & $0 / 1$ & $1 / 1$ & $0 / 1$ & $0 / 1$ & $0 / 1$ \\
\hline C. dormaniana & Campinas & $0 / 1$ & $0 / 1$ & $0 / 1$ & $0 / 1$ & $0 / 1$ & $0 / 1$ \\
\hline \multicolumn{8}{|l|}{ C. Enid Butterfly $\mathrm{x}$} \\
\hline C. Iuedemanniana 'Stanley'| & Jundiaí & $0 / 2$ & $0 / 2$ & $0 / 2$ & $0 / 2$ & $0 / 2$ & $0 / 2$ \\
\hline C. gigas & Várzea Paulista & $0 / 1$ & $1 / 1$ & $0 / 1$ & $0 / 1$ & $0 / 1$ & $0 / 1$ \\
\hline C. gigas 'tipo' & Botucatu & $0 / 1$ & $1 / 1$ & $0 / 1$ & $0 / 1$ & $0 / 1$ & $0 / 1$ \\
\hline C. Intertexta & $"$ & $0 / 1$ & $0 / 1$ & $0 / 1$ & $0 / 1$ & $0 / 1$ & $0 / 1$ \\
\hline C. João Antonio Nicole & Jundiaí & $0 / 1$ & $1 / 1$ & $0 / 1$ & $0 / 1$ & $0 / 1$ & $0 / 1$ \\
\hline C. labiata & S.B. Campo & $0 / 2$ & $0 / 2$ & $0 / 2$ & $0 / 2$ & $0 / 2$ & $0 / 2$ \\
\hline$"$ & Várzea Paulista & $0 / 1$ & $0 / 1$ & $0 / 1$ & $0 / 1$ & $0 / 1$ & $0 / 1$ \\
\hline C. loddigesii & Atibaia & $0 / 7$ & $3 / 10$ & $0 / 7$ & $0 / 10$ & $0 / 10$ & $0 / 10$ \\
\hline C. loddigesii 'tipo' & Várzea Paulista & $0 / 3$ & $0 / 3$ & $0 / 3$ & $0 / 3$ & $0 / 3$ & $0 / 3$ \\
\hline C. loddigesii 'pérola' & Jundiaí & $0 / 1$ & $1 / 1$ & $0 / 1$ & $0 / 1$ & $0 / 1$ & $0 / 1$ \\
\hline C. loddigesii x C. forbesii & Botucatu & $0 / 1$ & $1 / 1$ & $0 / 1$ & $0 / 1$ & $0 / 1$ & $0 / 1$ \\
\hline C. nobilior & Jundiaí & $0 / 2$ & $0 / 2$ & $0 / 2$ & $0 / 2$ & $0 / 2$ & $0 / 2$ \\
\hline C. Portia 'coerulea' & $"$ & $0 / 1$ & $1 / 1$ & $0 / 1$ & $0 / 1$ & $0 / 1$ & $0 / 1$ \\
\hline C. Portia 'gloriosa' & $"$ & $0 / 1$ & $0 / 1$ & $0 / 1$ & $0 / 1$ & $0 / 1$ & $0 / 1$ \\
\hline C. Portia 'gloriosa extra' & $"$ & $0 / 1$ & $1 / 1$ & $0 / 1$ & $0 / 1$ & $0 / 1$ & $0 / 1$ \\
\hline \multicolumn{8}{|l|}{ C. Penny Kuroda 'spots' $\mathrm{x}$} \\
\hline C. Edgard van Belle & $"$ & $0 / 1$ & $0 / 1$ & $0 / 1$ & $0 / 1$ & $0 / 1$ & $0 / 1$ \\
\hline Cattleya Sheila & $"$ & $1 / 1$ & $0 / 1$ & $0 / 1$ & $0 / 1$ & $0 / 1$ & $0 / 1$ \\
\hline Cattleya semi alba & $"$ & $0 / 1$ & $1 / 1$ & $0 / 1$ & $0 / 1$ & $0 / 1$ & $0 / 1$ \\
\hline C. skinnerii & $"$ & $0 / 1$ & $0 / 1$ & $0 / 1$ & $0 / 1$ & $0 / 1$ & $0 / 1$ \\
\hline C. Sonia Altenburg & São Paulo & $0 / 1$ & $0 / 1$ & $1 / 1$ & $0 / 1$ & $0 / 1$ & $0 / 1$ \\
\hline
\end{tabular}




\begin{tabular}{|c|c|c|c|c|c|c|c|}
\hline \multirow[t]{2}{*}{ Amostra } & \multirow[t]{2}{*}{ Procedência } & \multicolumn{6}{|c|}{ Número de amostras positivas/amostras testadas } \\
\hline & & ORSV & CyMV & ORSV+CyMV & CMV & CyRSV & DsMV \\
\hline C. trianaei var. amesiana & Jundiaí & $0 / 1$ & $0 / 1$ & $0 / 1$ & $0 / 1$ & $0 / 1$ & $0 / 1$ \\
\hline C. Valentine $\mathrm{x}$ C. mendelli 'coerulea' & $"$ & $0 / 2$ & $0 / 2$ & $0 / 2$ & $0 / 2$ & $0 / 2$ & $0 / 2$ \\
\hline C. warnerii & $"$ & $0 / 1$ & $0 / 1$ & $0 / 1$ & $0 / 1$ & $0 / 1$ & $0 / 1$ \\
\hline$"$ & Pindamonhangaba & $0 / 1$ & $0 / 1$ & $0 / 1$ & $0 / 1$ & $0 / 1$ & $0 / 1$ \\
\hline Cattleya hibrida & Americana & $0 / 2$ & $0 / 2$ & $1 / 2$ & $0 / 2$ & $0 / 2$ & $0 / 2$ \\
\hline$"$ & Atibaia & $1 / 6$ & $6 / 7$ & $0 / 6$ & $0 / 7$ & $0 / 7$ & $0 / 7$ \\
\hline$"$ & Botucatu & $0 / 1$ & $1 / 1$ & $0 / 1$ & - & - & - \\
\hline$"$ & Campinas & $0 / 3$ & $7 / 12$ & $0 / 3$ & $0 / 12$ & $0 / 1$ & $0 / 1$ \\
\hline$"$ & Carapicuíba & $1 / 1$ & $0 / 1$ & $0 / 1$ & - & - & - \\
\hline$"$ & Jundiaí & $4 / 16$ & $1 / 16$ & $0 / 16$ & $0 / 16$ & $0 / 16$ & $0 / 16$ \\
\hline$"$ & Peruíbe & $0 / 3$ & $0 / 3$ & $1 / 3$ & $0 / 3$ & $0 / 3$ & $0 / 3$ \\
\hline$"$ & Piracicaba & $0 / 3$ & $2 / 3$ & $0 / 3$ & - & - & - \\
\hline$"$ & S. B. Campo & $0 / 10$ & $2 / 10$ & $7 / 10$ & $0 / 10$ & $0 / 10$ & $0 / 10$ \\
\hline$"$ & São Paulo & $0 / 1$ & $1 / 4$ & $0 / 1$ & $0 / 4$ & $0 / 4$ & $0 / 4$ \\
\hline$"$ & Várzea Paulista & $0 / 1$ & $1 / 1$ & $0 / 1$ & $0 / 1$ & $0 / 1$ & $0 / 1$ \\
\hline Cochleantes sp. & Piracicaba & $0 / 1$ & $0 / 1$ & $0 / 1$ & $0 / 1$ & $0 / 1$ & $0 / 1$ \\
\hline Coelogvne var. alba & Jundiaí & $0 / 1$ & $0 / 1$ & $0 / 1$ & $0 / 1$ & $0 / 1$ & $0 / 1$ \\
\hline C. flaccida & Botucatu & $0 / 1$ & $0 / 1$ & $0 / 1$ & $0 / 1$ & $0 / 1$ & $0 / 1$ \\
\hline$"$ & Jundiaí & $0 / 3$ & $0 / 3$ & $0 / 3$ & $0 / 3$ & $0 / 3$ & $0 / 3$ \\
\hline C. lactea & Pindamonhangaba & $0 / 1$ & $0 / 1$ & $0 / 1$ & $0 / 1$ & $0 / 1$ & $0 / 1$ \\
\hline C. massangeana & Jundiaí & $0 / 1$ & $0 / 1$ & $0 / 1$ & $0 / 1$ & $0 / 1$ & $0 / 1$ \\
\hline Coelogune sp. & Atibaia & $0 / 1$ & $1 / 1$ & $0 / 1$ & $0 / 1$ & $0 / 1$ & $0 / 1$ \\
\hline$"$ & Campinas & $0 / 2$ & $0 / 2$ & $0 / 2$ & $0 / 2$ & $0 / 2$ & $0 / 2$ \\
\hline \multicolumn{8}{|l|}{ Cymbidium var. Ayako Tanaka } \\
\hline Hinodezuru' & Atibaia & $30 / 30$ & $0 / 30$ & $0 / 30$ & - & $0 / 30$ & - \\
\hline var. Valentine's Love 'The King' & $"$ & $6 / 18$ & $0 / 22$ & $0 / 18$ & $0 / 18$ & $0 / 13$ & $0 / 13$ \\
\hline var. Xtmas. Clarete & $"$ & $1 / 1$ & $0 / 1$ & $0 / 1$ & - & - & - \\
\hline
\end{tabular}




\begin{tabular}{|c|c|c|c|c|c|c|c|}
\hline \multirow[t]{2}{*}{ Amostra } & \multirow[t]{2}{*}{ Procedência } & \multicolumn{6}{|c|}{ Número de amostras positivas/amostras testadas } \\
\hline & & ORSV & CyMV & ORSV+CyMV & CMV & CyRSV & DsMV \\
\hline Cymbidium híbrido & Atibaia & $49 / 845$ & $0 / 856$ & $2 / 845$ & $0 / 163$ & $0 / 163$ & $0 / 163$ \\
\hline$"$ & Jundiaí & $2 / 2$ & $0 / 2$ & $0 / 2$ & $0 / 2$ & $0 / 2$ & $0 / 2$ \\
\hline$"$ & São Paulo & $0 / 1$ & $1 / 1$ & $0 / 1$ & $0 / 1$ & $0 / 1$ & $0 / 1$ \\
\hline Dendrobium aggregatum & Jundiaí & $0 / 1$ & $0 / 1$ & $0 / 1$ & $0 / 1$ & $0 / 1$ & $0 / 1$ \\
\hline D. amethystoglossum & $"$ & $0 / 2$ & $0 / 2$ & $0 / 2$ & $0 / 2$ & $0 / 2$ & $0 / 2$ \\
\hline D. chrysotoxum & $"$ & $0 / 3$ & $3 / 3$ & $0 / 3$ & $0 / 3$ & $0 / 3$ & $0 / 3$ \\
\hline D. kingyanum & Pindamonhangaba & $0 / 1$ & $0 / 1$ & $0 / 1$ & $0 / 1$ & $0 / 1$ & $0 / 1$ \\
\hline D. Madame Chuli & Várzea Paulista & $0 / 2$ & $2 / 2$ & $0 / 2$ & $0 / 2$ & $0 / 2$ & $0 / 2$ \\
\hline D. Mousmee $\times$ D. thyrsiflorum & Botucatu & $0 / 1$ & $0 / 1$ & $0 / 1$ & $0 / 1$ & $0 / 1$ & $0 / 1$ \\
\hline D. nobile híbrido & Atibaia & $0 / 4$ & $1 / 4$ & $0 / 4$ & $0 / 4$ & $0 / 4$ & $0 / 4$ \\
\hline$"$ & Campinas & $0 / 7$ & $0 / 7$ & $0 / 7$ & $0 / 7$ & $0 / 7$ & $0 / 7$ \\
\hline$"$ & Jundiaí & $0 / 4$ & $0 / 4$ & $0 / 4$ & $0 / 4$ & $0 / 4$ & $0 / 4$ \\
\hline$"$ & São Paulo & $0 / 8$ & $0 / 12$ & $0 / 8$ & $0 / 12$ & $0 / 12$ & $0 / 12$ \\
\hline D. Pixie Princess & Várzea Paulista & $0 / 3$ & $3 / 3$ & $0 / 3$ & $0 / 3$ & $0 / 3$ & $0 / 3$ \\
\hline D. speciosum var. alba & Jundiaí & $0 / 3$ & $0 / 3$ & $0 / 3$ & $0 / 3$ & $0 / 3$ & $0 / 3$ \\
\hline$D$. Thay Pixie & Várzea Paulista & $0 / 2$ & $0 / 2$ & $0 / 2$ & $0 / 2$ & $0 / 2$ & $0 / 2$ \\
\hline D. thyrsiflorum & Jundiaí & $0 / 3$ & $2 / 3$ & $0 / 3$ & $0 / 3$ & $0 / 3$ & $0 / 3$ \\
\hline D. Pink Sem 'Sabine' (Denphale) & Várzea Paulista & $0 / 1$ & $1 / 1$ & $0 / 1$ & $0 / 1$ & $0 / 1$ & $0 / 1$ \\
\hline D. Yoko (Denphale) & $"$ & $0 / 1$ & $1 / 1$ & $0 / 1$ & $0 / 1$ & $0 / 1$ & $0 / 1$ \\
\hline D. phalaenopsis híbrido & Atibaia & $0 / 4$ & $0 / 4$ & $0 / 4$ & $0 / 4$ & $0 / 4$ & $0 / 4$ \\
\hline Dendrochillum latifolium & Jundiaí & $0 / 1$ & $0 / 1$ & $0 / 1$ & $0 / 1$ & $0 / 1$ & $0 / 1$ \\
\hline Dendrochillum híbrido & Várzea Paulista & $0 / 1$ & $1 / 1$ & $0 / 1$ & $0 / 1$ & $0 / 1$ & $0 / 1$ \\
\hline Encyclia oncidioides & Pindamonhangaba & $0 / 1$ & $0 / 1$ & $0 / 1$ & $0 / 1$ & $0 / 1$ & $0 / 1$ \\
\hline E. patens & Jundiaí & $0 / 3$ & $0 / 3$ & $0 / 3$ & $0 / 3$ & $0 / 3$ & $0 / 3$ \\
\hline E. vespa & Pindamonhangaba & $0 / 1$ & $0 / 1$ & $0 / 1$ & $0 / 1$ & $0 / 1$ & $0 / 1$ \\
\hline Epidendrum allemanoides & Botucatu & $0 / 1$ & $0 / 1$ & $0 / 1$ & $0 / 1$ & $0 / 1$ & $0 / 1$ \\
\hline E. pentotes & Jundiaí & $0 / 1$ & $0 / 1$ & $0 / 1$ & $0 / 1$ & $0 / 1$ & $0 / 1$ \\
\hline
\end{tabular}




\begin{tabular}{|c|c|c|c|c|c|c|c|}
\hline \multirow[t]{2}{*}{ Amostra } & \multirow[t]{2}{*}{ Procedência } & \multicolumn{6}{|c|}{ Número de amostras positivas/amostras testadas } \\
\hline & & ORSV & CyMV & ORSV+CyMV & CMV & CyRSV & DsMV \\
\hline Epidendrum sp. & Jundiaí & $1 / 2$ & $0 / 2$ & $0 / 2$ & $0 / 2$ & $0 / 2$ & $0 / 2$ \\
\hline$"$ & Valinhos & $0 / 1$ & $0 / 1$ & $0 / 1$ & - & - & - \\
\hline Eria sp. & Várzea Paulista & $0 / 1$ & $0 / 1$ & $0 / 1$ & $0 / 1$ & $0 / 1$ & $0 / 1$ \\
\hline Galeandra sp. & Jundiaí & $0 / 1$ & $0 / 1$ & $0 / 1$ & $0 / 1$ & $0 / 1$ & $0 / 1$ \\
\hline$"$ & Várzea Paulista & $0 / 1$ & $0 / 1$ & $0 / 1$ & $0 / 1$ & $0 / 1$ & $0 / 1$ \\
\hline Gomesa sp. & Piracicaba & $0 / 1$ & $0 / 1$ & $0 / 1$ & $0 / 1$ & $0 / 1$ & $0 / 1$ \\
\hline Gongora quinquenervis & Americana & $0 / 1$ & $0 / 1$ & $0 / 1$ & $0 / 1$ & $0 / 1$ & $0 / 1$ \\
\hline Habernaria sp. & Piracicaba & $0 / 1$ & $0 / 1$ & $0 / 1$ & $0 / 1$ & $0 / 1$ & $0 / 1$ \\
\hline Koellensteinia sp. & Jundiaí & $0 / 1$ & $0 / 1$ & $0 / 1$ & $0 / 1$ & $0 / 1$ & $0 / 1$ \\
\hline Laelia alaorii & Campinas & $0 / 1$ & $0 / 1$ & $0 / 1$ & $0 / 1$ & $0 / 1$ & $0 / 1$ \\
\hline L. cinnabarina & Jundiaí & $0 / 2$ & $0 / 2$ & $0 / 2$ & $0 / 2$ & $0 / 2$ & $0 / 2$ \\
\hline L. crispa & Pindamonhangaba & $0 / 1$ & $0 / 1$ & $0 / 1$ & $0 / 1$ & $0 / 1$ & $0 / 1$ \\
\hline L. crispa var. camea & Botucatu & $0 / 1$ & $0 / 1$ & $1 / 1$ & $0 / 1$ & $0 / 1$ & $0 / 1$ \\
\hline L. jongheana & Jundiaí & $0 / 1$ & $0 / 1$ & $0 / 1$ & $0 / 1$ & $0 / 1$ & $0 / 1$ \\
\hline L. perrinii & Campinas & $0 / 1$ & $0 / 1$ & $0 / 1$ & $0 / 1$ & $0 / 1$ & $0 / 1$ \\
\hline$"$ & Pindamonhangaba & $0 / 1$ & $0 / 1$ & $0 / 1$ & $0 / 1$ & $0 / 1$ & $0 / 1$ \\
\hline L. purpurata & Botucatu & $0 / 1$ & $0 / 1$ & $0 / 1$ & $0 / 1$ & $0 / 1$ & $0 / 1$ \\
\hline$"$ & Pindamonhangaba & $0 / 1$ & $0 / 1$ & $0 / 1$ & $0 / 1$ & $0 / 1$ & $0 / 1$ \\
\hline$"$ & S. B. Campo & $0 / 2$ & $1 / 2$ & $0 / 2$ & $0 / 2$ & $0 / 2$ & $0 / 2$ \\
\hline L.purpurata var.argolão & Botucatu & $0 / 1$ & $0 / 1$ & $1 / 1$ & $0 / 1$ & $0 / 1$ & $0 / 1$ \\
\hline L purpurata var. camea & Jundiaí & $0 / 3$ & $0 / 3$ & $0 / 3$ & $0 / 3$ & $0 / 3$ & $0 / 3$ \\
\hline L.purpurata var. anelata $\times$ oculata & Botucatu & $0 / 1$ & $0 / 1$ & $0 / 1$ & $0 / 1$ & $0 / 1$ & $0 / 1$ \\
\hline L.purpurata var. estriata & $"$ & $1 / 1$ & $0 / 1$ & $0 / 1$ & $0 / 1$ & $0 / 1$ & $0 / 1$ \\
\hline L. tenebrosa & Jundiaí & $0 / 1$ & $1 / 1$ & $0 / 1$ & $0 / 1$ & $0 / 1$ & $0 / 1$ \\
\hline Laelia sp. & Campinas & $0 / 2$ & $0 / 2$ & $0 / 2$ & $0 / 2$ & $0 / 2$ & $0 / 2$ \\
\hline$"$ & Pindamonhangaba & $0 / 1$ & $0 / 1$ & $0 / 1$ & $0 / 1$ & $0 / 1$ & $0 / 1$ \\
\hline
\end{tabular}




\begin{tabular}{|c|c|c|c|c|c|c|c|}
\hline \multirow[t]{2}{*}{ Amostra } & \multirow[t]{2}{*}{ Procedência } & \multicolumn{6}{|c|}{ Número de amostras positivas/amostras testadas } \\
\hline & & ORSV & CyMV & ORSV+CyMV & CMV & CyRSV & DsMV \\
\hline \multicolumn{8}{|l|}{ Laeliocattleya $*$ California Beauty $\mathrm{x}$} \\
\hline Lc. Dorothy Fried & Jundiaí & $0 / 1$ & $1 / 1$ & $0 / 1$ & $0 / 1$ & $0 / 1$ & $0 / 1$ \\
\hline \multicolumn{8}{|l|}{ Lc. Alfredo Martinelli x Lc. } \\
\hline Drumbeat 'San Gabriel' & $"$ & $0 / 2$ & $1 / 2$ & $1 / 2$ & $0 / 2$ & $0 / 2$ & $0 / 2$ \\
\hline \multicolumn{8}{|l|}{ Lc. Washington Luiz $\mathrm{x}$} \\
\hline Lc. Culminant 'La Tuliere'| & $"$ & $1 / 1$ & $0 / 1$ & $0 / 1$ & $0 / 1$ & $0 / 1$ & $0 / 1$ \\
\hline Lc. Mini purpule & S. B. Campo & $0 / 1$ & $0 / 1$ & $0 / 1$ & $0 / 1$ & $0 / 1$ & $0 / 1$ \\
\hline Lc. Amber Glow & $"$ & $1 / 1$ & $0 / 1$ & $0 / 1$ & $0 / 1$ & $0 / 1$ & $0 / 1$ \\
\hline Miltonia Asa Branca & Várzea Paulista & $0 / 1$ & $0 / 1$ & $0 / 1$ & $0 / 1$ & $0 / 1$ & $0 / 1$ \\
\hline M. cuneata & $"$ & $0 / 1$ & $0 / 1$ & $0 / 1$ & $0 / 1$ & $0 / 1$ & $0 / 1$ \\
\hline M. Pan Pan & $"$ & $0 / 1$ & $0 / 1$ & $0 / 1$ & $0 / 1$ & $0 / 1$ & $0 / 1$ \\
\hline$"$ & São Paulo & $0 / 1$ & $0 / 1$ & $0 / 1$ & $0 / 1$ & $0 / 1$ & $0 / 1$ \\
\hline Miltonia sp. & Atibaia & $0 / 1$ & $0 / 2$ & $0 / 1$ & $0 / 1$ & $0 / 1$ & $0 / 1$ \\
\hline Oeceoclades maculata & Piracicaba & $0 / 5$ & $0 / 5$ & $0 / 5$ & $0 / 5$ & $0 / 5$ & $0 / 5$ \\
\hline Oncidium crispum & Jundiaí & $0 / 1$ & $0 / 1$ & $0 / 1$ & $0 / 1$ & $0 / 1$ & $0 / 1$ \\
\hline O. flexuosum & $"$ & $0 / 1$ & $0 / 1$ & $0 / 1$ & $0 / 1$ & $0 / 1$ & $0 / 1$ \\
\hline O. jonesianum & $"$ & $0 / 1$ & $0 / 1$ & $0 / 1$ & $0 / 1$ & $0 / 1$ & $0 / 1$ \\
\hline O. longissimum & Americana & $0 / 1$ & $0 / 1$ & $0 / 1$ & $0 / 1$ & $0 / 1$ & $0 / 1$ \\
\hline O. pubes & Jundiaí & $0 / 1$ & $0 / 1$ & $0 / 1$ & $0 / 1$ & $0 / 1$ & $0 / 1$ \\
\hline O. varicosum & $"$ & $0 / 2$ & $0 / 2$ & $0 / 2$ & $0 / 2$ & $0 / 2$ & $0 / 2$ \\
\hline$"$ & Várzea Paulista & $0 / 1$ & $0 / 1$ & $0 / 1$ & $0 / 1$ & $0 / 1$ & $0 / 1$ \\
\hline Oncidium sp. & Atibaia & $0 / 27$ & $12 / 27$ & $0 / 27$ & $0 / 27$ & $0 / 27$ & $0 / 27$ \\
\hline$"$ & São Paulo & $0 / 1$ & $0 / 1$ & $0 / 1$ & $0 / 1$ & $0 / 1$ & $0 / 1$ \\
\hline Paphiopedilum híbrido & S. B. Campo & $0 / 1$ & $0 / 1$ & $0 / 1$ & $0 / 1$ & $0 / 1$ & $0 / 1$ \\
\hline \multicolumn{8}{|l|}{ Phalaenopsis Gigantea Chunching } \\
\hline $\mathrm{x} P$. Hing Cheng & Jundiaí & $0 / 2$ & $0 / 2$ & $0 / 2$ & $0 / 2$ & $0 / 2$ & $0 / 2$ \\
\hline Phalaenopsis híbrido & Atibaia & $6 / 168$ & $29 / 167$ & $30 / 166$ & $0 / 96$ & $0 / 96$ & $0 / 96$ \\
\hline
\end{tabular}

* Gêneros que não ocorrem naturalmente 


\begin{tabular}{|c|c|c|c|c|c|c|c|}
\hline \multirow[t]{2}{*}{ Amostra } & \multirow[t]{2}{*}{ Procedência } & \multicolumn{6}{|c|}{ Número de amostras positivas/amostras testadas } \\
\hline & & ORSV & CyMV & ORSV+CyMV| & CMV & CyRSV| & DsMV \\
\hline Phalaenopsis híbrido & Jundiaí & $0 / 8$ & $4 / 8$ & $4 / 8$ & $0 / 8$ & $0 / 8$ & $0 / 8$ \\
\hline$"$ & S. J. Campos & $0 / 1$ & $0 / 1$ & $0 / 1$ & $0 / 1$ & $0 / 1$ & $0 / 1$ \\
\hline Pleurothallis sp. & Jundiaí & $0 / 1$ & $0 / 1$ & $0 / 1$ & $0 / 1$ & $0 / 1$ & $0 / 1$ \\
\hline Psychopsis papilio & $"$ & $0 / 1$ & $1 / 1$ & $0 / 1$ & $0 / 1$ & $0 / 1$ & $0 / 1$ \\
\hline Renanthera coccinea & Várzea Paulista & $0 / 2$ & $0 / 2$ & $0 / 2$ & $0 / 2$ & $0 / 2$ & $0 / 2$ \\
\hline Rhyncholaelia* digbyana & Jundiaí & $0 / 1$ & $0 / 1$ & $0 / 1$ & $0 / 1$ & $0 / 1$ & $0 / 1$ \\
\hline Rhynchostilis gigantea & $"$ & $0 / 1$ & $0 / 1$ & $0 / 1$ & $0 / 1$ & $0 / 1$ & $0 / 1$ \\
\hline Rodriguezia bracteata & $"$ & $0 / 2$ & $0 / 2$ & $0 / 2$ & $0 / 2$ & $0 / 2$ & $0 / 2$ \\
\hline$R$. decora & $"$ & $0 / 2$ & $0 / 2$ & $0 / 2$ & $0 / 2$ & $0 / 2$ & $0 / 2$ \\
\hline Sigmatostalix radicans & $"$ & $0 / 2$ & $0 / 2$ & $0 / 2$ & $0 / 2$ & $0 / 2$ & $0 / 2$ \\
\hline Sophrolaeliocattleya * A182 & & & & & & & \\
\hline Falcon Alexanderi & $"$ & $0 / 1$ & $1 / 1$ & $0 / 1$ & $0 / 1$ & $0 / 1$ & $0 / 1$ \\
\hline Slc. Jewell box & $"$ & $0 / 3$ & $0 / 3$ & $0 / 3$ & $0 / 3$ & $0 / 3$ & $0 / 3$ \\
\hline Slc. Mac Hawkins & São Paulo & $0 / 1$ & $0 / 1$ & $0 / 1$ & $0 / 1$ & $0 / 1$ & $0 / 1$ \\
\hline Slc. híbrido & Campinas & $0 / 1$ & $0 / 1$ & $0 / 1$ & $0 / 1$ & $0 / 1$ & $0 / 1$ \\
\hline Sophronitis coccinea & Jundiaí & $0 / 2$ & $0 / 2$ & $0 / 2$ & $0 / 2$ & $0 / 2$ & $0 / 2$ \\
\hline Stanhopea grandiflora & Várzea Paulista & $0 / 1$ & $0 / 1$ & $0 / 1$ & $0 / 1$ & $0 / 1$ & $0 / 1$ \\
\hline S. wardii & Botucatu & $0 / 1$ & $0 / 1$ & $0 / 1$ & $0 / 1$ & $0 / 1$ & $0 / 1$ \\
\hline Vanda coerulea & Jundiaí & $0 / 1$ & $0 / 1$ & $0 / 1$ & $0 / 1$ & $0 / 1$ & $0 / 1$ \\
\hline$V$. Madame Rattana & Várzea Paulista & $0 / 1$ & $0 / 1$ & $0 / 1$ & $0 / 1$ & $0 / 1$ & $0 / 1$ \\
\hline$V$. Thanchay $\mathrm{x} V$. Sepray & Jundiaí & $0 / 1$ & $0 / 1$ & $0 / 1$ & $0 / 1$ & $0 / 1$ & $0 / 1$ \\
\hline Vanda $\mathrm{sp}$. & $"$ & $0 / 1$ & $0 / 1$ & $0 / 1$ & $0 / 1$ & $0 / 1$ & $0 / 1$ \\
\hline Vanilla bidentata & Várzea Paulista & $0 / 1$ & $0 / 1$ & $0 / 1$ & $0 / 1$ & $0 / 1$ & $0 / 1$ \\
\hline Xylobium squalens & Botucatu & $0 / 1$ & $0 / 1$ & $0 / 1$ & $0 / 1$ & $0 / 1$ & $0 / 1$ \\
\hline Zygopetalum mackoyi & Jundiaí & $0 / 2$ & $0 / 2$ & $0 / 2$ & $0 / 2$ & $0 / 2$ & $0 / 2$ \\
\hline 2. maxillare & $"$ & $0 / 1$ & $0 / 1$ & $0 / 1$ & $0 / 1$ & $0 / 1$ & $0 / 1$ \\
\hline
\end{tabular}

* Gêneros que não ocorrem naturalmente 


\begin{tabular}{|c|c|c|c|c|c|c|c|}
\hline Amostra & Procedência & Núı & mero de a & mostras positiva & /amost & as testad & \\
\hline & & ORSV & CyMV & ORSV+CyMV & CMV & CyRSV & DsMV \\
\hline Híbridos intergenéricos & & & & & & & \\
\hline Arachnis sp. $\mathrm{x}$ Renanthera sp. & Várzea Paulista & $0 / 1$ & $1 / 1$ & $0 / 1$ & $0 / 1$ & $0 / 1$ & $0 / 1$ \\
\hline Ascocenda * 'Peggy Foo' $\mathrm{x}$ & & & & & & & \\
\hline Vanda coerulea & Jundiaí & $0 / 1$ & $0 / 1$ & $0 / 1$ & $0 / 1$ & $0 / 1$ & $0 / 1$ \\
\hline Brassocattleya $*$ Amy Wakasuqui $\mathrm{x}$ & & & & & & & \\
\hline Laeliocattleya* Crispin Rosalles & $"$ & $0 / 3$ & $0 / 3$ & $0 / 3$ & $0 / 3$ & $0 / 3$ & $0 / 3$ \\
\hline Blc. ${ }^{*}$ Haley $\mathrm{x}$ Lc. ${ }^{*}$ Shine button D'or & $"$ & $0 / 1$ & $0 / 1$ & $0 / 1$ & $0 / 1$ & $0 / 1$ & $0 / 1$ \\
\hline Blc. Orchidglade $\mathrm{x}$ Cattleya & & & & & & & \\
\hline Peney Kuroda 'spots' & $"$ & $0 / 1$ & $0 / 1$ & $0 / 1$ & $0 / 1$ & $0 / 1$ & $0 / 1$ \\
\hline Blc. Turandot 'Araraquara' $\mathrm{x} L c$. & & & & & & & \\
\hline Drumbeat 'San Gabriel' & $"$ & $0 / 3$ & $1 / 3$ & $0 / 3$ & $0 / 3$ & $0 / 3$ & $0 / 3$ \\
\hline Cattleya bowringiana $\mathrm{x}$ & & & & & & & \\
\hline Lc. Diogo Nomura X C. J.D. Castro & $"$ & $0 / 3$ & $0 / 3$ & $0 / 3$ & $0 / 3$ & $0 / 3$ & $0 / 3$ \\
\hline Lc. Walter Slagle $\times B c$. Pastoral & $"$ & $1 / 4$ & $0 / 4$ & $0 / 4$ & $0 / 4$ & $0 / 4$ & $0 / 4$ \\
\hline Lc. Walter Slagle $\mathrm{x}$ Lc. Bonanza & & & & & & & \\
\hline territorial' $\mathrm{x} B C$. Pastoral alba & $"$ & $0 / 1$ & $0 / 1$ & $0 / 1$ & $0 / 1$ & $0 / 1$ & $0 / 1$ \\
\hline Oncidium crispum $\times$ B. verrucosa & $"$ & $0 / 2$ & $0 / 2$ & $0 / 2$ & $0 / 2$ & $0 / 2$ & $0 / 2$ \\
\hline Sophrocattleya $*$ Corsair salmon $\mathrm{x}$ & & & & & & & \\
\hline C. Anzae 'Orchidurst' & $"$ & $0 / 2$ & $0 / 2$ & $0 / 2$ & $0 / 2$ & $0 / 2$ & $0 / 2$ \\
\hline Vanda Keeree Sapphire $\mathrm{x}$ & & & & & & & \\
\hline Ascocenda Bigness & $"$ & $0 / 1$ & $0 / 1$ & $0 / 1$ & $0 / 1$ & $0 / 1$ & $0 / 1$ \\
\hline Orq. não identificadas & Atibaia & $0 / 2$ & $0 / 3$ & $0 / 2$ & $0 / 3$ & $0 / 3$ & $0 / 3$ \\
\hline$"$ & Campinas & $1 / 15$ & $3 / 15$ & $0 / 15$ & $0 / 15$ & $0 / 15$ & $0 / 15$ \\
\hline$"$ & Piracicaba & $0 / 1$ & $0 / 1$ & $0 / 1$ & $0 / 1$ & $0 / 1$ & $0 / 1$ \\
\hline$"$ & São Paulo & $0 / 1$ & $0 / 1$ & $0 / 1$ & - & - & - \\
\hline Total & & $108 / 1420$ & $108 / 1458$ & $51 / 1418$ & $0 / 651$ & $0 / 676$ & $0 / 646$ \\
\hline
\end{tabular}

* Gêneros que não ocorrem naturalmente 
APÊNDICE 2. Incidência de vírus em plantas provenientes do orquidário de coleção da ESALQ/USP 


\begin{tabular}{|c|c|c|c|c|c|c|}
\hline \multirow[t]{2}{*}{ Amostra } & \multirow[b]{2}{*}{ ORSV } & \multicolumn{4}{|c|}{ Número de amostras positivas/amostras testadas } & \multirow[b]{2}{*}{ DsMV } \\
\hline & & CyMV & ORSV+CyMV & CMV & CyRSV & \\
\hline Aspasia lunata & $0 / 1$ & $0 / 1$ & $0 / 1$ & $0 / 1$ & $0 / 1$ & $0 / 1$ \\
\hline Bifrenaria tetragona $\times$ B. aurea & $0 / 1$ & $0 / 1$ & $0 / 1$ & $0 / 1$ & $0 / 1$ & $0 / 1$ \\
\hline Brassia arachnoides & $0 / 3$ & $0 / 3$ & $0 / 3$ & $0 / 3$ & $0 / 3$ & $0 / 3$ \\
\hline B. chloroleuca & $0 / 6$ & $0 / 6$ & $0 / 6$ & $0 / 6$ & $0 / 6$ & $0 / 6$ \\
\hline B. thyrsoides boliviensi & $0 / 1$ & $0 / 1$ & $0 / 1$ & $0 / 1$ & $0 / 1$ & $0 / 1$ \\
\hline Bulbophyllum cauliflorum & $0 / 1$ & $0 / 1$ & $0 / 1$ & $0 / 1$ & $0 / 1$ & $0 / 1$ \\
\hline B. lobbii & $0 / 1$ & $0 / 1$ & $0 / 1$ & $0 / 1$ & $0 / 1$ & $0 / 1$ \\
\hline Bulbophyllum sp. & $0 / 4$ & $1 / 4$ & $1 / 4$ & $0 / 4$ & $0 / 4$ & $0 / 4$ \\
\hline Catasetum sp. & $0 / 1$ & $0 / 1$ & $0 / 1$ & $0 / 1$ & $0 / 1$ & $0 / 1$ \\
\hline Cattleya aurantiaca $x$ C. shoroderae & $0 / 1$ & $0 / 1$ & $0 / 1$ & $0 / 1$ & $0 / 1$ & $0 / 1$ \\
\hline C. bicolor & $0 / 1$ & $0 / 1$ & $0 / 1$ & $0 / 1$ & $0 / 1$ & $0 / 1$ \\
\hline C. bicolor x C. bicolor & $0 / 1$ & $1 / 1$ & $0 / 1$ & $0 / 1$ & $0 / 1$ & $0 / 1$ \\
\hline C. dormaniana $\times$ C. aurantiaca & $0 / 1$ & $0 / 1$ & $0 / 1$ & $0 / 1$ & $0 / 1$ & $0 / 1$ \\
\hline C. gaskelliana & $0 / 2$ & $0 / 2$ & $2 / 2$ & $0 / 2$ & $0 / 2$ & $0 / 2$ \\
\hline C. gaskelliana x labiata & $0 / 1$ & $0 / 1$ & $0 / 1$ & $0 / 1$ & $0 / 1$ & $0 / 1$ \\
\hline C. gigas & $0 / 1$ & $0 / 1$ & $0 / 1$ & $0 / 1$ & $0 / 1$ & $0 / 1$ \\
\hline C. gigas semi alba & $0 / 3$ & $0 / 3$ & $0 / 3$ & $0 / 3$ & $0 / 3$ & $0 / 3$ \\
\hline C. granulosa & $1 / 2$ & $0 / 2$ & $0 / 2$ & $0 / 2$ & $0 / 2$ & $0 / 2$ \\
\hline C. harrisoniana & $1 / 3$ & $0 / 5$ & $2 / 3$ & $0 / 5$ & $0 / 5$ & $0 / 5$ \\
\hline C. harrisoniana 'Extra' & $0 / 1$ & $1 / 1$ & $0 / 1$ & $0 / 1$ & $0 / 1$ & $0 / 1$ \\
\hline C.harrisoniana purpurea & $0 / 1$ & $1 / 1$ & $0 / 1$ & $0 / 1$ & $0 / 1$ & $0 / 1$ \\
\hline C. intermedia & $0 / 2$ & $0 / 2$ & $1 / 2$ & $0 / 2$ & $0 / 2$ & $0 / 2$ \\
\hline C. intermedia alba $\mathrm{x}$ C. trianaei alba & $0 / 1$ & $0 / 1$ & $0 / 1$ & $0 / 1$ & $0 / 1$ & $0 / 1$ \\
\hline C. labiata & $1 / 11$ & $0 / 13$ & $0 / 11$ & $0 / 13$ & $0 / 13$ & $0 / 13$ \\
\hline C. labiata alba & $0 / 1$ & $0 / 1$ & $0 / 1$ & $0 / 1$ & $0 / 1$ & $0 / 1$ \\
\hline C. labiata x C. labiata & $0 / 1$ & $0 / 1$ & $0 / 1$ & $0 / 1$ & $0 / 1$ & $0 / 1$ \\
\hline C. loddigesii & $0 / 2$ & $1 / 3$ & $0 / 2$ & $0 / 3$ & $0 / 3$ & $0 / 3$ \\
\hline
\end{tabular}




\begin{tabular}{|c|c|c|c|c|c|c|}
\hline \multirow[t]{2}{*}{ Amostra } & \multirow[b]{2}{*}{ ORSV } & \multicolumn{4}{|c|}{ Número de amostras positivas/amostras testadas } & \multirow[b]{2}{*}{ DsMV } \\
\hline & & CyMV & ORSV+CyMV & CMV & CyRSV & \\
\hline C. Marcilio Dias & $0 / 1$ & $0 / 1$ & $0 / 1$ & $0 / 1$ & $0 / 1$ & $0 / 1$ \\
\hline C. mossiae & - & $0 / 2$ & - & $0 / 2$ & $0 / 2$ & $0 / 2$ \\
\hline C. mossiae wagenerii & $0 / 1$ & $0 / 2$ & $0 / 1$ & $0 / 2$ & $0 / 2$ & $0 / 2$ \\
\hline \multicolumn{7}{|l|}{ C. mossiae wagenerii $\mathrm{x}$} \\
\hline C. mossiae wagenerii & $1 / 1$ & $0 / 1$ & $0 / 1$ & $0 / 1$ & $0 / 1$ & $0 / 1$ \\
\hline C. trianaei & $2 / 5$ & $0 / 10$ & $0 / 5$ & $0 / 10$ & $0 / 10$ & $0 / 10$ \\
\hline C. trianaei alba $\times$ C. trianaei alba & $0 / 2$ & $0 / 2$ & $0 / 2$ & $0 / 2$ & $0 / 2$ & $0 / 2$ \\
\hline C. warnerii & $1 / 1$ & $0 / 1$ & $0 / 1$ & $0 / 1$ & $0 / 1$ & $0 / 1$ \\
\hline \multicolumn{7}{|l|}{ (C. warnerii $\mathrm{x}$ C. mossiae) $\mathrm{x}$} \\
\hline C. mossiae & $0 / 1$ & $0 / 1$ & $0 / 1$ & $0 / 1$ & $0 / 1$ & $0 / 1$ \\
\hline Cirrhopetalum fascinator & $0 / 2$ & $0 / 2$ & $1 / 2$ & $0 / 2$ & $0 / 2$ & $0 / 2$ \\
\hline Coelogyne fimbriata & $0 / 1$ & $0 / 1$ & $0 / 1$ & $0 / 1$ & $0 / 1$ & $0 / 1$ \\
\hline C. flaccida & $0 / 1$ & $1 / 1$ & $0 / 1$ & $0 / 1$ & $0 / 1$ & $0 / 1$ \\
\hline C. sulphurea & $0 / 1$ & $0 / 1$ & $0 / 1$ & $0 / 1$ & $0 / 1$ & $0 / 1$ \\
\hline C. swaniana & $0 / 1$ & $1 / 1$ & $0 / 1$ & $0 / 1$ & $0 / 1$ & $0 / 1$ \\
\hline C. wettstemiana & $0 / 1$ & $0 / 1$ & $0 / 1$ & $0 / 1$ & $0 / 1$ & $0 / 1$ \\
\hline Coelogyne sp. & $0 / 8$ & $3 / 8$ & $0 / 8$ & $0 / 8$ & $0 / 8$ & $0 / 8$ \\
\hline Cymbidium aloefolium & $0 / 2$ & $0 / 2$ & $0 / 2$ & $0 / 2$ & $0 / 2$ & $0 / 2$ \\
\hline Dendrobium nobile & $0 / 7$ & $4 / 7$ & $0 / 7$ & $0 / 3$ & $0 / 3$ & $0 / 3$ \\
\hline D. regidum & $0 / 2$ & $0 / 2$ & $0 / 2$ & $0 / 2$ & $0 / 2$ & $0 / 2$ \\
\hline$D$. Utopia Messenger $\mathrm{x} D$. Hagoromo & $0 / 1$ & $0 / 1$ & $0 / 1$ & $0 / 1$ & $0 / 1$ & $0 / 1$ \\
\hline Dendrochillum sp. & $0 / 1$ & $1 / 1$ & $0 / 1$ & $0 / 1$ & $0 / 1$ & $0 / 1$ \\
\hline Encyclia acuta & $0 / 4$ & $0 / 4$ & $0 / 4$ & $0 / 4$ & $0 / 4$ & $0 / 4$ \\
\hline E. advena & $0 / 6$ & $0 / 6$ & $0 / 6$ & $0 / 6$ & $0 / 6$ & $0 / 6$ \\
\hline E. bahiensis $\times$ E. radiata & $0 / 1$ & $0 / 1$ & $0 / 1$ & $0 / 1$ & $0 / 1$ & $0 / 1$ \\
\hline E. longifolia & $1 / 2$ & $0 / 2$ & $0 / 2$ & $0 / 2$ & $0 / 2$ & $0 / 2$ \\
\hline E. maderoi & $0 / 2$ & $0 / 2$ & $0 / 2$ & $0 / 2$ & $0 / 2$ & $0 / 2$ \\
\hline
\end{tabular}




\begin{tabular}{|c|c|c|c|c|c|c|}
\hline \multirow[t]{2}{*}{ Amostra } & \multirow[b]{2}{*}{ ORSV } & \multicolumn{4}{|c|}{ Número de amostras positivas/amostras testadas } & \multirow[b]{2}{*}{ DsMV } \\
\hline & & CyMV & ORSV+CyMV & CMV & CyRSV & \\
\hline E. variegatum & $0 / 3$ & $0 / 3$ & $0 / 3$ & $0 / 3$ & $0 / 3$ & $0 / 3$ \\
\hline Epidendrum anceps & $0 / 1$ & $0 / 1$ & $0 / 1$ & $0 / 1$ & $0 / 1$ & $0 / 1$ \\
\hline E. radicans $\times$ E. linearis & $0 / 1$ & $0 / 1$ & $0 / 1$ & $0 / 1$ & $0 / 1$ & $0 / 1$ \\
\hline Epidendrum híbrido & $0 / 12$ & $2 / 13$ & $0 / 12$ & $0 / 13$ & $0 / 13$ & $0 / 13$ \\
\hline Eria longbianensis & $0 / 1$ & $1 / 1$ & $0 / 1$ & $0 / 1$ & $0 / 1$ & $0 / 1$ \\
\hline E. stellata & $0 / 1$ & $1 / 1$ & $0 / 1$ & $0 / 1$ & $0 / 1$ & $0 / 1$ \\
\hline Eria sp. & $1 / 1$ & $0 / 1$ & $0 / 1$ & $0 / 1$ & $0 / 1$ & $0 / 1$ \\
\hline Jumellea sp. & $0 / 1$ & $0 / 1$ & $0 / 1$ & $0 / 1$ & $0 / 1$ & $0 / 1$ \\
\hline Laelia anceps & $0 / 1$ & $1 / 3$ & $0 / 1$ & $0 / 3$ & $0 / 3$ & $0 / 3$ \\
\hline L. briegerii & $0 / 1$ & $0 / 1$ & $0 / 1$ & $0 / 1$ & $0 / 1$ & $0 / 1$ \\
\hline L. briegerii $\times$ L. flava & $0 / 2$ & $0 / 2$ & $0 / 2$ & $0 / 2$ & $0 / 2$ & $0 / 2$ \\
\hline L. briegerii $\mathrm{x}$ L. tereticaulis & $0 / 1$ & $0 / 1$ & $0 / 1$ & $0 / 1$ & $0 / 1$ & $0 / 1$ \\
\hline L. caulescens & $0 / 5$ & $0 / 5$ & $0 / 5$ & $0 / 5$ & $0 / 5$ & $0 / 5$ \\
\hline L. caulescens $\times$ L. caulescens & $0 / 1$ & $0 / 1$ & $0 / 1$ & $0 / 1$ & $0 / 1$ & $0 / 1$ \\
\hline L. caulescens $\times$ L. gloedeniana & $0 / 1$ & $0 / 1$ & $0 / 1$ & $0 / 1$ & $0 / 1$ & $0 / 1$ \\
\hline L. cinnabarina $\times$ L. esalqueana & $0 / 2$ & $0 / 2$ & $0 / 2$ & $0 / 2$ & $0 / 2$ & $0 / 2$ \\
\hline L. crispa & - & $0 / 4$ & - & $0 / 4$ & $0 / 4$ & $0 / 4$ \\
\hline L. crispilabia & $0 / 5$ & $0 / 5$ & $0 / 5$ & $0 / 5$ & $0 / 5$ & $0 / 5$ \\
\hline L. crispata & $0 / 1$ & $1 / 1$ & $0 / 1$ & $0 / 1$ & $0 / 1$ & $0 / 1$ \\
\hline L. esalqueana & $0 / 2$ & $0 / 2$ & $0 / 2$ & $0 / 2$ & $0 / 2$ & $0 / 2$ \\
\hline L. flava & $0 / 11$ & $0 / 11$ & $0 / 11$ & $0 / 11$ & $0 / 11$ & $0 / 11$ \\
\hline L. flava $x$ L. anceps & $0 / 1$ & $0 / 1$ & $0 / 1$ & $0 / 1$ & $0 / 1$ & $0 / 1$ \\
\hline L. flava $\times$ L. caulescens & $0 / 1$ & $0 / 1$ & $0 / 1$ & $0 / 1$ & $0 / 1$ & $0 / 1$ \\
\hline L. flava $\times$ L. crispata & $0 / 1$ & $0 / 1$ & $0 / 1$ & $0 / 1$ & $0 / 1$ & $0 / 1$ \\
\hline L. flava $\times$ L. grandis & $1 / 1$ & $0 / 1$ & $0 / 1$ & $0 / 1$ & $0 / 1$ & $0 / 1$ \\
\hline L. gloedeniana & $0 / 8$ & $0 / 8$ & $0 / 8$ & $0 / 8$ & $0 / 8$ & $0 / 8$ \\
\hline L. gloedeniana $\times$ L. crispilabia & $0 / 2$ & $0 / 2$ & $0 / 2$ & $0 / 2$ & $0 / 2$ & $0 / 2$ \\
\hline
\end{tabular}




\begin{tabular}{|c|c|c|c|c|c|c|}
\hline \multirow[t]{2}{*}{ Amostra } & \multirow[b]{2}{*}{ ORSV } & \multicolumn{4}{|c|}{ Número de amostras positivas/amostras testadas } & \multirow[b]{2}{*}{ DsMV } \\
\hline & & CyMV & ORSV+CyMV & CMV & CyRSV & \\
\hline L. grandis & $0 / 3$ & $0 / 3$ & $0 / 3$ & $0 / 3$ & $0 / 3$ & $0 / 3$ \\
\hline L. harpophyllax L. flava & $1 / 1$ & $0 / 1$ & $0 / 1$ & $0 / 1$ & $0 / 1$ & $0 / 1$ \\
\hline L. jongheana & - & $0 / 1$ & - & $0 / 1$ & $0 / 1$ & $0 / 1$ \\
\hline L. lucasiana x L. flava & $0 / 2$ & $0 / 2$ & $0 / 2$ & $0 / 2$ & $0 / 2$ & $0 / 2$ \\
\hline L. longipes & $0 / 1$ & $0 / 1$ & $0 / 1$ & $0 / 1$ & $0 / 1$ & $0 / 1$ \\
\hline L. longipes $\mathrm{x}$ L. flava & $0 / 1$ & $0 / 1$ & $0 / 1$ & $0 / 1$ & $0 / 1$ & $0 / 1$ \\
\hline L. millerii & $0 / 6$ & $0 / 6$ & $0 / 6$ & $0 / 6$ & $0 / 6$ & $0 / 6$ \\
\hline L. millerii $\mathrm{x}$ L. caulescens & $0 / 1$ & $0 / 1$ & $0 / 1$ & $0 / 1$ & $0 / 1$ & $0 / 1$ \\
\hline L. mixta $\times$ L. cinnabarina & $0 / 1$ & $0 / 1$ & $0 / 1$ & $0 / 1$ & $0 / 1$ & $0 / 1$ \\
\hline L. mixta $x$ L. crispilabia & $0 / 1$ & $0 / 1$ & $0 / 1$ & $0 / 1$ & $0 / 1$ & $0 / 1$ \\
\hline L. ostermayer & $0 / 1$ & $0 / 1$ & $0 / 1$ & $0 / 1$ & $0 / 1$ & $0 / 1$ \\
\hline L. perrinii & - & $0 / 6$ & - & $0 / 6$ & $0 / 6$ & $0 / 6$ \\
\hline L. pumila & $0 / 1$ & $0 / 4$ & $0 / 1$ & $0 / 4$ & $0 / 4$ & $0 / 4$ \\
\hline L. purpurata & $1 / 2$ & $0 / 5$ & $0 / 2$ & $0 / 5$ & $0 / 5$ & $0 / 5$ \\
\hline L. purpurata $\times$ L. cinnabarina & $0 / 2$ & $0 / 2$ & $0 / 2$ & $0 / 2$ & $0 / 2$ & $0 / 2$ \\
\hline L. purpurata alba $\times$ carnea $\times$ alba & $0 / 1$ & $0 / 1$ & $0 / 1$ & $0 / 1$ & $0 / 1$ & $0 / 1$ \\
\hline L. purpurata alba $\mathrm{x}$ carnea $\mathrm{x}$ carnea & $0 / 2$ & $0 / 2$ & $0 / 2$ & $0 / 2$ & $0 / 2$ & $0 / 2$ \\
\hline L. purpurata winkhauseri & $0 / 1$ & $1 / 1$ & $0 / 1$ & $0 / 1$ & $0 / 1$ & $0 / 1$ \\
\hline L. rupestris & $0 / 7$ & $0 / 7$ & $0 / 7$ & $0 / 7$ & $0 / 7$ & $0 / 7$ \\
\hline L. rupestris $\mathrm{x}$ L. flava & $0 / 1$ & $0 / 1$ & $0 / 1$ & $0 / 1$ & $0 / 1$ & $0 / 1$ \\
\hline L. tenebrosa & $2 / 2$ & $0 / 2$ & $0 / 2$ & $0 / 2$ & $0 / 2$ & $0 / 2$ \\
\hline Laelia sp. & $0 / 4$ & $0 / 4$ & $0 / 4$ & $0 / 4$ & $0 / 4$ & $0 / 4$ \\
\hline Liparis longipes & $0 / 1$ & $0 / 1$ & $0 / 1$ & $0 / 1$ & $0 / 1$ & $0 / 1$ \\
\hline Maxillaria sp. & $0 / 2$ & $0 / 2$ & $0 / 2$ & $0 / 2$ & $0 / 2$ & $0 / 2$ \\
\hline Megaclinium minutum & $0 / 1$ & $0 / 1$ & $0 / 1$ & $0 / 1$ & $0 / 1$ & $0 / 1$ \\
\hline Megaclinium sp. & $0 / 1$ & $0 / 1$ & $0 / 1$ & $0 / 1$ & $0 / 1$ & $0 / 1$ \\
\hline Miltonia candida $\times$ M. clowesii & $0 / 3$ & $0 / 3$ & $0 / 3$ & $0 / 3$ & $0 / 3$ & $0 / 3$ \\
\hline
\end{tabular}




\begin{tabular}{|c|c|c|c|c|c|c|}
\hline \multirow[t]{2}{*}{ Amostra } & \multirow[b]{2}{*}{ ORSV } & \multicolumn{4}{|c|}{ Número de amostras positivas/amostras testadas } & \multirow[b]{2}{*}{ DsMV } \\
\hline & & CyMV & ORSV+CyMV & CMV & CyRSV & \\
\hline M. candida $\times$ M. regnelii & $0 / 1$ & $0 / 1$ & $0 / 1$ & $0 / 1$ & $0 / 1$ & $0 / 1$ \\
\hline M. flavescens & $0 / 1$ & $1 / 1$ & $0 / 1$ & $0 / 1$ & $0 / 1$ & $0 / 1$ \\
\hline Octomeria grandiflora & $0 / 2$ & $0 / 2$ & $0 / 2$ & $0 / 2$ & $0 / 2$ & $0 / 2$ \\
\hline Odontoglossum sp. & $0 / 3$ & $0 / 3$ & $0 / 3$ & $0 / 3$ & $0 / 3$ & $0 / 3$ \\
\hline Oncidium advena & $0 / 1$ & $0 / 1$ & $0 / 1$ & $0 / 1$ & $0 / 1$ & $0 / 1$ \\
\hline$O$. altissimum & $1 / 1$ & $0 / 1$ & $0 / 1$ & $0 / 1$ & $0 / 1$ & $0 / 1$ \\
\hline O. warmingii & $0 / 1$ & $1 / 1$ & $0 / 1$ & $0 / 1$ & $0 / 1$ & $0 / 1$ \\
\hline Oncidium sp. & $0 / 1$ & $0 / 1$ & $0 / 1$ & $0 / 1$ & $0 / 1$ & $0 / 1$ \\
\hline Phaius grandifolius & $0 / 1$ & $0 / 1$ & $1 / 1$ & $0 / 1$ & $0 / 1$ & $0 / 1$ \\
\hline Pleurothallis pluriracemosa & $0 / 3$ & $0 / 3$ & $0 / 3$ & $0 / 3$ & $0 / 3$ & $0 / 3$ \\
\hline Pleurothallis sp. & $0 / 4$ & $0 / 4$ & $0 / 4$ & $0 / 4$ & $0 / 4$ & $0 / 4$ \\
\hline Ponera striata & $0 / 1$ & $0 / 1$ & $0 / 1$ & $0 / 1$ & $0 / 1$ & $0 / 1$ \\
\hline Sobralia sp. & $0 / 1$ & $0 / 1$ & $0 / 1$ & $0 / 1$ & $0 / 1$ & $0 / 1$ \\
\hline Trigonidium sp. & $0 / 2$ & $0 / 2$ & $0 / 2$ & $0 / 2$ & $0 / 2$ & $0 / 2$ \\
\hline Xylobium sp. & $1 / 1$ & $0 / 1$ & $0 / 1$ & $0 / 1$ & $0 / 1$ & $0 / 1$ \\
\hline \multicolumn{7}{|l|}{ Hóbridos intergenéricos } \\
\hline Brassia moreliana $\times$ Miltonia regnelii & $0 / 1$ & $0 / 1$ & $0 / 1$ & $0 / 1$ & $0 / 1$ & $0 / 1$ \\
\hline C. amethystoglossa $\times$ L. crispilabia & $0 / 1$ & $0 / 1$ & $0 / 1$ & $0 / 1$ & $0 / 1$ & $0 / 1$ \\
\hline C. bicolor $\mathrm{x}$ L. harpophylla & $1 / 1$ & $0 / 1$ & $0 / 1$ & $0 / 1$ & $0 / 1$ & $0 / 1$ \\
\hline C.gigas $\mathrm{x}$ L.cinnabarina & $1 / 1$ & $0 / 1$ & $0 / 1$ & $0 / 1$ & $0 / 1$ & $0 / 1$ \\
\hline C. guttata guttata $\times$ L. cinnabarina & $1 / 1$ & $0 / 1$ & $0 / 1$ & $0 / 1$ & $0 / 1$ & $0 / 1$ \\
\hline C. harrisoniana $\mathrm{x}$ L. crispilabia & $0 / 1$ & $0 / 1$ & $0 / 1$ & $0 / 1$ & $0 / 1$ & $0 / 1$ \\
\hline C. harrisoniana $\mathrm{x}$ L. rupestris & $1 / 1$ & $0 / 1$ & $0 / 1$ & $0 / 1$ & $0 / 1$ & $0 / 1$ \\
\hline C. intermedia $\times$ L. harpophylla & $0 / 1$ & $0 / 1$ & $0 / 1$ & $0 / 1$ & $0 / 1$ & $0 / 1$ \\
\hline C. labiata $\times$ L. cinnabarina & $0 / 1$ & $0 / 1$ & $0 / 1$ & $0 / 1$ & $0 / 1$ & $0 / 1$ \\
\hline C. skinerii $\mathrm{x}$ Rhyncholaelia ${ }^{*}$ glauca & $1 / 1$ & $0 / 1$ & $0 / 1$ & $0 / 1$ & $0 / 1$ & $0 / 1$ \\
\hline
\end{tabular}

* Gêneros que não ocorrem naturalmente 


\begin{tabular}{|c|c|c|c|c|c|c|}
\hline \multirow[t]{2}{*}{ Amostra } & \multirow[b]{2}{*}{ ORSV } & \multicolumn{4}{|c|}{ Número de amostras positivas/amostras testadas } & \multirow[b]{2}{*}{ DsMV } \\
\hline & & CyMV & ORSV+CyMV & CMV & CyRSV & \\
\hline C. skinerii $\mathrm{x}$ L. caulescens & $0 / 1$ & $0 / 1$ & $0 / 1$ & $0 / 1$ & $0 / 1$ & $0 / 1$ \\
\hline C. warnerii $\mathrm{x}$ L. cinnabarina & $1 / 1$ & $0 / 1$ & $0 / 1$ & $0 / 1$ & $0 / 1$ & $0 / 1$ \\
\hline L. caulescens $\mathrm{x}$ C. intermedia & $0 / 1$ & $0 / 1$ & $0 / 1$ & $0 / 1$ & $0 / 1$ & $0 / 1$ \\
\hline L. cinnabarina x Brassavola acutata & $0 / 1$ & $0 / 1$ & $0 / 1$ & $0 / 1$ & $0 / 1$ & $0 / 1$ \\
\hline L. cinnabarina $\times$ C. bicolor & $0 / 2$ & $0 / 2$ & $0 / 2$ & $0 / 2$ & $0 / 2$ & $0 / 2$ \\
\hline L. cinnabarina $\times$ C. percivaliana & $0 / 1$ & $0 / 1$ & $0 / 1$ & $0 / 1$ & $0 / 1$ & $0 / 1$ \\
\hline L. cinnabarina $\times$ C. schroderae & $1 / 1$ & $0 / 1$ & $0 / 1$ & $0 / 1$ & $0 / 1$ & $0 / 1$ \\
\hline \multicolumn{7}{|l|}{ L. cinnabarina $\mathrm{x}$} \\
\hline Schomburgkia superbiens & $0 / 1$ & $0 / 1$ & $0 / 1$ & $0 / 1$ & $0 / 1$ & $0 / 1$ \\
\hline L. crispa alba $\times$ C. trianaei alba & $0 / 1$ & $0 / 1$ & $0 / 1$ & $0 / 1$ & $0 / 1$ & $0 / 1$ \\
\hline L. flava x C. bicolor & $0 / 1$ & $0 / 1$ & $0 / 1$ & $0 / 1$ & $0 / 1$ & $0 / 1$ \\
\hline L. perrinii $\times$ C. dowiana 'rosita' & $0 / 1$ & $1 / 1$ & $0 / 1$ & $0 / 1$ & $0 / 1$ & $0 / 1$ \\
\hline L. tereticaulis $\times$ C. schofeldiana & $0 / 1$ & $0 / 1$ & $0 / 1$ & $0 / 1$ & $0 / 1$ & $0 / 1$ \\
\hline \multicolumn{7}{|l|}{ Oncidium flexuosum $\mathrm{x}$} \\
\hline Rodriguezia secunda & $0 / 1$ & $0 / 1$ & $0 / 1$ & $0 / 1$ & $0 / 1$ & $0 / 1$ \\
\hline Não identificadas & $0 / 7$ & $0 / 7$ & $0 / 7$ & $0 / 7$ & $0 / 7$ & $0 / 7$ \\
\hline Total & $23 / 282$ & $25 / 315$ & $8 / 282$ & $0 / 311$ & $0 / 311$ & $0 / 311$ \\
\hline
\end{tabular}

